\title{
Linking Arms Together: Multicultural Constitutionalism in a North American Indigenous Vision of Law and Peace
}

\author{
Robert A. Williams, Jr. $\dagger$
}

\section{INTRODUCTION: The ENCOUNTER AT THREe RIVERS}

\section{A. Kiotseaeton's Message of Peace}

In July of 1645, an Iroquois chief named Kiotseaeton approached the French colonial settlement at Three Rivers, New France, Canada, in a small boat. $^{1} \mathrm{He}$ was accompanied by two other Iroquois ambassadors and a Frenchman, Guillaume Cousture. Cousture had been taken hostage three years earlier in the Iroquois' long-running war with the French and the Canadian tribes over control of the immensely valuable colonial fur trade of eastern North America. According to Father Barthelemy Vimont, a French Jesuit priest who chronicled this early Encounter era diplomatic meeting, Kiotseaeton, upon landing his boat and seeing the French and their allied tribes hastening to the bank of the river, stood up in the bow and motioned with his hand for silence. "[H]igh in stature" and "almost completely cov-

Copyright (C) 1994 California Law Review, Inc.

$\dagger$ Professor of Law and American Indian Studies, University of Arizona. J.D. 1980, Harvard Law School. Member, Lumbee Indian Tribe of North Carolina.

I am grateful to the faculty members, students, and staff of the Yale Law School community for their helpful responses to an earlier version of this Article, delivered at the Law School as the James Thomas Lecture. I would also like to thank James Anaya, Milner Ball, and the participants in the faculty workshop at the UCLA School of Law for their helpful comments on an earlier version of this Article, and JoAnn DiGiulio who provided invaluable help as my research assistant for this Article.

I especially am grateful to the John D. and Catherine T. MacArthur Foundation and the National Endowment for the Humanities for their support of my research project on historical and contemporary North American indigenous visions of international law and peace, of which this Article is a part.

1. Kiotseaeton's embassy and the treaty councils of 1645 conducted at Three Rivers are reported in 27 The Jesutr Rezattons and Allied Documents: Travels and Explorations of the Jesuit Missionaries in New France, 1610-1791, at 247-305 (Reuben G. Thwaites ed., 1898) [hereinafter Jesuit Relations].

My discussion of the Three Rivers treaty councils of 1645 relies primarily on the account recorded by Father Barthelemy Vimont which was reprinted in THE HisToRy AND CULTURE of IROQuOIS Diplomacy 127-53 (Francis Jennings et al, eds., 1985) [hereinafter IROQuors DiplomaCY], from which all quotes are taken. The text was based on "the proceedings recorded by Father Barthelemy Vimont, S.J., of the 'Treaty of Peace Between the French, Iroquois, and other Nations.' Originally written in French and Latin, the text was translated into English and published in" Jesuit Relations, supra note 1, and was reprinted in IroQuors Diplomacy, supra. Id. at 137. 
ered with Porcelain beads," the "[b]arbarian," as Father Vimont described Kiotseaeton, cried out:

My Brothers, I have left my country to come and see you. At last I have reached your land. I was told, on my departure, that I was going to seek death, and that I would never again see my country. But I have willingly exposed myself for the good of peace. I come therefore to enter into the designs of the French, of the Hurons, and of the Alguonquins. I come to make known to you the thoughts of all my country. ${ }^{2}$

\section{B. The Iroquois Vision of Achieving Law and Peace in a Multicultural World ${ }^{3}$}

How do different peoples, with radically divergent cultural backgrounds, languages, value systems and traditions, achieve peace and accom-

2. Iroquois Diplomacy, supra note I, at 137-39. Kiotseaeton's embassy to the French at Thrce Rivers is discussed and analyzed in more detail infra Part $\mathbf{I}$.

3. The primary and secondary literature on Iroquois traditions of law and peace is voluminous. The major sources on which I have relied throughout this Article include: RICHARD AQUILA, THE Iroquois Restoration (1983); 1 Cadwallader Colden, The History of the Five Indian Nations of Canada (AMS Press, Inc., photo. reprint 1973) (1922); Barbara Graymont, The Iroquois in the american Revolution (I972); George T. Hunt, The Wars of the Iroquois: A Study in Intertribal Trade Relations (1940); Wilbur R. Jacobs, Diplomacy and Indian Gifts: AngloFrench Rivalry Along the OHIo and Northwest Frontters, 1748-1763 (1950); Francis Jenninos, The Ambiguous Iroquois Empire (I984) [hereinafter Jennings, The Ambiouous Iroquois Empire]; Francis Jennings, Empire of Fortune: Crowns, Colonies, and Tribes in the Seven Years War in America (1988) [hereinafter Jenninos, Empire of Fortune]; Francis Jenninos, The Invasion of America: Indians, Colonialism, and the Cant of Conquest (1975) [hereinaftcr Jennings, Tue INVAsion of America]; Dorothy V. Jones, License for EMpire (1982); 2 Joseph F. LAfitau, Customs of the American Indians Compared with the Customs of Primitive Times (William N. Fenton \& Elizabeth L. Moore ed. \& trans., The Champlain Society 1977) (1724); 1 LEWIS H. MOROAN, League of the Ho-De-No SaU-NeE or Iroquois (Human Relations Area Files 1954) (1901); Georgiana C. Nammack, Fraud, Polmtics, and the Dispossession of the Indians: The Iroquois Land Frontier in the Colonial Period (1969); Arthur C. Parker, Parker on the Iroquois (William N. Fenton ed., 1968); Bruce G. Trigger, The Children of Aataentsic I: A History of the Huron People to 1660 (1976); Anthony F.C. Wallace, The Death and Rebirth of the Seneca (1972) [hereinafter Anthony Wallace, The Death and Rebirth of the Seneca]; Paul A.W. Wallace, The Whtte Roots of Peace (I946) [hereinafter Paul Wallace, The White Roots of Peace]; Stephen S. Webi, 1676: The End of American Independence (1984); William M. Beauchamp, Civil, Religious and Mourning Councils and Ceremonies of Adoption of the New York Indians, 1 I3 N.Y. St. Museum Bull. 341 (N.Y. St. Educ. Dep't I975) (1907); Documents Relative to the Colonial History of the State of New-York (E.B. O'Callaghan ed., 1856-87); 1 Early American Indian Documents, Treaties, and Laws, 1607-1789: Pennsylvania and Delaware Treaties, 1629-1737 (Alden T. Vaughan gen. ed. \& Donald H. Kent vol. ed., 1979); 2 EarLY American Indian Documents, Treaties, and Laws, 1607-1789: Pennsylvania Treaties 1737-1756 (Alden T. Vaughan gen. ed. \& Donald H. Kent vol. ed., 1984); Leroy V. Eid, The Ojibwa-Iroquois War: The War the Five Nations Did Not Win, 26 EthNOHISTORY 297 (1979); EXTENDINo the RafTERs: INTERdisciplinary Approaches to Iroquolan Studies (Michael K. Foster et al. eds., 1984) [hereinafter Extending the RAfTers]; William N. Fenton, An Iroquois Condolence Council for Installing Cayuga Chiefs in 1945, 36 J. WASH. ACAD. Sc1. 110 (1946); William N. Fenton, Northern Iroquoian Culture Patterns, in 15 HANDBOOK OF NORTH AMERICAN INDIANS: NORTHEAST 296-321 (William C. Sturtevant gen. ed. \& Bruce G. Trigger vol. ed., 1978) [hereinafter 15 HANDBOOK]; JEsurr Relations, supra note 1; The Iroquors Book of Rrtes (Horatio Hale ed., Univ. of Toronto Press 
modation with each other? To borrow the words of the seventeenth century "barbarian" diplomat, Kiotseaeton, how do we enter into the designs of strange and alien others, and make known to them the thoughts of our own country, racial or ethnic group, or religious sect?

In this Article, I explore how one group of North American indigenous peoples, the Five Confederated Tribes of the Iroquois, confronted the immensely difficult problems of intercultural communication and accommodation during the early Encounter era. ${ }^{4}$ The European invasion of North America in the seventeenth and eighteenth centuries left the continent's indigenous tribal peoples with hittle choice but to meet head-on the numer-

1963) (1883); The Livingston Indian Records, 1666-1723, (Lawrence H. Leder ed., 1956); Jay Miller, The Delaware as Women: A Symbolic Solution, 1 AM. ETHNoLocist 507 (1974); Daniel K. Richter, Rediscovered Links in the Covenant Chain: Previously Unpublished Transcripts of New York Indian Treaty Minutes, 1677-1691, 92 PROC. AM. ANTIQUARIAN Soc'y 45, 47-48 (1982) [hereinafter Richter, Rediscovered Links]; Daniel K. Richter, War and Culture: The Iroquois Experience, 40 WM. \& MARY Q. 528 (1983) [hereinafter Richter, War and Culture]; Elisabeth Tooker, The United States Constitution and the Iroquois League, 35 ETHNOHIsToRy 305 (1988); Anthony F.C. Wallace, Origins of Iroquois Neutrality: The Grand Settlement of 1701, 24 PA. Hist. 223 (1957) [hereinafter Anthony Wallace, Origins of Iroquois Neutrality]; Lawrence C. Wroth, The Indian Treaty as Literature, 17 Y ALE REv. 749 (1928).

4. For purposes of this Article, the North American Encounter era is understood as running from roughly the early sixteenth through late eighteenth centuries, the period during which, as Professor Stephen Comell describes,

Europe spun a web about the world, and in the process the world was remade. During those and subsequent years, various peoples, nations, and ideas would struggie within the grasp of that web. Some would flourish, some would disappear; but few would entirely escape the ever-expanding network of connections that made this world so very new.

Stephen Cornell, The Return of the Native: American Indian Polmical Resurgence 11 (1988). Comell divides this "incorporative process" of the Encounter era into six major periods, "distinguished by the prevalence in each of more or less distinct sets of economic and political relationships" between North American tribes and Euro-American society. Id. at 12.

In this Article, I focus primarily on North American Indian-specifically Iroquois-conceptions of multicultural constitutionalism which emerge in the treaty literature of the first of these periods, identified by Cornell as the "market period." Id. As demarcated by Comell, this early period of multicultural confrontation and encounter in North America, to which I refer as the early Encounter period, "lasted from shortiy after Indian-White contact into the last half of the eighteenth century. Its centerpiece was the fur trade of the eastem woodlands, which incorporated Indians, as producers of peltry, into a European market and, as potential allies, into the system of competitive trans-Atlantic European politics." Id.

Of all the major periods of Indian-White contact in North America, this period is unique in that Euro-Americans sought reciprocal trade with Indian tribes, rather than direct control of Indian tribal natural resources, which consisted primarily of land. As Wesley Craven explains, European colonizers in this early Encounter period relied heavily on the profits of trade, primarily in beaver and other furs, to underwrite their North American ventures. Wesley F. Craven, The Colonies in Transition, 1660 1713, at 112 (1968). Success and profit in early North American mercantile ventures depended largely on forging alliances with tribal trading partners. See CoRNel, supra, at 17.

Thus, during the early Encounter era, tribes were often treated in fact, if not wholly regarded in theory, as rough political, economic, and military equals by their European trading partners. In this unique period of increasing interdependence between the different cultural and racial groups engaged in trade, and in the politics of accommodation and conflict surrounding trade, North American indigenous peoples proclaimed their visions of law and peace in a language and in metaphors still largely uncorrupted, though not wholly uninfluenced, by the subsequent corrosive and pervasive effects of incorporation, increased Indian dependence, and Euro-American hegemony. 
ous challenges of creating and sustaining cooperative relationships and firm alliances with the newcomers to their lands. ${ }^{5}$ Particularly in the eastern half of North America, Indian tribes confronted a threatening and rapidly changing world of crisis and conflict. Military and political rivalries centered in the Old World escalated and intensified throughout the period, inexorably drawing in North American tribes on the frontiers of the major European colomal empires. Throughout much of the Encounter era, Indians were regarded as fair game for exploitation, conquest, and ultimately dispossession of their territorial and political independence by competing European powers in quest of expanding their empires in the New World. ${ }^{6}$

Indian peoples responded to this era of crisis in diverse ways. To prevent European encroachment on their territories and independence, tribes throughout eastern North America strengthened and renewed ancient political institutions, reinvigorated old alliances and tribal confederacies, and in many instances sought to "link arms together" with European newcomers through treaties negotiated according to indigenous North American visions of law and peace in a multicultural world. ${ }^{7}$

5. The multi-volume Jesurr Relations, supra note 1 , is a rich ethnographic source of the cfforts of North American indigenous peoples to accommodate and form alliances with Europeans in the early Encounter era. The literature on Indian-White relations in the colonial era in general is voluminous, and a wealth of ethnographic descriptive materials exists on North American indigenous peoples' visions of law and peace. For the Iroquois and other eastern tribes, the reader is referred to the extcnsive bibliographies compiled in Elisabeth TOOKER, The Indians OF the Northeast: A Critical Bibliography (1978); Extending the Rafters, supta note 3, at 373-417; Iroquois Diplomacy, supra note 1, at 257-73.

Primary treaty documents of the colonial era are compiled in a number of sources, providing the reader with a wide sampling of North American indigenous peoples' treaty diplomacy and practices. Sources on which I have relied in my research on North American indigenous visions of law and peace, both in general and for this Article, include: 1 COLDEN, supra note 3; INDIAN TREATIES, PRINTED BY Benjamin Frankin, 1736-1762 (Historical Soc'y of Phila. 1938); Documents Relative to the Colonial. History of the State of New-YoRk, supta note 3; EARLy AMERICAN Indian Documents, Treaties, and Laws, 1607-1789, supra note 3; The Documentary History of THE STATE OF NBWYORK (E.B. O'Callaghan ed., 1850-51); THE LIVINGSTON INDIAN RECORDS: 1666-1723, supra note 3.

6. See, e.g., Cornell, supra note 4, at 12, 25-28 (discussing Europeans' use of Indian forced labor). See generally Douglas E. Leach, Colonial Indian Wars, in 4 HANDBOOK OF NORTH AMERJCAN INDIANS 128-43 (William C. Sturtevant gen. ed. \& Wilcomb E. Washburn vol. ed., 1988) [hereinafter 4 HANDBOOK] (ehronicling conflicts often arising from European displacement of Indians).

7. On the ubiquity of the concept of "linking arms together" in colonial era trcaty litcrature, see infra Part 1. On the Indian treaty as a distinct genus of American literature, created during a period of intense intercultural conflict and accommodation, see the classic essay by Lawrence $\mathrm{C}$. Wroth, The Indian Treaty As Literature, supra note 3. Surveying the distinct themes and metaphors of Indian diplomats cited throughout the colonial era treaty literature, Wroth wrote:

I am not ... eoncerned here with the self-interest of both sides that the Treaties revcal but with their importance as a neglected literary type that arose without conscious artistic design from the conflict of two distinct civilizations on the same soil-a type in which one reads the passion, the greed, and the love of life of hard-living men brought into close relationship without parallel conditions in the history of either race to guide its conduct. In it are displaycd certain raw human emotions: on the part of the Indians the fear of extinction, the desire to keep what the hand holds, the love of life, of ease and security. Seething in the same pot with these were the white man's passion to acquire and till the land, to build, to fill the left hand with more and more of the stuff that the right hand has grasped. All this is in the Indian Treaties, and in dramatic form. I wish that some teacher of history had poured for me this 
The early Encounter era period was a time of adaptation to radically new circumstances for Europeans as well. Nothing in their Old World experience had prepared them for the vast, hostile, and unyielding wilderness that, in the beginning of their colonizing enterprise, was America. ${ }^{8}$ During this period, Indian tribes enjoyed their greatest economic, military, and political power relative to their future European colonizers. Conflict, though a recurring theme in the period's historical literature, was not always the singular refrain of cultural relations during the Encounter. Accommodation of competing visions of the law and political arrangements

strong wine instead of the tea from Boston harbor with which the genuine thirst of my youth was insufficiently slaked, or that some teacher of literature had given me to read these vivid, picturesque records instead of saying that the colonial period had nothing to show of literary production except dull sermons, political tracts, prosy essays, and poems of invincible mediocrity. Id. at 766 .

8. European Enlightenınent era philosophers sucl as Thomas Hobbes, John Locke, and Adam Ferguson emphasized in their works that seventeenth century America and the Indian tribes which inhabited it approximated a state of nature in which natural law prevailed. Hobbes used the image of the Indian to illustrate his infamous assertion that the life of man in the original state of nature was "solitary, poore, nasty, brutish and short." "[T]he savage people in many places of America . . . have [virtually] no governinent at all; and live at this day in that brutish manner." ThOMAs HobBes, Leviathan 89 (Richard Tuck ed., 1991). See generally Robert F. BERKHOFER, THE WHITE MAN's INDIAN 16-22 (1979) (discussing the rhetoric and imagery used by whites to understand Indian peoples and their infiuence on Hobbes and Locke); Richard Ashcraft, Leviathan Triumphant: Thomas Hobbes and the Politics of Wild Men, in The Wild Man Within: An Image in Western Thought From the Renarssance to Romanticism 141 (Edward Dudley \& Maximillian E. Novak eds., 1972).

Locke wrote that "in many parts of America there was no government at all," and that "in the beginning all the world was America." JOHN LOCKE, THE SECOND TREATISE OF Government 52, 26 (J.W. Gough ed., 3d ed. 1966) (1690). Adam Ferguson, an eighteenth century Scottish Enlightenment thinker, wrote: "It is in [the Indians'] present condition that we are to behold, as in a mirror, the features of our progenitors." 4 HANDBOOK, supra note 6, at 541. These and other Enlightenment era philosophers believed that Europeans, in colonizing America, had been placed, in Locke's words, in that "state of perfect freedoun" in which all persons are at liberty "to order their actions and dispose of their possessions and persons as they think fit, within the bounds of the law of nature, without asking leave, or depending upon the will of any other man." LOCKE, supra, at 4. See also WILLLAM CronoN, Changes in the Land: Indians, Colonists, and the Ecology of New England 78-80 (1983) (discussing Locke's theories in the context of North American colonial settlement practices); ROBERT A. Williams, J., The American Indian in Western Legal Thought: The Discourses of Conquest 246-51 (1990) (discussing the influence of Locke's theories on the American Revolution and on American colonists' views of Indian land rights).

The intensity and high cost to Europeans, in terms of lost lives and capital, of intercultural conflict during the early Encounter era are amply illustrated by the major Indian wars of the period. In 1622, Opechancanough's "Inassacre" claimed the lives of nearly 350 of the 1,240 English colonists in the Virginia colony. This debilitating setback for the colony, which had been settled for more than a decade, was followed in 1644 by a second uprising organized by Opeohancanough. This conflict took the lives of more than 500 English Virginians. See Williams, supra, at 216-19. The Pequot War of 1637 required the fledgling colonies of Massaclusetts and Connecticut to undertake the expense of raising an army to fight off the threat to their survival. King Phillip's War of 1675-1676 caused a tremendous loss of lives on both sides throughout New England. See 4 HANDBOoK, supra note 6, at 133-35. See generally JENniNGS, THE INVASION OF AMERICA, supra note 3, at 177-313 for a thorough analysis and recounting of the seventeenth century New England Indian Wars. 


\section{is also an important theme, too often overlooked by historians of the Encounter era. ${ }^{9}$}

9. The theme of multicultural accommodation and cooperation permeates the works of Professor Francis Jennings, which represent a singular contribution to our understanding of the North Ameriean Encounter era. My own research on North American indigenous visions of law and peace has been influenced greatly by the following works of Professor Jennings: JENNINGs, EMPIRE OF FORTUNE, supra note 3; Jennings, The Ambiguous Iroquois Empire, supra note 3; Jennings, The Invasion of AMERICA, supra note 3; Francis Jennings, Glory, Death, and Transfiguration: The Susquehannock Indians in the Seventeenth Century, 112 Proc. AM. PHu. Soc' $¥ 15$ (1968); Francis Jennings, Iroquois Alliances in American History, in IroQuors Diplomacy, supra note 1, at 37.

In his luminous and engaging scholarship, Professor Jennings has sought to revise the dominant paradigm of "[t]he typical picture of American Indians in our histories." Jennings, The Amaiguous IROQUOIs EMPIRE, supra note 3, at 367. That picture, as Jennings writes, presents Indians "as barriers to westward expansion of "civilization." Id. But as Jennings illustrates, this picture is so "narrowly anglicized in ethnocentrism" as to eliminate even Spain's northward expansion and France's movement north and south along the Mississippi Valley. Id.

It must be emphasized that civilization was not an exclusive monopoly of the British empire and its colonies; and it follows that the westward march of civilization, as portrayed in our histories, is a fantasy. Not surprisingly, its corollary of the Indian or "savage" barrier is equally absurd when the hot air is blown away to permit a view of the fact supported by evidence. Indian cooperation was the prime requisite for European penetration and colonization of the North American continent.

Id.

Jennings singles out the much revered and influential historian of the American colonial frontier, Francis Parkman, for criticism as a prime purveyor of the grossly distorted histories that painted "savage" Indians as a "barrier" to civilization. According to Jennings, the Iroquois were a favorite target of Parkman's scholarly malpractice. In one of Parkman's most famous works incorporated into the canon of American frontier history, Francis Parkman, The Conspiracy of Pontiac and the Indian War After the Conquest of Canada (Little Brown \& Co. 1909) (1851), Parkman, in Jennings' words, "delivered a gothically lurid tale of Iroquois ferocity and terrorism," containing "hardly a word of verifiable truth in the whole frenzied outcry." JENnings, The AMBiguous Iroquois EMPIRE, supra note 3 , at 18 \& n.22. Jennings describes Parkman as "a racist of the venomous type who did not hesitate to falsify his source materials to make them support his Social Darwinian preconceptions." Id. at 19.

Professor Jennings, and others, have convincingly documented Parkman's "professional misconduct." Id. at 19 n.24. See, e.g., Francis P. Jennings, A Vanishing Indian: Francis Parknian Versus His Sources, 87 PA. MAG. Hist. \& BIography 306 (1963); Howard H. Peckham, The Sources and Revisions of Parkman's Pontiac, 37 Papers Bibliographical Soc'x Am. 293 (1943). This revisionist assault suggests how woefully inadequate, as defined by contemporary professional scholarly standards, the typical picture of American Indians is. The more rigorous scholarly works of Jennings and other revisionists have illuminated the distorting role of ethnocentrism and prejudice in our perceptions of American Indian contributions to American history. See, e.g., Jennings, Amaiguous IROQUOIS EMPIRE, supra note 3, at 17-20.

This Article is an effort to further enrich our understanding of the ways by which some lndian peoples actively sought cooperation with Euro-Americans during the Encounter era. Most importantly, it does not implicitly or explicitly attempt to argue that its narrative of Encounter era events is representative of the efforts of all North American indigenous peoples dealing with European colonizing peoples. The Encounter era Iroquois, as I try to show, are culturally and historically unique. By examining the traces of a single seventeenth century example of an Indian-directed multicultural treaty with a European colonial power, I hope to illuminate one Indian vision of law and peace that counters the dominant image of all Indians as "savages." The accumulation and retelling of such examples, by scholars and storytellers without the prejudices of Parkman and others of prior generations, might eventually substantiate and afflrm Professor Jennings' provocative counter-thesis of the North American Encounter:

Despite the fascination of European observers and writers with the othemess of Indians, it was human similarity that created great institutions of commerce and politics through which Indians guided Europeans to the interior and collaborated in their exploitation of its vast resources. 
In most North American colonial histories, there is a period when certain Europeans and certain Indian peoples recognize each other roughly as economic, military, and pohtical equals. ${ }^{10}$ Europeans in such circumstances had no choice but to listen seriously to American Indians and their unique visions of law and peace proclaimed by the rituals and ceremonies of the indigenous diplomacy practiced in the forests of North America. In the hundreds of recorded negotiations, agreements, and other treaty documents ${ }^{11}$ of the forest diplomacy carried on throughout the Encounter era, Europeans can be found adapting to, compromising with, and sometimes even expressing their admiration for, Indian approaches and solutions to problems of human diversity and conflict on the North American colonial frontier.

Kiotseaeton's 1645 embassy to the French and their allied tribes of Canada at Three Rivers represents the European's first recorded encounter with the Iroquois vision of law and peace. Kiotseaeton's offer to "enter into the designs" of the French colony and its client tribes, and "to make known" the thoughts of his country, was, in fact, a formative event in the colonial history of the North American frontier. The League of the

Id. at 367-68.

10. See, e.g., CoRnell, supra note 4, at 23-24 (noting "a relationship between powers that began more or less as equals").

Interaction among the European powers in North America did not occur in a political vacuum.

Particularly in the seventeenth and eighteenth centuries and in some cases until after the

American Revolution, certain Indian nations, individually or in concert, were significant powers in their own right, effectively controlling both the hinterlands and the resources therein. Eager for European goods, they were also politically and economically shrewd, searching for the best prices for their furs and for support in their own affairs with other Indian nations. Both geographically and politically their opportunities were limited, and at times they were forced into alliances they might not otherwise have chosen. Nonetheless, their support was often critical in intra-European confiicts. They came to the Europeans, but the Europeans, equally, came to them. Thus the trade produced more than furs. Politics and pelts were intertwined; at one time or another, success or failure for the various European powers, whatever the object, depended substantially on Indian alliance.

Id. at 17 .

11. I follow Mary Druke's definition of the term "treaty documents":

The phrase "treaty documents" is used here as a blanket term for written records (articles of agreement and minutes or proceedings of councils), wampum belts, and oral tradition, all of which provide evidence of treaty negotiations in the seventeenth, eighteenth and early nineteenth centuries. In any given instance, the types of treaty documents in evidence must be distinguished and evaluated for interpretation of the agreements presumed to have been made.

Mary A. Druke, Iroquois Treaties: Common Forms, Varying Interpretations, in Iroquors Diplomacy, supra note 1 , at $85-86$.

Professor Daniel Richter has succinctly summarized the value of the Encounter era treaty documents in reconstructing Indian multicultural diplomatic theory and practice, and how the advantages outweigh the disadvantages of reliance on these unique texts.

Treaty minutes are, of course, valuable for the light they shed on murky issues of intercultural diplomacy. They are perhaps more significant, however, for the accounts of Indian speeches which they contain. Such records are fraught with problems: interpreters' linguistic skills are suspeet; clerks frequently tired of long Indian "harangues" and noted only what they considered to be high points; and deliberate falsification sometimes occurred. Nevertheless, in no other source did ethnocentric Euro-Americans preserve with less distortion a memoir of Indian thoughts, concerns, and interpretations of events.

Richter, Rediscovered Links, supra note 3, at 47-48. 
Iroquois, a five nation confederacy of tribes comprised of the Mohawks, Oneidas, Onondagas, Cayugas, and Senecas, was one of the most significant indigenous powers of the Encounter era. The Iroquois' traditional territories were situated in what is now upper New York state along the southern side of the St. Lawrence River and Lake Ontario. To their north and west on the opposite side of the St. Lawrence was French Canada; to their immediate south and east were Great Britain's Atlantic Coast colonies. The Iroquois, therefore, occupied a central position of power and place on the eastern North American frontier. They have been called the Romans of the New World by the Europeans, not only in appreciation of their considerable skills of forest diplomacy displayed in the treaty councils, ${ }^{12}$ but also in recognition of their military and political achievements in constructing their own mnlticultural "empire" which they called the Covenant Chain. ${ }^{13}$

12. Iroquois oratorical skill was oft-noted and compared to that of the Romans by European colonists throughout the Encounter era. Witham Marshe described the chief Iroquois speaker at the Treaty of Lancaster in 1774 as follows:

[W] hen he spoke, [he] was certainly the most graceful, as well as bold, that any person ever

saw .... [H]e was complimented by the Governor, who said, "that he would have made a good figure in the forum of old Rome." And Mr. Commissioner Jenings declarcd, "that he had never seen so just an action in any of the nost celebrated orators he had heard speak."

Witham Marshe, Journal of the Treaty Held with the Six Nations by the Commissioners of Maryland, and Other Provinces, at Lancaster, in Pennsylvania, June, 1744, reprinted in 7 CoLlections of THB MASSACHUSETTS HISTORICAL SOCIETY, FOR THE YEAR 1800, 171, 200 (1801). In a work widely read during the colonial period, Cadwallader Colden wrote: "The History of the Five Nations will readily shew, how far the ancient Roman Principles have been cultivated among them." I CoLDEN, supra note 3, at 5. DeWitt Climton carried on this tradition of celebrating the oratorical and political skills of the Iroquois, specifically calling them "The Romans of this Westem World." Daniel K. Ritcher \& James H. Merrell, Introduction to Beyond the Covenant Chain: The Iroquors AND Their Neiohbors in IndiAN NORTH AMERICA, 1600-1800, 5 (Daniel K. Richter \& James H. Merrell cds., 1987).

In his leading study on the structure and spirit of the League of the Iroquois, Lewis Henry Morgan invoked the ciceronian rhetorical idcal to explain the Iroquois' appreciation and development of oratorical skill:

The Indian has a quick and enthusiastic appreciation of eloquence. Highly inpulsive in his nature, and with passions untaught of restraint, he is strongly susceptible of its influence. By the cultivation and exercise of this capacity, was opened the pathway to distinction; and the chief or warrior gifted with its magical power could elevate himself as rapidly, as he who gained renown upon the war-path. With the Iroquois, as with the Romans, the two professions, oratory and arms, could establish men in the highest degree of personal consideration. To the ambitious Roman in the majestic days of the Republic, and to the proud Indian in his sylvan house, the two pursuits equally counmended themselves; and in one or the other alone, could either expect success.

MoRgan, supra note 3 , at 102.

13. The idea of the Iroquois as "empire" builders was popularized by Lewis Henry Morgan. Often called the founder of American ethnography, Morgan wrote that the Iroquois "achieved for theinselves a more remarkable civil organization, and acquired a higher degrce of influencc, than any other race of Indian lineage, except those of Mexico and Peru." MOROAN, supra note 3, at 3.

Professor Jennings suggests that the idea of an Iroquois "cmpire" of tribes, as Europcans understood that term in the eighteenth century, was a convenient "myth," concocted to bolster British territorial claims in North America. By virtue of its various treaty arrangements with the Iroquois, Britain frequently sought to claim any preemptive rights to the Iroquois einpire for itself as against competing French claims. See Jenninos, The Ambiguous IroquoIs Empire, supra note 3, at 10-24. "It was not the first, nor the last, example of creative history by diplomats, and it was swallowcd whole by generations of partisan historians." Id. at 11 . 
The Covenant Chain was the primary constitutional device utilized by Iroquois diplomats to survive amidst the contending forces of the European empire on the North American continent. ${ }^{14}$ The Chain concept assumes

What the Iroquois did have was the Covenant Chain; "a multiple alliance" binding, in Professor Jennings words, "tribes and colonies in a 'silver" chain of friendship." Id. at 149 (footnote omitted). The Chain concept figures prominently for the first time in Iroquois-English relations at a treaty conference held in 1677, at the conclusion of King Philip's War. The treaty conference was sponsored by New York's colonial governor, Edmund Andros, who had intervened in New England's Indian war by arming the Mohawks "to strike a decisive blow against King Philip and his allies." Id. at 148-49. The treaty conference was held at the insistence of New England's Puritan colonies so that they could "deal with the tribes themselves, face to face (under Andros's chaperonage), and ... each of the parties would be responsible for its own obligations. Such proceedings fitted well into Puritan notions of covenanting." Id. at 148. The Chain assunses prominence in the subsequent treaty literature as the principal constitutional mechanism by which the Iroquois and English sought to structure their multicultural alliances for the next century.

In 1689, the Mohawk chief Sachem Tahaiadoris explained The Chain's geographical scope as follows:

Brethren: You are come here to this Prefixed Place [Albany] which is by the Christians appointed to be the house of Treatty for all Publique Bussinesse with us the Five Nations, and doe Return you many thanks for your Renovacon of the Covenant chain which is not of Yron now as it was formerly, but of Pure Silver, in which chain are Included all there Majesties Subjects from the Sinnekes Countrey quite to the Eastward as fart as any Christian Subjects of our great king lives and from thence Southward all along New England quite to Virginia.

Id. at 145 (quoting Mohawk Chief Sachem Tahaiadoris, Sept. 23, 1689).

By the mid-eighteenth century, as English colonial officials relied more heavily upon the Iroquois alliance as a buffer to French imperial ambitions in North America, the Covenant Chain assumed mythical proportions in Iroquois-English relations. It was traced back to the first arrival of the English in New York by Sir William Johnson, without a doubt England's most important Indian-affairs official in the colonies. Johnson alluded to the Chain's antique origins in 1748, at the outbreak of the French and Indian War, in the following speech to the Iroquois Confederacy at Onondoga:

Brethren of the five Nations, I will begin upon a thing of a long standing, our first Brothership.... I found out some of the old Writings of our Forefathers which was thought to have been lost, and in this old valuable Record I find, that our first Friendship Commenced at the Arrival of the first great Canoe or Vessel at Albany, at which you were much surprized but finding what it contained pleased you so much, being Things for your Purpose ... you all Resolved to take the greatest care of that Vessel that nothing should hurt her Whereupon it was agreed to tye her fast with a great Rope to one of the largest Nut Trees on the Bank of the River. But on further Consideration in a fuller meeting it was thought safest, Fearing the Wind should blow down that Tree, to make a long Rope and tye her fast on Onondaga which was aecordingly done and the Rope put under your feet. That if anything hurt or touched said Vessel by the shaking of the Rope you might know it, and then agreed to rise all as one and see what the Matter was and whoever hurt the Vessel was to suffer. After this was agreed on and done you made an offer to the Governour to enter into a Band of Friendship with him and his People which he was so pleased at that he told you he would find a strong Silver Chain which would never break, slip, or Rust to bind you and him forever in Brothership together, and that your Warriours and ours should be as one Heart, One Head, one Blood \&ca.

Id. (quoting Sir Williain Johnson to the Six Nations, Onondaga, April 25, 1748).

Other sourees which discuss this unique multicultural alliance include STEPHEN S. WEBB, 1676: The End of American Independence 355-405 (1984), and Richard L. Haan, Covenant and Consensus: Iroquois and English, I676-I760, in Beyond the Covenant Chan, supra note 12, at 41. Haan's essay attempts to bring the Chain "into still sharper focus," and concludes that there were several "distinct" chains linking the Iroquois in alliance with different colonies and other indigenous peoples. Id. at 41-42. The "Covenant Chain," Haan states, was generally perceived by English colonists as "a multiple alliance binding on tribes and colonies." Id. (quoting JeNNINGS, THE AMBiguous Iroquors EMPIRE, supra note 3, at 149).

14. My use of "constitutional" in describing the Covenant Chain is intentional, and borrows from J.G.A. Pocock, who refers to "constitutional thought" as "thought about the forms and institutions of joint action between citizens." J.G.A. Pocock, The Machiaveluian MOMENT 99 (1975). Although the 
prominence in the treaty literature during the late seventeenth century as a multicultural alliance between the Five Nations of the Iroquois, including a varying number of their lesser tributary tribes of the Atlantic Coast region, and the mid-Atlantic English colonies, linked through a series of treaties and agreements regulating trade and military relationships. ${ }^{15}$ New York was the lead colony on the English side of the Chain, ${ }^{16}$ but the New England colonies, Pennsylvania, Maryland, and Virginia were also linked to the Iroquois through the Chain. ${ }^{17}$

A primary purpose of the Covenant Chain alliance was stated directly by the English imperial ministry in a report by the Board of Trade and Plantations to the House of Commons in 1702. The Chain, in the view of the Board, was necessary for "preserving the friendship of the Five Nations of Indians, which are a barrier between his Majesty's Plantations and [the French in] Canada, by treating them kindly, and shewing them a force constantly maintained . . . to protect them."18

From both the English and Iroquois perspective, the Covenant Chain was a relationship of trade and collective security, designed to counter the French-based commercial and military empire centered in Canada. But it was also much more than that. Grounded in Iroquois legal and political traditions prescribing the constitutional organization of multicultural alliances, the Covenant Chain enabled the Iroquois to demand, and for a not inconsiderable period of time during the Encounter era to receive, reciprocal treatment and respect as mutual partners in their alliance with the English colonies. ${ }^{19}$

Iroquois never reduced the Chain to a "written" constitution, as such, during the Encounter era it provided the forms and institutions of joint action between the Iroquois and English colonies. See Jennings, The Ambiguous Iroquors Empire, supra note 3, at 368. ("There was enough identifiable structure in the Chain to warrant being called a constitution-not in the American sense of one basic law, but rather as the British use that word to embrace a whole body of traditions, customs, and practiccs basic to the polity.").

15. See Jennings, The Ambiguous Iroquors Empire, supra note 3, at 372.

16. See id. at 369.

17. See id. at 370-74. The evidence indicates that Pennsylvania likely maintained what it regarded as a separate chain with the Iroquois, with a "fire" that bumed at Philadelphia, and not Albany. See id. at 315. For a discussion of Haan's conclusion that the Chain consisted of multiple alliances, see Haan, supra note 13.

18. Jennings, The Ambiguous Iroquois Empire, supra note 3, at 370 (footnote omitted).

19. Though "mutual" partners, this is not to say that the Iroquois were fully equal partners, at least according to how non-Iroquois might interpret the Covenant Chain.

Jennings stresses that both the English and the Iroquois regarded the Chain "as an instrument" to serve their own purposes. For the Iroquois, however, "their economic dependence on the intersocietal trade controlled by Europeans" placed real limits on their power, limits "largely determined by what services they could perform for the English." Id. at 373. Nonetheless, both sides to the Chain needed each other for their own purposes. The Chain served as a constitutional device for organizing the interests of the parties, and as Jennings notes, "the interests of all the parties coincided often enough, and mutual concessions were made frequently enough, to hold the rickety edifice more or less together for a century." Id. at 374. But see Haan, supra note 13, at 48 (discussing the refusal of both New York and the Senecas to aid the Five Nations against the French in the summer of 1684). 
The Covenant Chain has intrigued, and even inspired, recent historians of the North American Encounter, for there is seemingly nothing else quite like it reported in the treaty literature. ${ }^{20}$ Francis Jennings, who has written the leading study on the Covenant Chain ${ }^{21}$ and its role and function in what he has called "the Ambiguous Iroquois Empire," cites it as an "example of accommodation and cooperation between peoples of different ethnicity, different cultures, and different social and political structures."22 The Chain, as analyzed by Jennings, operated as a multicultural constitution in the Encounter era frontier by transcending notions of "tribe, state, and empire."23

As a constitution, the Chain was fundamentally a legal and political text, for both the English and the Iroquois were guided in their relations by its underlying principle of a continually renewed reciprocity of rights and duties. The Chain's imagery and netaphors-of two once-alien groups connected in an interdependent relationship of peace, solidarity, and trust-became the governing legal and political language of EnglishIroquois forest diplomacy for most of the Encounter era, and even into the Revolutionary era. ${ }^{24}$

20. Haan notes that research on the Chain has given us a "new appreciation of diplomacy's central importance in European-Indian relations," and has enriched our "understanding of the complexity" of those relations. Haan, supra note 13 , at 41 . Haan warns, however, that historians must be careful in attempting to gain a clearer understanding of the Chain. A closer study of the origins of Covenant Chain diplomacy, he argues, reveals "that the relationship between Iroquois and English, each with their own view of the way things ought to work, was still more ambiguous than we thought." Id. at 42 . Haan's point is that we really know very little about the Chain, and the more we learn the clearer it becomes that Iroquois thought on multicultural constitutional relationships differed substantially from European thought about such arrangements. Therefore, using such terms as "equal" and "unequal" to describe the Iroquois-English partnership under the Chain, see supra note 19, is not particularly useful for characterizing the Chain relationships, at least from the Iroquois point of view.

21. Jennings, The Ambiguous Iroquors Empire, supra note 3.

22. Id. at 374-75.

23. See id. at 375 . On the Covenant Chain's "unique" aspects, Jennings writes:

Perhaps anthropologists have been reluctant to recognize the Covenant Chain because it violates their theories as well as legal dicta. It does not fit an evolutionary scheme of any kind because it was unique. It does not fit well in the functional analysis of given cultures because it was bi-societal and bi-cultural. Some anthropologists are so addicted to synchronic studies (i.e., snapshots of a culture) that they have simply defined historical complexities out of bounds.

Id. at 39 .

24. See, e.g., Bruce E. Johansen, Forgotten Founders (1982) (arguing that the Iroquois played a major role in shaping both Franklin's ideas and the American revolution); Gregory Schaaf, From the Great Law of Peace to the Constitution of the United States: A Revision of America's Democratic Roots, 14 AM. IndiAN L. REv. 323, 324-31 (1989) (exploring evidence of Iroquoian influence on the U.S. Constitution). As an admitted newcomer and outsider to Iroquoian studies, I will avoid overt engagement in the often needlessly acrimonious debate about the degree of infiuence of Iroquois political ideas on the "Founders" of the United States and their drafting of this nation's Constitution. See, e.g., Donald A. Grinde JR., The Iroquois and the Founding of the American NAtion (1977); JACK M. Weatherford, Indian Givers: How tHe Indians of the AMERICAS TRANSFormed the WORLD (1988); Indian RoOTS OF AMERICAN DEMOCRACY (José Barreito ed., Akwe:kon Press, Cornell Univ. 1992) (1988); Michael Newman, Founding Feathers: The Iroquois and the Constitution, NEw Republic, Nov. 7, 1988, at 17-18; Tooker, supra note 3. Compare Schaaf, supra with Erik M. Jensen, The Imaginary Connection Between the Great Law of Peace and the United States 
Father Vimont's relation of the Treaty Council at Three Rivers contains the earliest set of detailed references in the treaty literature to the multicultural constitutional vision proclaimed by the later-articulated Covenant Chain alliance with England's North American colonies. At the time of the treaty council, the Iroquois had been engaged in a decade-long trade war with France and its client tribes in the St. Lawrence region for control of the valuable fur supply of eastern North America. Three Rivers was the first major reported effort by the Iroquois to establish a permanent peace and multicultural alliance with the French colonists and their allied Canadian tribes. ${ }^{25}$ The ultimate failure of this diplomatic initiative (the treaty eventually concluded by Kiotseaeton at Three Rivers in 1645 was effectively breached by the parties just three years later in 1648) led directly to the outbreak of what historians have called the Beaver Wars. This extended series of raids, attacks, and counter-attacks between the Iroquois and the French aligned with the Canadian tribes engulfed a large portion of the eastern North American frontier in vicious warfare for more than half a century. ${ }^{26}$ In response to the debilitating effects on its member tribes' pop-

Constitution: A Reply to Professor Schaaf, 15 AM. INDIAN L. Rev. 295, 295-98 (1990) (characterizing Schaaf's theory as "extreme," "unbelievable," and based on "fabricated history").

Even the Congress of the United States has weighed in on the historical controversy with a formal resolution acknowledging "the contribution of the Iroquois Confederacy of Nations to the development of the United States Constitution." H.R. Con. Res. 331, 100th Cong., 2d Sess. (1988); see also Iroquois Confederacy of Nations: Hearing Before the Select Comm. on Indian Affairs, 100th Cong., 1st Scss. (1987).

As this Article attempts to demonstrate, I regard the lroquois vision of law and peace found in the Encounter era treaty literature as meaningful and relevant to contemporary concems on issues of racial and cultural diversity and conflict precisely because Iroquois constitutional ideas on structuring multicultural relationships were so unlike anything brougbt by the Europeans to America, or implemented by them once they got here and acquired power over the continent. See generally Rennard Strickland, Genocide-at-Law: An Historic and Contemporary View of the Native American Experience, 34 KAN. L. REv. 713 (1986) (looking at the role of law in the historical and contemporary gcnocidal experience of North American natives); Robert A. Williams, Jr., Documents of Barbarism: The Contemporary Legacy of European Racism and Colonialism in the Narrative Traditions of Federal Indian Law, 31 ARIz. L. REv. 237 (1989) (comparing the early ninetecnth century Cherokee discourse of tribal sovereignty with the opposing legal discourse deployed by Removal era whites in response to Indian resistance to white hegemony).

25. See HuNr, supra note 3, at 69-79. Kiotseacton was actually representing only the Mohawks, for he could not bind the four other tribes of the Iroquois Confederacy without consulting them first. As Professor Hunt explains, Kiotseaeton made no effort to deceive the French on this point, who were told "plainly" by Kiotseaeton later during the treaty council to "beware of the uppcr nations [of the confederacy]." Id. at 79 n. 37. At the conclusion of the treaty couneil, Kiotseaeton only promised to make every effort to convince the other confederated tribes to enter into the peace with the French and their allied tribes of Canada. See id. Kiotseaeton's claim to speak "the thoughts of all my country," IroQuors DiplomacY, supra note 1, at 138, was, in the words of Hunt, "rhetorical and formulary, and was so understood by the French." HuNT, supra note 3, at 79 n.37.

26. See Hunt, supra note 3, at 85-86; Iroquols DiplomacY, supra note 1, at 131-32. Professor Hunt cites the broken treaty made by Kiotseaeton in 1645 as irretrievably setting in motion the chain of events leading to the half-century long Beaver Wars, which resulted in the virtual elimination of several major tribal groups as distinct cultural entities at the hands of the Iroquois. Professor Trigger views the treaty as providing only a temporary truce for the exchange of prisoners, see TRIGoER, supra notc 3, at $650-52$, but Trigger's account of Iroquois intentions has been criticized by Jennings. See JenNings, THB 
ulation numbers and to protect the territorial gains seized from the western tribes in the early decades of the Beaver Wars, the Iroquois Confederacy focused its attention on developing and strengthening its Covenant Chain alliance with the English colonies. ${ }^{27}$ In the process, as Professor Jennings notes, the Chain became "the primary instrunent for opening the transAppalachian West to Britisl colonization,"28 permitting Great Britain to frustrate and counter French penetration into the region. The culminating confrontation between British and French inuperial ambitions in North America in the eighteenth century - the French and Indian War-cannot be fully understood apart from an appreciation of the inportant role of the Englisl-Iroquois Covenant Chain alliance in the events leading up to that conflict. Major roots of the European imperial contest for control of North America trace back to the failed Treaty of Three Rivers in 1645 and the opposing French/Indian and English/Indian alliances that solidified in its wake. ${ }^{29}$

Thus, the treaty council at Three Rivers provides us with one of the earliest and most coniplete accounts of Iroquois diplomatic theory and practice at a time when this North American indigenous vision of law and peace was undergoing significant transformations and adaptation to the radically new experiences associated with colonizing Europeans. Even more saliently, the Treaty at Three Rivers provides insight into Iroquois constitutional thought concerning the appropriate forms and institutions of joint action and solidarity between diverse peoples that was later translated into the multicultural constitutionalism of the Covenant Chain. Much of the "language" and "vocabulary" of Iroquois political and legal discourse organized around the Covenant Chain of the late seventeenth century and beyond is, in fact, found recorded for the first time in the Encounter era treaty literature at Three Rivers in $1645 .^{30}$

AMBiguous IroQuoIs EMPIRE, supra note 3, at 93 n.4. My own interpretation of the primary documents and secondary sources situates the breach as a pivotal event in the Encounter era.

27. As explained by Haan:

By the end of King William's War [one of several European-Indian conflicts connected to the long-running Beaver Wars] in 1697, the Iroquois were not only suffering defeats in the west, they were also threatened by war parties entering Iroquoia itself. To cope with these setbacks, they requested more help from New York. In 1698 Iroquois negotiators gained (after some opposition from New York's govemor, Richard Coote, Earl of Bellomont) a promise to protect them from westem Indian, as well as French, military aggression. The record of these negotiations, printed for public consumption to enhance Bellomont's claims to control of the Five Nations, repeatedly refers to the renewal of the Silver Covenant Chain ....

Haan, supra note 13 , at 52 .

28. Jennings, The Ambiguous Iroquois Empire, supra note 3, at 368.

29. See Jennings, EMPIRE of Fortune, supra note 3, for a detailed discussion of the relation between the Covenant Chain alliance and the French and Indian War of 1748.

30. In studying political and legal discourse, as Professor Pocock has explained,

[t]he historian's first problem . . . is to identify the "language" or "vocabulary" with and within which the author [of a political utterance] operated, and to show how it functioned paradigmatically to prescribe what he might say and how he might say it. This task can more easily be imagined if we suppose ... that his society possessed a number of distinguishable 
Concededly, Kiotseaeton's offer to "link arms together' with the French and their allied Indian tribes at Three Rivers in 1645 ended in ultimate failure. But in our search for law and peace in today's multicultural world we can derive value from efforts to reconstruct this important moment in the history of North American indigenous and political thought. In Kiotseaeton's message of peace at Three Rivers we can locate the earliest recorded origins of a unique set of paradignis and institutions by which one group of North American indigenous peoples, the Iroquois, sought to achieve a relationship of interdependence, solidarity, and trust with a European-derived colonial power. These paradigms and institutionseventually applied successfully by the Iroquois in forming later Covenant Chain alliances-teach us that the challenge of achieving law and peace between the different peoples of North America traces back to our earliest multicultural encounters; they teach us that Indian peoples, as a matter of survival, have persistently formulated creative approaches to this challenge. Their successes, as well as their failures, therefore, may teach us a great deal about the process of how different peoples from radically divergent cultural backgrounds try to achieve peace and accommodation with each other. By examining a North American indigenous vision of law and peace, perhaps we may discover how different peoples can agree to link arms together today. ${ }^{31}$

idioms, diverse in both their cnltural origins and their linguistic functions, with which to discuss questions of politics-theological, legal, humanist, and so on.

J.G.A. Pocock, Polmics, Language and Time: Essays on Polmical Thought and History 25 (1971).

By identifying the symbols and idioms of the diplomatic "language" and "vocabulary" employed by Kiotseaeton at the Treaty of Three Rivers, and by demonstrating that their intellectual origins are sustained by ideas indigenous to pre-contact Iroquoian society and culture, I hope to engender a deeper respect and understanding for the complexity and richness of an Amcrican Indian legal and political language for achieving law and peace between different peoples. Returning to Professor Pocock:

If at this stage we are asked how we know the languages adumbrated really existed, or how wc recognize them when we see them, we should be able to reply empirically: that the languages in question are simply there, that they form individually recognizable patterns and styles, and that we get to know them by learning to speak then, to think in their patterns and styles until we know that we are speaking them and can predict in what directions speaking them is carrying us.

Id. at 26.

31. Professor Jennings' insights on this point are worth quoting at length:

The chronicler of accommodation has a great problem in trying to write fairly and objcctively because of the categories that govern our thinking. At bottom is the assumption of sidedness: issues are secn at first glimpse as matters of Our Side and Their Side. . . . Primitive assumptions of sidedness develop into artificial, polarized categories of definition: savagery vs. civilization, heathen vs. Christian, subject vs. sovereign; upper class vs. lower class; Red (or Black) vs. White; and so on. Opposition and confiict inhere in the catcgorics and in the attitudes so generated. In consequence, accommodation usually gets a bad press by being equated to capitulation or betrayal. Honor and glory are given to the heroes who stand staunch and fight hard for Our Side, whatever it happens to be. Compromisers become contemptible. ...

With our eyes fixed upon confiict between two sides, and our sympathies fixed upon one of them, we glory in triumphs and fail to see the benefits to be derived from cooperation, or at least accommodation, between those sides. It seems to me that historical scholarship can be most useful in our day by finding ways to avoid political and social confiicts that all-too- 
For indigenous peoples, reviving and reintegrating these discourses of law and peace in ways that respond meaningfully to a rapidly changing time of crises remains the critical challenge in their contemporary struggle for survival. ${ }^{32}$ Unearthing the archaeology of cross-cultural confrontations and accommodations may suggest new metaphors and new languages for better understanding and resolving this fundamental problem of indigenous peoples' survival in a multicultural world. ${ }^{33}$ From the non-Indian perspective, reexamining efforts made between the Indian and Europeans during the Encounter era to achieve and sustain relationships of interdependence and solidarity can spur the development of critical perspectives on visions of law and peace for our own multicultural world.

In Part I of this Article, I examine Iroquois Encounter era traditions of law and peace. Through these traditions the Iroquois established and maintained relations of interdependence, solidarity, and trust within their tribal confederacy. In this Part, the Iroquois Condolence Ceremony, the central ritual of Iroquois social life and culture, the Deganawidah Epic, the charter myth of the founding of the League, and the vision of the Great Peace are explained and analyzed in order to assess their role and function in extending and perpetuating relations of kinship, reciprocity, and goodwill between members of the League tribes. By promoting the creation of relationships of law and peace between once-alienated and differing groups of people, these traditions enabled the Iroquois to "link arms together" and thereby establish and maintain one of the most powerful tribal confederacies of the Encounter era.

Part II analyzes how Iroquois diplomats like Kiotseaeton adapted and translated these traditions into a multicultural constitutional vision for ordering relations between the differing peoples of the early Encounter era. This North American indigenous vision, whicl emerges in its most highly imagined and developed form as the Covenant Chain in the late seventeenth century treaty literature, sought accommodation and cooperation between diverse peoples by transcending notions of "tribe, state, and empire." 34 The

predictably become disasters. This cannot be done by smudging the facts; conflicts of interests and ideas must be portrayed faithfully, or necessary adjustments cannot be made seasonably. But means and devices to avoid such conflicts, or to resolve them with minimum damage, must be given their due. The need is to reject the assumption of inevitability.

Jennings, The Ambiguous Iroquois Empire, supra note 3, at 375.

32. See Robert A. Williams, Jr., Encounters on the Frontiers of Intemational Human Rights Law: Redefining the Terms of Indigenous Peoples' Survival in the World, I990 DukE L.J. 660, 680-83 (describing threats to indigenous peoples' survival and recent efforts to develop legal standards to protect their rights).

33. There is a growing movement and literature in the fields of international law and indigenous human rights devoted to the problem of developing new approaches to assure the cultural survival of the world's indigenous peoples. See, e.g., S. James Anaya, The Rights of Indigenous Peoples and International Law in Historical and Contemporary Perspective, 1989 HARv. Indian L. SYMP. 19I (I990); Richard Falk, The Rights of Peoples (In Particular Indigenous Peoples), in THE RIGHrs oF Peoples I7 (James Crawford ed., I988); Hurst Hannum, New Developments in Indigenous Rights, 28 VA. J. INT'L L. 649 (1988); Williams, supra note 32.

34. See Jennings, The Ambiguous Iroquois Empire, supra note 3, at 375. 
vision was to be achieved through recognition of the interdependency and need for solidarity shared by the various cultural groups that struggled for survival on the colonial frontier. Through frequent dialogue, sharing, reciprocal exchanges of gifts and goodwill, and the mutualization of interests and resources, different peoples could attain "one mind," and "link arms together" in a multicultural treaty relationship.

Part III, which concludes this Article, explores the commensurability of this North American indigenous vision of law and peace between different peoples with contemporary understandings of the problem of achieving human solidarity and accommodation. The writings of a diverse range of twentieth century theorists echo and reverberate central themes of the message of peace spoken by Kiotseaeton at the Treaty of Three Rivers. This final Part of the Article, therefore, seeks to suggest ways in which a North American indigenous vision of law and peace can speak directly to us today. As this Article suggests, the difficulties we confront in communicating with, and trusting in, different peoples are similar to those confronted by an Iroquois diplomat on the seventeenth century colonial frontier. In seeking solutions for these recurrent problems of human diversity and conflict, perhaps we can learn lessons of value from the teachings of a North American indigenous vision of law and peace. Perhaps we can learn how different peoples, who do not share the same language, value systems, or traditions, can agree to link arms together.

\section{I}

A People of Connections: The Iroquois Vision of Law and Peace

The Iroquois vision of law and peace, which guided League diplomats like Kiotseaeton in negotiating treaties with peoples outside the Confederacy, and which found its most elaborate form of expression in the later-developed Covenant Chain alliance with the English colonies, was part of a much larger set of values central to Iroquois society. The traditions and language expressing this unique system of values permeated and defined the political and cultural aspects of Iroquois life: familial, societal, and constitutional.

The Iroquois vision of law and peace was expressed most powerfully in rituals and ceremonies drawn from the Deganawidah epic, the central myth of the Iroquois League's origins. As we shall see, Kiotseaeton, in a very different setting, drew upon these sacred rituals to communicate his message of peace and alliance to the French and their allied tribes. While the French were most impressed with Kiotseaeton's performance of these rituals, ${ }^{35}$ they did not recognize that the "barbarian's" songs, dances, and

35. Father Vimont, whose relation represents the only recorded text of the treaty negotiations at Three Rivers, remarked: "Every one admitted that this man was impassioned and eloquent. . . . He sang some songs between his gifts; he danced for joy; in a word, he showed himself to be a very good Actor, 
stories echoed a sacred Iroquois tradition of law and peace long predating the Encounter era. To better understand this tradition, and Kiotseaeton's rehance upon it in dehvering his message of peace at Three Rivers, this Part of the Article examines the sacred traditions of the Iroquois Condolence Council and their pervasive impact on the Iroquois' political and cultural life.

\section{A. The Condolence Council}

Kiotseaeton's plaintive cry for peace at the banks of the French settlement at Three Rivers was part of a diplomatic language known to all forest diplomats who survived for any significant length of time. ${ }^{36}$ At the time of the Treaty of Three Rivers, the Iroquois had been engaged for nearly a decade in a fierce and bloody war over beaver furs and the connected trade with the French and the Canadian Indian tribes. Aware that the unannounced arrival of an Iroquois chief in seventeenth century French Canada could well precipitate an armed attack, Kiotseaeton likely intended his cautious entry at Three Rivers to serve a self-preserving function. But the plaintive cry "at the wood's edge" 37 served a much broader purpose in the traditions of forest diplomacy practiced by the League of the Iroquois. According to the Iroquois vision of law and peace, the inaugural greeting at the wood's edge evoked the ritualized sequences of the Condolence Council. In its bare essence, the Council was an Iroquois ceremony for condoling the loss of dead chiefs and installing new ones to the League's confederated Council of Fifty Chiefs. But the ritualized discourses of the Condolence ceremony also provided the paradigms for the complex patterns

for a man who has leamed but what nature has taught him, without rule and without precept." IRoQuois Diplomacy, supta note 1 , at 142.

36. See Anthony Wallace, The Death and Rebirth of the Seneca, supra note 3, at 43 (describing how Iroquois messengers arriving at an enemy village would call "in a loud voice: 'Listen to me! I have come to treat for peace with all the nations in these parts . . . "); see also William N. Fenton, Structure, Continuity, and Change in the Process of Iroquois Treaty Making [hereinafter Fenton, Iroquois Treaty Making], in IROQUOIS Diplomacy, supra note 1, at 3.

Negotiations began even during hostilities, usually through a neutral party. Prisoners might be sent home with presents, including wampum from the public treasury. An old man of reputation might accept the risk of "going with wampum belts to clear the road" and thus "take away the thorns and thistles" to smooth the way for ambassadors who take the path when their welcome is ascertained. Invariably the council chose for this role old men of known competence. The council then charged the ambassadors with public and secret propositions and rehearsed them. "As if the words were written, they are given instructions by their wampum belts or with little sticks of different designs which have different meanings," so that they might forget nothing and not exceed their instructions. Presents were provided from the public treasury. An escort of warriors was appointed to hunt and scout their flanks, and one of them was dispatched to give advance notice of their approach. This enabled the host nation to prepare. Arriving at the woodsedge, a mile or so from the village, the embassy halted and sent word in of their presence.

Id. at 23.

37. See Glossary of Figures of Speech in Iroquois Political Rhetoric, in Iroquors Diplomacy, supra note 1, at 115, 124 ("To be at the wood's edge... was a manner of announcing one's readiness to treat."). 
of exchange and reciprocation imbedded in the Iroquois' many multicultural alliances. ${ }^{38}$

The Condolence Council embodied the Iroquois tradition of the "Great Peace," and served to maintain and renew the "good thoughts" linking the five tribes of the Confederacy to each other. ${ }^{39}$ In Iroquois legal thought, the Great Peace was a natural state of communication, connection, solidarity and trust between all peoples, linking them together in reciprocating relations of trade, friendship and goodwill. For the Iroquois the exchange of good thoughts between alienated or differing cultural groups was the original and continuing basis of a mutual relationship of reciprocating rights and accommodating duties. Kiotseaeton's offer at Three Rivers-to enter into the designs of the French and their Canadian Indian allies and in turn to make known the thoughts of all his country-was, in fact, the basic treaty term offered by Iroquois diplomats to all the peoples invited to share in the Great Peace.

The Condolence Council ritual ${ }^{40}$ traditionally began with the arrival of Iroquois messengers from the condoling "Clearminded" village who declared their presence and peaceful intentions at the "wood's edge" of the

38. This Iroquois emphasis on connection to others as a value to be pursued in and of itself is stressed by a number of scholars who have studied Iroquois treaty council protocol. See, e.g., Fenton, Iroquois Treaty Making, supra note 36, at 18-21. Fenton describes the central functions of the Condolence Council in Iroquois diplomacy in ritualizing this emphasis on connection to others as follows:

Underlying protocol of treaties and the drama of forest diplomacy was an Indian ceremony for renewing their political forms and restoring society known as the Condolence Council. This developed into a drama in which the actors were Indian sachems and colonial governors. With different casts and slight changes in the script it ran for more than a century, principally at Albany, occasionally at Philadelphia, Lancaster, and Easton, later at Johnson Hall, Fort Stanwix, and Canandaigua. There were French aetors when the play was staged at Montreal. But in its purest form it was celebrated at the great drama festivals held each fall at Onondaga where it is said the ceremony originated with the founding of the League of the Five Nations before the Dutch came to America.

Id. at 18; see also Michael K. Foster, Another Look at the Function of Wampum in Iroquois-White Councils, in Iroquors Diplomacy, supra note 1, at 99.

39. See Daniel K. Richter, Ordeals of the Longhouse: The Five Nations in Early American History [hereinafter Richter, Ordeals], in Beyond the Covenant Chain, supra note 12, at 11, 17-19 (discussing the role of the Condolence Council in preserving the unity of the League of the Iroquois). Several of Richter's conclusions on the role of the League Council have been challenged by Profcssor Tooker. See Tooker, supra note 3, at 313-17. But Richter's analysis of the unifying function of the Condolence Council within the League follows along the lines of most of the other prominent Iroquoian scholars. See, e.g., Fenton, Iroquois Treaty Making, supra note 36, at 10-18.

Contemporary European observers confirmed the role of the Condolence Council in maintaining League unity. For example, the Jesuit missionary Francois Le Mercier, one of the first Europeans to provide an early account of a Council proceeding (witnessed in 1668), described how "all the Deputies from the different Nations are present, to make their complaints and receive the necessary satisfaction in mutual gifts,-by means of which they maintain a good understanding with one another." Richter, Ordeals, supra, at 17 (footnote omitted). "Their Policy in this is very wise," Le Mercier commented, "and has nothing Barbarous in it ... since their preservation depends upon their union, and since it is hardly possible that among peoples where license reigns with all impunity . . . there should not happen some event capable of causing a rupture, and disuniting their minds." Id. at 18 (footnote omitted).

40. The description in the text of the basic pattern of the Council relies primarily on Fenton, Iroquois Treaty Making, supra note 36, at 18-21, and Foster, supra note 38, at 104-08. 
settlement of the "Downminded" Mourners of the dead chief. The Clearminded, announcing they have come to "lift up" and condole the minds of the Mourners, were greeted by a welcoming fire. ${ }^{41}$ Together, at the wood's edge, the two sides performed the Condolence Council ritual of the three bare words of requickening: eyes, ears, and throat. A speaker for the Mourners would "wipe the eyes" of the weary travelers from the Clearminded side with buckskin cloth, so that they could see normally again. He would then "clear their ears" of all that they had heard which might cause them to alter their messages of peace and condolence. Then, offering a beverage, he would "clear[ ] the obstructions from their throats," filled with dust from the forest paths, so that they could speak normally once again. ${ }^{42}$

After this requickening ritual at the wood's edge, the Mourners led the Clearminded "by the arm" 43 to the village council house. There, the Clearminded initiated a sequenced exchange of gifts of wampum strings and belts (the "Porcelain beads" worn by Kiotseaeton) ${ }^{44}$ with the Mourners. Each gift of wampum, highly prized as valuable trading currency throughout the North American colonial frontier, 45 contained the "words" of a

41. Fenton, in describing the program of the Condolence Council, identifies some sixteen discrete events "arranged in a pattern of sequence that has governed its performance since early times." Fenton, Iroquois Treaty Making, supra note 36, at 18-19.

42. Foster, supra note 38 , at 106.

43. Id.

44. See supra text accompanying notes 1-2.

45. On the uses of wampum in the Indian-White trading economy, see generally 1 MorGaN, supra note 3, at 114-15 (discussing the use of wampum in mourning councils); W.M. Beauchamp, Wampum Used in Council and as Currency, 20 Am. ANTIQUARIAN 1 (1898); William N. Fenton, The Hiawatha Wampum Belt of the Iroquois League for Peace: A Symbol for the International Congress of Antitropology, in MEN AND CULTUREs 3 (Anthony F.C. Wallace ed., 1960) (analyzing the Hiawatha Wampum Belt as a mnemonic device for remembering the founding of the original League for Peace); William N. Fenton, The New York State Wampum Collection: The Case for the Integrity of Cultural Treasures, 115 Proc. AM. PHIL. Soc'y 437 (1971) (discussing wampum in the context of claims for the restoration of cultural objects to Indian heirs); Foster, supra note 38 (focusing on the Indian's own understanding of the function of wampum in the councils); J.S. Slotkin \& Karl Schmitt, Studies of Wampum, 51 AM. ANTHRopologist 223 (1949) (discussing the use of wampum before and after white contact); George S. Snyderman, The Functions of Wampum, 98 Proc. AM. PHIL. Soc'y 469 (1954) (discussing wampum from the Indian's own point of view to eradicate misconceptions perpetuated by the failure of whites to understand Indian culture); Elisabeth Tooker, The League of the Iroquois: Its History, Politics, and Ritual, in 15 HANDBOOK, supra note 3, at 418, 422-24 (discussing the uses of wampum in a variety of different contexts).

The wampum beads were cylindrical in shape, made of quahog shells drilled through from opposite ends by Atlantic coast tribes. They were often fashioned into belts and strings and were a principal medium of exchange and diplomacy among the Iroquois and other eastem North American tribes before the artival of Europeans on the continent. The wampum belts exchanged at most Iroquois diplomatic ceremonies and treaty conferences were made of beads of one color, usually "black" (actually dark purple) or white, or a combination of both colors strung to form graphic patterns. Black beads could be used to symbolize death or war, but they could also be used to form a graphic design on a white background symbolizing any number of things. White beads, among other things, could be used to symbolize peace or life. Deganawidah, the Lawgiver and Founder of the Iroquois Confederacy, see infra text accompanying note 54-71, for example, used a belt of white wampum to "signify Great Peace" in forming the League. PARKER, supra note 3 , at 98 . Red painted beads were sometimes added 
message which would be explained in word or song by the speakers from the Clearminded side.

The strings and belts of wampum presented to the Mourners usually spoke of the hardships encountered by the Clearminded in traveling the rivers, rapids, and roads leading to the Mourners' village. A speaker for the Clearminded would offer the wampum gifts to the Mourners, telling the stories "spoken" by the wampum. Typically, these stories spoke of rekindling the fire "to bind us close"; of sorrow for the dead chief; of wiping away any bad blood between the two sides; of eating together; of dispelling the clouds and so restoring the Sun that shines truth on all peoples. ${ }^{46}$ This ritualized exchange was followed by songs meant to condole the loss of the deceased chief. After the Clearminded finished their side of the ceremony, the Mourners reciprocated by presenting their own gifts of wampum, stories, condolences, and songs to the Clearminded. ${ }^{47}$ With these ceremonies completed, a new chief was installed after being selected by the Mourning village's clan women who owned the chief's name and title. ${ }^{48} \mathrm{~A}$ great dance and terminal feast followed. The society was restored; as the Iroquois said, "this will strengthen the house." 49

Europeans usually viewed the sacred rituals upon which Indian tribes relied to negotiate their treaties, such as the Condolence Council, as strange and oftentimes inconvenient ways to conduct vital matters of trade, diplomacy, and survival..$^{50}$ Although the treaty literature gives little evidence of European understanding of Iroquois ways, fragments of the literature, such as Kiotseaeton's speech at Three Rivers, provide us with glimpses of the Iroquois' own expression of their vision of law and peace. From these glimpses we can begin to reconstruct Iroquois legal and political traditions regarding their relations with different peoples, and the ways Iroquois diplomats like Kiotseaeton adapted the language, vocabulary, and metaphors of the Condolence Council into a diplomatic and multicultural discourse.

\section{B. The Founding of the League of the Haudenosaunee}

As Professor William Fenton, the "dean" of Iroquoian ethnography, ${ }^{51}$ has written,

to a war belt, which would then be presented to a potential ally to join forces on a military expedition against some common enemy. See Druke, supra note 11, at 88-90 (discussing the wampum belt as a treaty document).

46. Fenton, Iroquois Treaty Making, supra note 36, at 20.

47. See id. at 19-20.

48. See id. See generally Robert A. Williams, Jr., Gendered Checks and Balances: Understanding the Legacy of White Patriarchy in an American Indian Cultural Context, $24 \mathrm{GA}$. L. Rev. $1019,1036-43$ (1990) (discussing the Iroquois system of using gender-specific roles as cultural checks and balances).

49. Fenton, Iroquois Treaty Making, supra note 36, at 18.

50. See, e.g., Fenton, Iroquois Treaty Making, supra note 36, at 6.

51. See Anthony F.C. Wallace, The Career of William N. Fenton and the Development of Iroquoian Studies, in EXTENDING THE RAFTERs, supra note 3, at 1 (providing a comprehensive 
the institution known as the Condolence Council and ... its supporting props such as wampum strings and mnemonic systems .... perineates the protocol of [Iroquois] treaty making . . . . Not only are key parts of the paradigm of condolence performed in some of the earliest treaties, but the negotiations are embellished by the metaphors in which the later ritual is couched. ${ }^{52}$

The wide diffusion of the Council's symbolic patterns and metaphors throughout recorded Iroquois diplomatic history can be explained, at least in part, by the ceremony's reputed origins in the League's founding and the declaration of the Law of the Great Peace. While there is no written record of the founding of the Haudenosaunee (the Iroquois' own name for their multitribal confederacy), anthropologists and ethnohistorians generally agree that its existence predated European contact. It may have been in existence by the fifteenth century, if not earlier. ${ }^{53}$

Much of what we do know about the League's origms is contained in the Deganawidah Epic, the charter myth of the League's founding. ${ }^{54}$ Most

bibliographical and biographical essay on the career and influence of the man "universally recognized as the dean of Iroquoian studies"); see also EXTENDING THE RAFIERS, supra note 3, at 401-17 (giving a complete bibliography of Fenton's works to 1982).

52. Fenton, Iroquois Treaty Making, supra note 36, at 4 (footnote omitted).

53. See Anthony Wallace, The Death and Rebirth of the Seneca, supra note 3, at 41 (dating the League's emergence at "about 1450"); Fenton, Iroquois Treaty Making, supra note 36, at 16 ("It is certain . . . that the League was founded before European settlement, probably about A.D. 1500, give or take twenty-five years ....."); Richter, Ordeals, supra note 39 , at 16 ("[N]ative traditions and scholarly interpretations point to various eras between A.D. 1400 and A.D. 1600 " as the date of the League's founding.).

54. Fenton, Iroquois Treaty Making, supra note 36, at 14.

The Deganawidah Epic in all of its versions comprises one genre, which in the words of LéviStrauss "can be thought of as belonging together," and in this sense have a single identity over time. But even in societies like the Iroquois who aspire to verbatim recall, each narrator has his own version of the myth: he never tells it twice im precisely the same way, and there is bound to be substitution of content over time. Listeners, nevertheless, recognize the several versions as belonging to the one myth, even though the narrators are unable to agree on details or the precise order of incidents. One need not pursue the search for one true version; it never existed. One can, however, reconstruct its main outlines and plot.

Id. (footnotes omitted).

The descriptions of the League's founding and the Deganawidah epic summarized in this part of the Article are based upon the following sourees: ARthUR C. PARKER, The Constitution of the Five Nations, or the Iroquois Book of the Great Law [hereinafter PARKER, Constitution of the Five Nations], in Parker on the IRoquots, supra note 3; Paul Wallace, The Whtte Roots of Peace, supra note 3; Fenton, Iroquois Treaty Making, supra note 36, at 14-18; William N. Fenton, The Lore of the Longhouse: Myth, Ritual and Red Power, 48 ANTHRopological Q. 131 (1975); Richter, Ordeals, supra note 39, at 16-19; Anthony F.C. Wallace, The Dekanawideh Myth Analyzed as the Record of a Revitalization Movement, 5 ETHNOHISTORY 118 (1958); Paul A.W. Wallace, The Iroquois: A Brief Outline of Their History [hereinafter, Paul Wallace, The Iroquois], in The Livingston Indian RECORDS, 1666-1723, supra note 3, at 15, 15-18.

Founding epics such as the Deganawidah myth provide "for cohesion, for local patriotism, for a feeling of union and kinship in the community." Bronislaw Malinowski, Myth in Primitive Psychology, in Magic, Science and Religion and Other Essays 74, 94 (Robert Redfield ed., 1948). In his important essay, Malinowski sets out to demonstrate that "an intimate connection exists between the word, the mythos, the sacred tales of a tribe, on the one hand, and their ritual acts, their moral deeds, their social organization, and even their practical activities, on the other." Id. at 74. A myth thus serves 
versions of the epic agree that Deganawidah was an Iroquois prophet ${ }^{55}$ born of a virgin ${ }^{56}$ of the Seneca tribe at a time of fierce and debilitating wars, blood feuds, and crises. ${ }^{57}$ The feuds, peril and mourning at the heart of the Deganawidah epic were part of "a cultural pattern known as the 'mourning war' which for the Iroquois, as for many other native Americans, was a principal means of coping with the death of loved ones." 58

Through the inourning war, the Iroquois fulfilled what they regarded as their inoral obligation to avenge inurdered relatives. ${ }^{59}$ Female kin of a deceased person "would appear at public dances and feasts, weeping incon-

as "a warrant, a charter, and often even a practical guide to the activities with which it is connected." $l d$. at 85 . "[O]nce we begin to study the social function of myth, and so to reconstruct its full meaning, we are gradually led to build up the full theory of native social organization." Id. at 94 .

My retelling and interpretation of the Iroquois Deganawidah charter epic, and its integral relation to an understanding of Iroquois social, political and legal traditions during the Encounter era, borrows heavily from Malinowski's ideas of myth. As Clifford Geertz notes, there has been "little conceptual advance" in the field over Malinowski's theory-building efforts. CL.IFFord GeERTz, THB INTERPRETATION OF CULTURES 103 (1973). Geertz's work itself reflects the influence of Malinowski's "sociological" approach on the field of anthropology. Geertz has paraphrased the hroad goal of this approach in one characteristically brilliant and pithy sentence (contained in an essay ruminating on Malinowski's traits as an anthropologist), "The trick is to figure out what the devil they [the "natives"] think they are up to." Clifford Geertz, Local Knowledge 58 (1983). The approach outlined in Geertz's essay, The Way We Think Now: Toward an Ethnography of Modern Thought, in Local KNOwLEDGE, supra, at 147, illuminates somewhat the limited goals I have set out for this Articlc in the field of multicultural legal studies:

The primitive form of the "primitive thought" formulation-that is, that while we, the civilized, sort matters out analytically, relate them logically, and test them systematically, as can be seen by our mathematics, physics, medicine, or law, they, the savage, wander about in a hodgepodge of concrete images, mystical participations, and immediate passions, as can be seen by their myth, ritual, magic, or art-has, of course, been progressively undermined as more about how the other half thinks has become known (and more, too, about just how unvirginal reason is); though it persists in certain sorts of developmental psychology, certain styles of comparative history, and certain circles of the diplomatic service. The error, as in rather different ways both Boas and Malinowski gave much of their careers to demonstrating, lay in attempting to interpret cultural materials as though they were individual expressions rather than social institutions. Whatever the connection between thought as process and thought as product might be, the Rodin model-the solitary thinker mulling facts or spinning fantasies-is inadequate to clarify it. Myths are not dreams, and the rational beauties of mathematical proof are guarantees of no mathematician's sanity.

Id. at 148-49. Geertz's work and its relation to the Iroquois vision of law and peace are discussed further infra Part III.

55. See, e.g., Richter, Ordeals, supra note 39, at 19.

56. See, e.g., PARKER, Constitution of the Five Nations, supra note 54, at 14-15.

57. See, e.g., Richter, Ordeals, supra note 39, at 16.

58. Id.; see also Richter, War and Cultures, supra note 3. In his article, Richter asserts that the psychology of the mourning war was "deeply rooted in lroquois demography and social structurc" and emphasizes its functions in "the maintenance of stable population levels." Id. at 529 n.4, 530; $c f$. Marian W. Smith, American Indian Warfare, 13 TRANSACtions N.Y. ACAD. SCI. 348, 352-55 (1951) (stressing the psychological and emotional functions of the mourning war).

59. Generally speaking, whatever economic or political considerations might be involved in the tensions that led to war, the actual formation of war parties was either inspired or rationalized by the obligation to avenge dead relatives. ... [U]ntil there had been retaliatory killings and tortures, it was as if the blood of the murdered one had not been wiped away and his corpse not covered. War-caused bereavement was a state of unavenged insult and shame ....

Anthony Wallace, The Death and Rebirth of the Seneca, supra note 3, at 101. 
solably; if this display did not succeed in arousing the warriors, the women might offer payments or accuse the lagging warriors of cowardice."60 Men might have disturbing dreams and visions of their murdered kin and request the warriors in the tribe to raid an enemy village for captives. ${ }^{61}$ The captives would either be executed according to the set rituals of the mourning process, or adopted into the grieving family as "an almost literal replacement for the departed." feuds of the Deganawidah epic. ${ }^{63}$

According to the epic, Deganawidah, with Hiawatha as his agent, formed the Iroquois Confederacy in this time of chaos, and endowed it with the ceremonies of the Condolence Council. "[I]n compassion for man, the victim of recurrent wars," the Great Spirit incarnated in Deganawidah the message of "Peace and Power."64 This divinely-inspired vision taught that men should stop hunting, killing, and scalping one another. ${ }^{65}$ Hiawatha, enraged by the cycle of warfare and the death of his daughters, wandered into the forest where he met Deganawidah and learned the rituals of condolence accompanying Deganawidah's message of peace. ${ }^{66}$

Offering strings of wampum, Deganawidah spoke several words of condolence: the first dried Hiawatha's weeping eyes, the second opened his ears, the third unstopped his throat, and so on until his sorrow was relieved and his reason restored. These condolence ceremonies were at the core of a new gospel, the Good News of Peace and Power, that would make mourning wars unnecessary. "When men accept it," Deganawidah said of his message, "they will stop killing, and bloodshed will cease from the land." $" 67$

Deganawidah carried the "Great Law" to the local chiefs of the Iroquois settlements, and urged them to "abandon their feuds, reform their minds, and unite."68 A "Tree of Peace" was to be planted among the Iroquois, with its "White Roots of Peace" extending the Good News of Peace and Power to all peoples. ${ }^{69}$ The Condolence ceremonies which
60. $I d$.
61. See id.
62. Richter, Ordeals, supra note 39 , at 16.
63. Id.
64. Paul Wallace, The Iroquois, supra note 54, at 17.
65. Fenton, Iroquois Treaty Making, supra note 36, at 14.
66. Richter, Ordeals, supra note 39, at 16-17.
67. Id. at 17 .
68. Fenton, Iroquois Treaty Making, supra note 36, at 15.
69. See Paul Wallace, The Iroquois, supra note 54, at 17; see also PARKER, Constitution of the Five Nations, supra note 54, at 8-9.
I am Dekanawideh and with the Five Nations' confederate lords I plant the Tree of the Great Peace. I plant it in your territory Adodarhoh and the Onondaga Nation, in the territory of you who are fire keepers.
I name the tree the Tree of the Great Long Leaves. Under the shade of this Tree of the Great Peace we spread the soft, white, feathery down of the globe thistle as seats for you, Adodarhoh and your cousin lords.
... There shall you sit and watch the council fire of the Confederacy of the Five Nations. 
embodied this Good News thus became, in a strong sense, the reason for the existence of the League of the Iroquois.

In orgaming this Great League of Peace around the Condolence Council, Deganawidah and Hiawatha divided the Grand Council of the Fifty Chiefs of the five Iroquois tribes into two major sides, or "moieties": the Elder Brothers-the Mohawks, Onondagas, and Senecas; and the Younger Brothers-the Oneidas and the Cayugas. ${ }^{70}$ Deganawidah charged the two sides with exchanging the ceremonial gifts and words of condolence upon the death of one of their chiefs. At its very founding, then, a vital function of the League's Grand Council was, in Professor Richter's words, "to preserve the Great Peace through ceremonial Words of Condolence and exchanges of ritual gifts."71 Throughout the Five Nations

Roots have spread out from the Tree of the Great Peace ... and the name of these roots is the Great White Roots of Peace. If any man of any nation outside of the Five Nations shall show a desire to obey the laws of the Great Peace... they may trace the roots to their source ... and they shall be welcomed to take shelter beneath the Tree of the Long Leaves.

The smoke of the confederate council fire shall ever ascend and shall pierce the sky so that all nations may discover the central council fire of the Great Peace.

I, Dekanawideh, and the confederate lords now uproot the tallest pine tree and into the cavity thereby made we cast all weapons of war. Into the depths of the earth, down into the deep underearth currents of water flowing into unknown regions, we cast all weapons of strife. We bury them from sight forever and plant again the tree. Thus shall all Great Peace be established and hostilities shall no longer be known between the Five Nations but only peace Id. to a united people.

70. Richter, Ordeals, supra note 39 , at 17. Besides arranging the Council in two moicties for purposes of condoling and mourning, Deganawidah also set out "a tripartite seating" for purposes of business at the Great Council Fire. The Mohawks and Senecas sit to the East, the Oneidas and Cayugas sit to the West, and the "firekeepers," the Onondagas, sit to the north, acting as arbiters of the two opinions. Fenton, Iroquois Treaty Making, supra note 36, at 15. See generally PARKER, Constitution of the Five Nations, supra note 54, at $30-33$ (describing the structure of the Great Council in terms of the League's principles).

The Deganawidah epic was not recorded in writing until late in the nineteenth century. See Fenton, Iroquois Treaty Making, supra note 36, at 15 . In describing the council seating arrangements, Fcnton cites the version of the epic edited and recorded by Arthur C. Parker, an Iroquois anthropologist, and contained in Parker's 1916 monograph, PARKer, Constitution of the Five Nations, supra note 54. As Fenton describes, the efforts by "native annalists to codify" the charter for the League of Five Nations pointed to "a process of projeetion and feedback of content, structure and ritual process that is yct evolving." Fenton, Iroquois Treaty Making, supra note 36, at 15 (footnote omitted). Not surprisingly, then, several of Parker's renditions of the "by-laws" governing the League's internal structure and rituals contain "a distinct nineteenth century tone," though others "hark back to aboriginal times." Id.

In relating the epic of Deganawidah's founding of the League, 1 have sought to convey the basic outlines of the story as generally agreed upon by most of the major sources consuitcd in my rcsearch. These include primarily PARKER, Constitulion of the Five Nations, supra note 54; THE IROQuOIs Book OF RITES, supra note 3, at 18-38; J.N.B. Hewitt, Legend of the Founding of the Iroquois League, 5 AM. ANTHROPOLOGIST 131 (1892). For critical commentary on the various versions of the Iroquois "Constitution," see William N. Fenton, Introduction to Arthur C. PARKer, PARker on the 1roquols, supra note 3, at 38-46; Fenton, Iroquois Treaty Making, supra note 36.

71. Richter, Ordeals, supra note 39 , at 18.

In rites that filled the better part of a day, members of the "clear-minded" moiety spoke the Words of Condolence to the mourning side and requickened the deceased sachem in the person of a kinsnian chosen by the older women of the dead leader's lineage. Thus were kept alive the fifty sachems and, metaphorically, the League itself. Condolence rituals, ceremonial gifts, and requickening rites symbolicaliy addressed the same demographic, social, and psychological needs served by the mouming war. In these ceremonies could be found the 
of the League, the Condolence Council supplanted the mourning war as the institution for mourning the dead.

For the Iroquois, as for many other eastern North American Indians, peace was a matter of "good thoughts" between different peoples, "a feeling as much as a reality." 72 "Headmen could not force anyone to forgo mourning-war raids; they could only advise, persuade, cajole, and invoke the obligations of kinship." 73 The League and its rituals operated to maintain the channels of communication that sustained and renewed the connections of peace and goodwill that bound the confederated tribes and made them of "one mind."74

The Deganawidah Epic, "with its wisdom and its poetry, seized the imagination of the Iroquois people, who took to heart the message it conveyed and derived from it a sense of national mission: to make the Tree of Peace prevail." 75 The "good news" of Deganawidah's message envisioned a multicultural community of all peoples on earth, linked together in solidarity under the sheltering branches of the Tree of Great Peace.

Roots have spread out from the Tree of the Great Peace .... If any man of any nation outside of the Five Nations shall show a desire to obey the laws of the Great Peace ... they may trace the roots to their source... and they shall be welcomed to take shelter beneath the Tree of the Long Leaves.

The snioke of the confederate council fire shall ever ascend and shall pierce the sky so that all nations may discover the central council fire of the Great Peace. ${ }^{76}$

The Deganawidah epic was an "ever-present, live actuality," prescribing the political and legal rituals and traditions by which a confederacy of once alienated and warring tribes maintained, renewed, and extended the Good News of Peace to all peoples. ${ }^{77}$ It was, as Professor Malinowski has

spiritual power that others gained from war. The Good News of Peace and Power, then, sought to replace the mourning war with what might be termed the mourning peace.

Id. at 17.

72. John P. Reid, A Better Kind of Hatchet: Law, Trade, and Diplomacy in the Cherokee Nation During the Earty Years of European Contact 16 (1976). Reid is referting to the Cherokees' concept of peace, but the notion applies equally to the Iroquois. See Richter, Ordeals, supra note 39 , at 18.

73. Richter, Ordeals, supra note 39 , at 18.

74. See Fenton, Iroquois Treaty Making, supra note 36, at 13 (discussing the importance of attaining "one mind" in the Iroquois system of government).

75. Paul Wallace, The Iroquois, supra note 54, at 17. The Deganawidah epic provided what Professor Wallace calls a "patriotic incentive," binding the Iroquois together as a confederated people. He argues that the League's frequent wars throughout the Encounter era assumed "something of the complexion of religious crusades." Id.

76. PARKER, Constitution of the Five Nations, supra note 54, at 9.

77. See MaLnNowsKa, supra note 54, at 102-03:

And this brings us once more to our original contention that the really important thing about the myth is its character of a retrospective, ever-present, live actuality.... It is clear that myth functions especially where there is a sociological strain, such as in matters of great difference in rank and power, matters of precedence and subordination, and unquestionably where 
explained about such founding epics generally, "neither a fictitious story, nor an account of a dead past; it is a statement of a bigger reality still partially alive. It is alive in that its precedent, its law, its moral, still rule the social life" of the culture which adopts it as meaningful. ${ }^{78}$

\section{Iroquois Social Life and Culture}

Guided by the Deganawidah epic as their legal and moral precedent, the Iroquois were, in every sense of the word, a people of connections; connected to each other and to those differing peoples they sought to bring within their alliance under the great Tree of Peace. ${ }^{79}$ The Iroquois vision of law and peace, ritualized in the Condolence Council and elaborated by Iroquois diplomats as part of a practice of negotiating multicultural constitutional covenants, is rooted in the complex web of reciprocating relationships, mutual interdependencies, and dialogic interaction prescribed at the founding of their League of confederated tribes. ${ }^{80}$

\section{Family, Clan and Kinship Connections}

The social organization of the Iroquois tribes was built on a conplex web of kinship relationships, both real and symbolic. Each nation was comprised of separate villages and longhouse families. Villages, at least during the early Encounter era, were typically composed of a cluster of 30 to 150 longhouses surrounded by a palisade, outlying agricultural fields, and a forest, usually a range of territory encompassing the village's hunting and gathering grounds. Ideally, a village would be situated on a height of land accessible to drinking water and not too far removed from a water-

profound historical changes have taken place. So much can be asserted as a fact, though it must always remain doubtful how far we can carry out historical reconstruction from the myth.

78. Id.

79. See Mary A. Druke, Linking Arms: The Structure of Iroquois Intertribe Diplomacy, in Beyond the Covenant Chain, supra note 12, at 29. "Alliance was a goal desired by Iroquois pcople in relationships with everyone in their universe. In addition to humans, there were numerous other beings who had access to power and could use it in either harmful or helpful ways." Id.

80. To the Iroquois, alliances were dynamic, ongoing relationships, and if they were not kept alive-were not continually improved-friends might tum to enemies over minor differences, just as animal beings might send illness if not regularly solicited for good health. Connections, therefore, were constantly being reevaluated, refined, renewed, and kept alive in ritual form. Reciprocity-through gift-giving and exchange of wampum at councils as well as such things as aid supplied in time of need-expressed mutual commitment. In 1751, for example, the Cayuga Ottrawana reported that Mississaugas confirmed their alliance with the Iroquois and promised "to keep it firm and strong." Such statements resound throughout the historic record. The need for continued reassurance made personal interactions extremcly important to the Iroquois in intertribal diplomacy. When Virginians insisted in 1719 that the Five Nations uphold peace with Indians in alliance with them, an Iroquois sachem expressly stated that " 2 years ago the Governor of Virginia made complaints of some of their Pcople doing Mischief in his Country and that they had desired he would come himself or Depute some Body to come to Albany with some of the Indians in Alliance that they might adjust matters Face to Face." This was the manner of doing things. Despite rhetoric, hostilities might arise, and alliances were not infrequently broken, but documentary evidence of Iroquois diplomacy is full of efforts to establish, renew, or reestablish peaceful relationships.

Id. at 33 (footnotes omitted). 
way. ${ }^{81}$ Each village had its own Chief, whose name was the same as his village. ${ }^{82}$ The Chief's home served as a council house, where ambassadors to the village would call and where the village would assemble to hear an ambassador's message. ${ }^{83}$

The Iroquois family was usually organized around a multifamily maternal lineage: an elder woman and her daughters, her unmarried sons, and the husbands and children of her married daughters. ${ }^{84}$ Families lived in close and continual connection in the traditional Iroquois longhouse, a structure fifty to seventy-five feet long and housing up to sixty people. ${ }^{85}$ Families formed the segments of clans, and the eight clans distributed throughout the five tribes (Wolf, Bear, Beaver, Turtle, Hawk, Snipe, Deer, and Heron) comprised the building blocks of Iroquois culture and society. ${ }^{86}$

The clan system defined the kinship connections between individual members of the tribes. All members of a clan were supposed to be descended from a common ancestor, and clan members of the same generation treated each other as siblings. ${ }^{87}$ Marriage between members of the same clan was not allowed. A child's clan affihation was determined at birth by his or her mother's clan, unless "borrowed" or "adopted" by another clan in a formal ceremony. ${ }^{88}$ For example, a child whose mother was a Seneca Bear Clan member and whose father was a Mohawk Wolf Clan member would have been a Seneca Bear Clan member. ${ }^{89}$

81. See Fenton, Iroquois Treaty Making, supra note 36 , at 7.

82. Id. at 9. This tradition of linking the name of a headman to his settlement extended even to Iroquois relations with European colonial officials. For example, the Iroquois called all of New France's Governors "Onontio," which meant "Great Mountain." This name can be traced to the first governor engaged in open warfare with the Iroquois, Govemor General Charles Huault de Montmagny (1636-48). See Jennings, The Ambiguous Iropuois Empire, supra note 3, at 90, 96.

83. Fenton, Iroquois Treaty Making, supra note 36, at 9 . Iroquois towns frequently had multiple chiefships, representing smaller residential segments. For example, each Mohawk town had three chiefships, each belonging to a segment, lineage, or household. Id.

84. See id. at 10. Fenton has described the matrilineal clan organization of the Iroquois, stemming from the "fireside family," in the following terms:

Stemming from the fireside family and including any living siblings of the wife's mother, both male and female, the wife's brothers and sisters, the wife's children, and her daughter's children, and the descendants of any of the preceding women in the female line, is the household of fact and legal fiction, or the continuing matemal family. Ascending the matrilineal scale, the senior living woman is the matriarch and she presides over the household and makes ultimate decisions on social and political matters. This lineage of persons tracing descent froin a common mother forms an exogamic incest group, members of which must take their spouses from other similar matrilineages. In time such a lineage might occupy several longhouses in several villages, giving rise to segments of a clan.

Id. at 10 .

85. Anthony Wallace, The Death and Rebirth of the Seneca, supra note 3, at 22.

86. Id. at 14; Williams, supra note 48, at 1038-39.

87. See Fenton, Iroquois Treaty Making, supra note 36, at 10; see also ANTHONY WALLACE, ThE Death and Rebirth of the SEneca, supra note 3, at 14.

88. Anthony Wallace, The Death and Rebirth of the Seneca, supra note 3, at 14-15.

89. See id. 
The clan system served to organize and sustain reciprocal relations of kinship, interdependence, and communication across Iroquois culture. ${ }^{90}$ Each village was divided into two moieties, or sides, comprised of two or more separate clans, with reciprocating relationships and ceremonial functions defined by custom and tradition. Iroquois rituals all carried the theme of reciprocal benefices between two related sides, often with one moiety supporting, or "giving" the ceremony to, the other. ${ }^{11}$ Moieties would reciprocally condole and bury each other's dead. They performed games like lacrosse together, to drain internal tensions. The moiety concept thus provided "a ready tool for the organization of reciprocal behavior on almost any ritual occasion." 92

The close connections of kinship sustained by the clan system were reinforced by an ethical ideal of autonomous responsibility taught from early childhood. Children "were carefully trained to think for themselves but to act for others." ${ }^{23}$ The reciprocal kinship connections between individual clan members continually reinforced the meaning of this fundamental precept of Iroquois culture. Clan members were expected to maintain good relations through purposive action, such as exchanging gifts or sharing food in times of shortage. Through frequent ceremonies and rituals, clan members remained in continual contact and communication. ${ }^{94}$

Clan members had a right to call on the generosity of each other. For example, a traveler in a strange village with no known relations would look

90. The clan structure also served to govern the daily lives of the Iroquois. Women played a powerful role within this structure, owning and controlling the longhouses and agricultural fields, and directing the distribution of food within the longhouse and to other longhouses of their clan. See supra note 84.

On the role of women in Iroquois culture, see generally ARTHUR C. PARKER, Iroquois Uses of Maize and Other Food Plants, in PARKER ON THE IROQUOIS, supra note 3, at 5, 21-24 (discussing the division of labor by gender); Judith $\mathrm{K}$. Brown, Economic Organization and the Position of Women Among the Iroquois, 17 Ethnohistory 151 (1970); Martha C. Randle, Iroquois Women, Then and Now, 149 Bureau AM. Ethinology Bull. 167 (1951); Elisabeth Tooker, Women in Iroquois Society, in EXTENDING THE RAFTERS, supra note 3, at 109; Williams, supra note 48.

91. See Anthony Wallace, The Death and Rebirth of the Seneca, supra note 3, at 15; Fenton, Iroquois Treaty Making, supra note 36, at 10-11.

92. Anthony Wallace, The Death and Rebirth of the Seneca, supra note 3, at 15.

93. Id. at 34. Iroquois cultivation of this ideal of autonomous responsibility explains the lroquois' strong belief that no one could tell another person in the tribe what to do. For Europeans, Iroquois methods of socialization were oftentimes difficult to accept.

The Europeans who observed this pattern of child experience were by no means unfavorably impressed although they were sometimes amazed. They commented, however, almost to a man, from early Jesuit to latter-day Quaker, on a consequence that stood out dramatically as they compared this "savage" maturation with "civilized." "There is nothing," wrote the Jesuit chronicler of the Iroquois mission in 1657, "for which these peoples have a greater horror than restraint. The very children cannot endure it, and live as they please in the houses of their parents, without fear of reprimand or chastisement." One hundred and fifty years later, the Quaker Halliday Jackson observed that "being indulged in most of their wishes, as they grow up, liberty, in its fullest extent, becomes their ruling passion." The Iroquois themselves recognized the intensity of their children's resentment at parental interference.

Id. at 38 (footnotes omitted).

94. See Anthony Wallace, The Death and Rebirth of the Seneca, supra note 3, at 15; Druke, supra note 79 , at $29,33$. 
to members of his clan for food or lodging. ${ }^{95}$ "Who are your people?," meaning what clan are you from, was likely the first question asked a visiting Iroquois in a strange village:

The totem animal of the clan to which the lineage belonged-Deer, Bear, Wolf, Smipe, or whatever it might be-was carved above the door and painted red. In this way directions were easier to give, and the stranger knew where to seek hospitality or aid. ${ }^{96}$

\section{Projection of the Iroquois Kinship System onto the Structure of the League}

The intricate system of clans and lineages provided the Iroquois with a ready-made structure for maintaining the social, political and military cohesion of their multitribal confederacy. The strong sense of connection and solidarity which each Iroquois individual had to others in his or her extended network of clan, village, and intratribal and intertribal relationships was reinforced by a set of kinship terms derived from the fireside family. ${ }^{97}$ For exanuple, the two moiety halves of the League, the Elder Brothers (Mohawk, Onondaga, and Seneca) and Younger Brothers (Oneidas and Cayugas), were defined by the kinship terms "uncles" and "nephews", respectively. ${ }^{98}$ These kinship terms, in essence, defined the individual's limes of appeal and responsibility to others.

[A]s one moves from the lineage to the clan, to the moiety, to the tribe or nation, and thence to the League, the projected use of kinship terms becomes more fictional and the expected behavior more symbolic. The principle that operates throughout this extension is duality or reciprocity. Even one's fictional or symbolic relatives were expected to respond in kind with set speeches of condolence, wanupum string or belt or its like, present for present, word for word . . .99

In Iroquois culture, therefore, the individual was situated in a web of reciprocating relations involving gift-giving, sharing and commumication with others. These relationships were established at birth, maintained throughout life, and culminated at death in the rituals of condolence and requickening. Through the Condolence Council ceremonies, the Iroquois spread the good news of peace between clan members, to the different clans comprising the moieties and the tribe, and to the five tribes allying under the League. Taught from childhood to think independently and act for others, the Iroquois survived in the hostile world of the early Encounter era

95. Anthony Wallace, The Death and Rebirth of the Seneca, supra note 3, at 15.

96. Id. at 23.

97. "The simplest unit of Iroquois society is the 'fireside' or nuclear family [comprised] of husband and wife and their children." Fenton, Iroquois Treaty Making, supra note 36, at 10.

98. See id. at 11 .

99. Id. at 12. 
by maintaining the ritual connections of sharing and reciprocity that defined their indigenous way of life. ${ }^{100}$

\section{The League and Its System of Governance}

Those who developed the structure of the League of the Iroquois ${ }^{101}$ understood that the web of connections regarded as vital to the Iroquois' survival and flourishing could only be sustained by keeping open the channels of communication between the individuals, clans, villages, and tribes comprising the League. In a culture which expected individuals to think independently and act for others, the highest value was placed on open and undistorted dialogue. Thus, in the Iroquois system of governnent, all persons were entitled to have their opinions heard on League policy and action. Above all, the Iroquois political systenı sought to assure that the Iroquois listened seriously to each other. ${ }^{102}$

Unique methods of assuring full consultation of all individuals affected by group decisions operated at the niost basic levels of Iroquois political structure. For example, although men held all fifty chieftainships on the League Council, the office titles were the undisputed property of the women heading the natrilineal clans. When a clan chief (or sachem) died, his name and title reverted back to the head clan mother, who, in consultation with the other women in the clan, selected a new chief fronl among the clan males. ${ }^{103}$ The women of the clan also had the power to "dehorn," or remove from power, a chief deemed unfit to serve. ${ }^{104}$ Through this systen of gendered checks and balances, the Iroquois sought to assure that wonien, who controlled such vital functions as crop production and the provisioning

100. See Druke, supra note 79 , at $32-33$.

101. It was Lewis $\mathrm{H}$. Morgan, considered the founder of modern ethnography, who first made available the "structure of the League" in published form, in his seminal study. See MoroAN, supra note 3. Professor Tooker relates Morgan's interest in the League to his membership in a secret socicty called the Gordian Knot, which looked to the League as a model for a fraternal socicty. Tooker, supra note 3, at 311. The problem for Morgan in researching the "structure of the League" (Morgan's tcrm) was the absence of any information in the literature. Morgan's society, with Morgan performing much of the fieldwork, turned to the Iroquois themselves. The Iroquois, through their own storics of the form of governance they had adopted at the time of the confederation, provided the empirical data for Morgan's study, which initiated modern ethnographic research. Id.

102. On the Iroquois' penchant for frequent cross-consultations between groups and individuals, see Morgan, supra note 3, at 99-103; Anthony Wallace, The Death and Rebirth of the Seneca, supra note 3, at 39-41; Druke, supra note 79; Michacl K. Foster, On Who Spoke First at Iroquois-White Councils: An Exercise in the Method of Upstreaming, in ExTENDING THE RAFTERs, supra note 3 at 183, 183-85; Haan, supra note 13. On the Iroquois system's emphasis on listening scriously to each other, and its meanings for the multicultural world we encounter today, see infra Part III.

103. Tooker, supra note 3 , at 12. Chieftainships thus did not pass from father to son, or even necessarily remain within a family. The clan mother might choose a favored son, or a nephew born of a sister, but she and the other clan women would also consider a potential chief's standing in the community and those leadership qualities valued by the Iroquois-generosity, courage, patience, temperance, and a good sense of Indian humor. See Williams, supra note 48, at 1039-40 (discussing the female role in seleeting chiefs as a check on male power).

104. Williams, supra note 48 , at 1040. 
of the longhouse family and clan members, were consulted and listened to on clan, village, tribal, and League affairs. ${ }^{105}$

Checks and balances to assure consultation, dialogue, and solidarity also permeated the League Council of Fifty Chiefs, which was responsible for maintaining both the external affairs of trade, alliances and treaties, ${ }^{106}$ and the internal social, military, and political solidarity between the five nations within the League. Representation on the Council was not evenly divided between the tribes and clans, nor was it apportioned on the basis of population. ${ }^{107}$ The unequal distribution of voting seats, however, did not translate into unequal voting power. Checks and balances to assure equal

105. Id. at 1039-43; see also Randle, supra note 90, at 169-73. The role of men in Iroquois culture was directed more to activities outside the longhouse and village. Men hunted and fished, and protected the tribe in war. The men also built the longhouses and cleared the forests for new agricultural fields. They owned very little in terms of property. Their personal effects such as knives and guns measured the extent of their recognized property interests in the tribe. Even the food which men killed was regarded as belonging to the wife's Clan. See generally Randle, supra note 90 (discussing the role of men in relation to the women in Iroquois society); Williams, supra note 48, at 1036-44 (discussing gender roles in Iroquois society).

106. See Tooker, supra note 3 , at 312-16.

The councils of the League were of three distinct kinds: civil, mourning and religious. Civil councils concerned League governance issues and were designated by the name Ho-de-os-seh, which translates as "advising together." MorgaN, supra note 3, at 103-04. The civil councils of the League "convened to transact business with foreign nations, and to regulate the internal administration of the Confederacy." Id. at 103 . Each nation of the League had the authority to convene such a council. Id. at 104.

Morgan describes the usual manner in which the League council "advised together" and listened to each other during a Ho-de-os-seh convened to hear the message of an envoy from a foreign nation as follows:

If the envoy of a foreign people desired to submit a proposition to the sachems of the League, and applied to the Senecas for that purpose, the sachems of that nation would first determine whether the question was of sufficient importance to authorize a council. If they arrived at an affirmative conclusion, they immediately sent out runners to the Cayugas, the nation nearest in position, with a belt of wampum. This belt announced that, on a certain day thereafter, at such a place, and for such and such purposes, mentioning them, a council of the League would assemble. The Cayugas then notified the Onondagas, they the Oneidas, and these the Mohawks. Each nation, within its own confines, spread the information far and wide; and thus, in a space of time astonishingly brief, intelligence of the council was heralded from one extremity of their country to the other. It produced a stir anong the people in proportion to the magnitude and importance of the business to be transacted.

Id. at 104 (footnote omitted).

The Council did not govern the internal affairs of the tribes, which were the responsibility of the tribal councils. Tooker, supra note 3, at 316. Nor was the Council primarily concerned with waging war. Under the law of the Great Tree of Peace, as the League "was at war with all nations not in their actual alliance, it was lawful for any warrior to organize a party, and seek adventure wherever he pleased to direct his steps." Id. (footnote ounitted). However, when the League nations did find themselves allied in prosecuting a common war

and their forces were united into one body, an expedient was resorted to for securing unanimity in their plans, in the establishment of two supreme military chieftaincies. The two chieftains who held these offices were designed rather to take the general supervision of the affairs of war, than the actual command in the field, although they were not debarred from assuming it, if they were disposed to do so. These war-chiefships [both held by the Seneca] were made hereditary, like the sachemships, and vacancies were filled in the same manner.

Id. (footnote omitted).

107. Tooker, supra note 3, at 312. The Senecas, the largest of the Five Nations, had only eight of the fifty Council chieftainships. The Mohawks and Oneidas each had nine, the Cayugas ten, and the 
voting power to each of the five nations were maintained through adherence to the principle of unanimity. Under that principle, the Council could set League policy only when all fifty chiefs were in clear consensus, and when all other Iroquois, men and women, were in basic agreement with this consensus. ${ }^{108}$ If unanimity could not be achieved, "the whole matter was laid aside."109

Unanimity was an absolute necessity in a culture which taught individuals to think independently. ${ }^{10}$ Each League village and community had "its [own] local ways which it zealously maintained and defended."111 Serious disagreements over policy might lead a dissident individual or group to declare themselves out of the confederacy, threatening the tribal community's cohesion and viability. ${ }^{112}$ The process of reaching a consensus by extensively discussing issues anıong subgroups of the Council and then among the entire Council ${ }^{113}$ assured that the chiefs, who as clan and

Onondagas fourteen. Nor were the eight clans equally represented on the Council. For example, some of the Onondaga, Cayugas and Seneca clans did not have any council chiefs at all. ld.

108. See Morgan, supra note 3, at 106; Tooker, supra note 3, at 315-16.

109. MORGAN, supra note 3, at 107.

110. See supra note 93 and accompanying text.

111. Fenton, Iroquois Treaty Making, supra note 36, at 9.

112. Tooker, supra note 3 , at 315 .

Unanimity was not merely an ideal; it was a necessity. Communities were small and lacked any duly instituted police force to deal with potentially divisive actions. Lacking that "coercive force" to prevent dissenters from simply moving out of the community and hence greatly weakening its ability to defend itself, considerable effort was devoted to finding consensus.

Id.

113. See Morgan, supra note 3, at 106-07; Tooker, supra note 3, at 312.

In these deliberations, the Mohawks and Senecas sat on one side of the council fire; the Oneidas and Cayugas on the other side and facing them; and the Onondagas, the "firekeepers" of the League, on a third side. As they were the firekeepers, the Onondagas were charged with the responsibility of presenting the matter to be discussed and, after the sachems of each tribe had agreed aniong themselves and with the saehems of other tribes, of announcing the decision, thus confirming and proclaiming it.

Id.

Council process divided the sachems from the same tribe into classes of two or three chiefs. A sachem could express an opinion in Council only in agreement with the rest of his class, and only after having becn appointed as a speaker for his class. For example, the eight Seneca sachems were divided into four classes. Each class was brought to unanimity within itself as the members agreed on their opinion and appointed a speaker. The appointed speakers of each of the four Seneca classes then consulted until they reached a consensus. The four then appointed a speaker to express the resulting opinion, the official position of the Seneca Nation, in Council. See MoroAn, supra note 3, at 106.

The several nations having, by this ingenious method, become of "one mind" separately, it only remained to compare their several opinions, to arrive at the final sentiment of all the sachems of the League. This was effected by a conference between the individual representatives of the several nations; and when they had arrived at unanimity, the answer of the League was determined.

Id. at 106-07.

While the idea of requiring unanimity of the Five Nations of the Confederacy might at first appear unworkable, it should be remembered that each tribe regarded itself as both autonomous and interdependent in its relations with the other League members. The manner of reaching consensus assured that "[t]he sovereignty of the nations . . . was not only preserved, but made subservient to the effort itself to secure unanimity." Id. at 107. The League's effectiveness was related to the sachems' 
village leaders knew the opinions of their communities, ${ }^{114}$ spoke with "one voice, one mind, and one heart."115

The requirement of unanimity determined the means of communicating concerns from the smallest fire of the clan longhouse to the great League Council fire at Onondaga, and vice versa. As described by the Reverend Asher Wright, a nineteenth century missionary to the Senecas:

If any individual desired to bring any proposition before the general council, he must first gain the assent of his family, then his clan, next of the four related clans in his end of the council house, then of his nation, and thus in due course ... the business would be brought up before the representatives of the confederacy. ${ }^{116}$

The Council did not impose its decisions on the League, but rather communicated them to the people for their approval. Because Iroquois culture dictated that no person could tell another what to do, the sacheins in fact had little power. ${ }^{17}$ "[W] $[\mathrm{W}$ en the chiefs had attained 'one mind,' an appeal was made to the people, hoping they would agree."118

Decisions of the League Council, then, reflected a long chain of communication and consultation linking the clans, villages, and tribes of the Iroquois together in "one mind." By necessity, councils were long and frequent. $^{119}$ All positions were listened to seriously. Ultimately, however, adherence to the unanimity mle seldom hindered the Council's ability to act. ${ }^{120}$ According to the vision governing the Iroquois multitribal confederacy, diverse peoples were brought together in "one mind" througlı a system designed to assure that all parties listened seriously to each other.

recognition of the mutual interests of their communities and tribes with respect to a particular issue or crisis.

114. Although not all village chiefs were sachem chiefs with seats on the Council, they exercised a great deal of power primarily because they rose to positions of village leadership by virtue of their influence within their local pohties. The sachems naturally listened to these "ordinary" chiefs, and these "ordinary" chiefs in tum paid close attention to Council business. Thus, the powers of the sachem chiefs in Council could be checked by the ordinary chiefs' power within their communities. Tooker, supra note 3, at 318-19.

To maintain that check, "ordinary" chiefs were normally not allowed to ascend to the position of sachem chief. See id. at 319. As Morgan noted of the famous Seneca chief and orator Red Jacket:

With all the influence which he exercised over the people by the power of his eloquence, and with all the art and intrigue which his capacity could suggest, he was never able to elevate himself higher than to the title of Chief. ... The Senecas themselves aver, that it would have been unwise to raise up a man of his intellectual power and extended influence to the office of sachem; as it would have concentrated in his hands too much authority.

Morgan, supra note 3, at 98.

115. Fenton, Iroquois Treaty Making, supra note 36 , at 13.

116. Id. at 12-13.

117. Id. at 12 .

118. Id. at 33 n.22.

119. Tooker, supra note 3 , at 315 .

120. Morgan, supra note 3 , at 107. 


\section{E. The Condolence Council and the Iroquois Vision of Law and Peace}

As shown above, Iroquois tribal values of establishing and maintaining mutual relations of connection and communication permeated all aspects of League governance. The evocative imagery, metaphors, and rituals of the Deganawidah epic reinforced and enhanced these critical League functions of unity and dialogue within the Iroquois' multitribal confederacy. According to the epic, Deganawidah himself had linked the five tribes of the Iroquois together in the circle of peace and solidarity as one people. "We therefore bind ourselves together," Deganawidah had said, "by taking hold of each other's hands firmly and forming a circle so strong that if a tree shall fall prostrate upon it, it could neither shake nor break it, and thus our people and our grandchildren shall remain in the circle in security, peace, and happiness." 121

\section{The Institutional Role of the League Council}

According to the laws laid down by Deganawidah, responsibility for maintaining the security, peace, and happiness of the Iroquois people fell to the League Council. As the Great Lawgiver had declared to the sachem chiefs at the founding of the Confederacy: "you are to work and carry out the principles of all that I have just laid before you for the welfare of your people and others." 122 In order to maintain the Great Peace, the sachem chiefs had to possess extraordinary qualities of character. "The thickness of their skin shall be seven spans-which is to say that they shall be proof against anger, offensive actions and criticism," Deganawidah had proclaimed. "Neither anger nor fury shall find lodgement in their minds and all their words and actions shall be marked by calm deliberation."123 A predisposition toward peace was therefore the niost important constitutional requirement for membership in a body devoted to maintaining the social, military, and political solidarity of the Iroquois as a confederated people.

The role of the Council in nraintaining the Great Peace was tied closely to the Iroquois conception of political time as reflected in the Deganawidah epic. ${ }^{124}$ For Iroquois political thinkers, the Deganawidah story taught that the organization of their confederated League had brought

121. PARKER, Constitution of the Five Nations, supra note 54, at 102 .

122. See id. at 103 .

123. Richter, Ordeals, supra note 39, at 18 (footnote omitted) (quoting PARKER, Constitution of the Five Nations, supra note 54, at 37).

124. On the interrelationship of societal conceptions of time, traditions, law and politics, sec generally Geertz, Person, Time, and Conduct in Bali, in The Interpretation of Cultures, supra note 54, at 360 (analyzing the cultural apparatus of the Balinese to give credence to the proposition that human thinking is essentially a social activity); Pocock, Time, Institutions, and Action; An Essay on Traditions and Their Understanding [hereinafter Pocock, Time], in Politics, LANGuace and Time, supra note 30, at 233 (analyzing the role of tradition in societal conceptions of time); E.E. EvansPritchard, Nuer Time-reckoning, 12 Afr. J. INT'L INST. Afr. Languages \& Cultures 189 (1939) (arguing that oecological relations follow the meteorological dichotomy and economic life of the Nuer, thereby determining their more general social relations); Carol J. Greenhouse, Just in Time: Temporality 
order and stability out of a time of intense pain, sorrow, and mourning wars. Maintaining the League Council as an institution devoted to sustaining and renewing the Great Peace was the best way to prevent the degeneration of the League tribes back into chaos. One of the League Council's most weighty responsibilities, therefore, was to perpetuate the League of the Iroquois as one united people. Deganawidah charged the Council with this responsibility as a duty owed to future generations: "Be of strong mind, $\mathrm{O}$ chiefs! . . . Carry no anger and hold no grudges. Think not forever of yourselves, $\mathrm{O}$ chiefs, nor of your own generation. Think of continuing generations of our families, think of our grandchildren and of those yet unborn, whose faces are coming from beneath the ground."125

Deganawidah, according to the epic, directed the Council to favor peace, not war, with nations not confederated to the League. Nations that wished not to be at war and join the League were to be welcomed by the Iroquois under the Tree of Peace. ${ }^{126}$ For hostile tribes, Deganawidah had prescribed a nore active and aggressive response. The Council would send messengers to proclaim the Good News of Peace to the enemy tribe. "Listen to me!" an old sachem would cry in a loud voice to a village at war with the Iroquois, "I have cone to treat for peace with all the nations in these parts . . .."127 By such nessages of peace, a nation hostile to the Confederacy was to be invited into the Iroquois Longhouse. If the hostile nation accepted, "the land shall be beautiful, the river shall have no more waves, one may go everywhere without fear."128 If the hostile nation

and the Cultural Legitimation of Law, 98 YALE L.J. 1631 (1989) (analyzing the relationship between cultural conceptions of time and the organizations and management of legal institutions).

Societies exist in time, and conserve images of themselves as continuously so existing. It follows that the consciousness of time acquired by the individual as a social animal is in large measure consciousness of his society's continuity and of the image of its continuity which that society possesses; and the understanding of time, and of human life as experienced in time, disseminated in a society, is an important part of that society's understanding of itself-of its structure and what legitimates it, of the modes of action which are possible to it and in it. There is a point at which historical and political theory meet, and it can be said without distortion that every society possesses a philosophy of history-a set of ideas about what happens, what can be known and what done, in time considered as a dimension of societywhich is intimately a part of its consciousness and its functioning. How these images and ideas of time arise, function and develop may be studied as part of the science of society.

Pocock, Time, supra, at 233.

125. Anthony Wallace, The Death and Rebirth of the Seneca, supra note 3, at 42.

126. "The white roots of the Great Tree of Peace will continue to grow," Deganawidah had prophesied,

advancing the Good Mind and Righteousness and Peace, moving into territories of peoples scattered far through the forest. And when a nation, guided by the Great White Roots, shall approach the Tree, you shall welcome her here and take her by the arm and seat her in the place of council. She will add a brace or leaning pole to the longhouse and will thus strengthen the edifice of Reason and Peace.

Id. at $42-43$.

127. Id. at 43 .

128. Id. As explained by Professor Wallace:

The minimum purpose of the League was to maintain unity, strength, and good will among the Five Nations, so as to make them invulnerable to attack from without and to division from within. The native philosophers who rationalized the League in later years conceived also a 
refused, however, Deganawidah had prescribed that the Five Nations bring that nation into the circle of peace by force. ${ }^{129}$

Though the League Council could declare a war, it did not have the power to prosecute one. Iroquois political thought recognized that the passions of tribal leaders who had engaged in nortal coinbat were not likely to subside with the end of the conflict, and that calıner passions were required to make a firm and lasting peace. ${ }^{130}$ Thus, under the Iroquois system of government and its careful separation of powers, any sachem chief who desired to go on the warpath-for example, to avenge the murder of a kinsman by another tribe-was required to surrender his office. ${ }^{131}$ On the other hand, the League Council, as the peace-maintaining body for the Confederacy, exercised extensive control over making peace with other nations. Its powers in this arena included sending and receiving einbassies, entering into treaties of alliance, regulating the affairs of subjugated nations, receiving new members into the League, extending its protection over weaker tribes, and all other "needful ineasures" to proinote Iroquois prosperity and "enlarge their dominion." 132

maximum purpose: the conversion of all mankind, so that peace and happiness should be the lot of the peoples of the whole earth, and all nations should abide by the same law and be members of the same confederacy.

Id. at 42.

129. See PARKER, Constitution of the Five Nations, supra note 54, at 54. Parker's version of the "constitution" of the Five Nations contains the following procedure for declaring war.

When the proposition to establish the Great Peace is made to a foreign nation it shall be done in mutual council. The foreign nation is to be persuaded by reason and urged to come into the Great Peace. If the Five Nations fail to obtain the consent of the nation at the first council a second council shall be held and upon a second failure a third council shall be held and this third council shall end the peaceful methods of persuasion. At the third council the War Chief of the Five Nations shall address the Chief of the foreign nation and request him three times to accept the Great Peace. If refusal steadfastly follows the War Chief shall let the bunch of white lake shells drop from his outstretched hand to the ground and shall bound quickly forward and club the offending chief to death. War shall thereby be declared and the War Chief shall have his warriors at his back to meet any emergency. War must continue until the contest is won by the Five Nations ....

Id.

130. As Professor Tooker notes, the Iroquois, unlike Western societies, did not believe that the prosecution of war required the strong leadership of a supreme commander backed by a supreme legislative council.

They left matters of war to the war chiefs, who singly or in concert provided strong and innovative leadership as needed. The function of the League council was not to hinder this leadership, only to try to constrain it when it threatened to destroy the alliance between the five tribes and to encourage it when it promised to further the ends of the Confederacy as a whole. To the extent that it worked it was because war leaders were well aware of the advantages of unanimity as expressed in League councils and, it may be added, the advantage on certain occasions of not pursuing the same policy.

Tooker, supra note 3, at 316-17.

131. Morgan, supra note 3, at 67; see also Tooker, supra note 3 , at 316.

132. MoRGAN, supra note 3, at 63 . Professor Tooker speculates that because sachem name-titles appear so infrequently in the colonial records, the Iroquois League Council most likely sent the ablest speakers and politicians within the tribes to negotiate with foreign powers. "Understandably, then, the Iroquois who figure prominently in the historical record were not usually sachem chiefs-to the white negotiators a large and rather faceless body of men, as such deliberative bodies are apt to be to outsiders-but men who could exert influence." Tooker, supra note 3 , at 320 . 


\section{The Condolence Council in Iroquois Diplomacy}

The League Council's unifying and peacemaking roles illuminate the Iroquois' frequent use of Condolence Council rituals in League diplomacy. ${ }^{133}$ The Condolence Council's rich symbolic matrix of interconnected ritual systems provided Iroquois diplomats with a well-known and intensely practiced discourse of law and peace for treaty negotiations with Europeans and major tribal rivals. Wampum, for example, served as the central medium for the exchange of good thoughts between the two sides in the Condolence Council and figured prominently throughout the Encounter era treaty literature. In Iroquois treaty councils, as in Condolence Council rituals, wampum served communicative and connective functions, confirming the unifying sentiments spoken by the person presenting the treaty proposal. ${ }^{134}$ It was the primary means of establishing connection and maintaining the channel of communication between the two sides; in the context of the Condolence Council, wampum was the actual "word" containing the message of the ceremony. ${ }^{135}$ Iroquois diplomats confirmed the significance of wampum in treaty councils: "[Y]ou may know our words are of no weight unless accompanied with wampum ..."136 In addition, the emblematic designs commonly woven into wampum belts helped Iroquois diplomats recall the speeches associated with the wampum, thereby serving to "prop up their minds."137

Thus, wampum functioned as the primary symbolic means in Iroquois culture and diplomacy for establishing and maintaining the channel of communication between groups. For the Iroquois, the ritual exchange of wampum in the Condolence Council and in treaty negotiations with other nations served to underscore and solemnize the central message of their vision of law and peace-that different peoples could achieve peace and

133. For a description of the Condolence Council ritual, see supra text accompanying notes 36-49.

134. As Fenton explains, "[s]trings and belts of wampum served to affirm messages, to stress the import and truth of what was being said, and to convey the nature of the message." Fenton, Iroquois Treaty Making, supra note 36, at 17. According to Professor Druke, "[f]ormal acceptance of wampum was considered by the Iroquois to indicate that a message would be heeded or an agreement upheld. If the wampum's message was acceptable, the receiving party would retain the belt or string and would often reciprocate with their own wampum." Druke, supra note 11, at 88 . See also Foster, supra note 38 , at 104-08, on the function of wampum in treaty councils.

135. See, e.g., Druke, supra note 11 , at 88 ("Wampum played a large role in conveying, accepting, or rejecting messages and proposals at treaties.").

136. Id. at 89 (footnote omitted).

137. Fenton, Iroquois Treaty Making, supra note 36 , at 17. Druke has explained that when Iroquois diplomats "read" a belt, the purpose

was not primarily to explain the significance of individual emblems, though this sometimes was done, but rather to relate the speeches associated with the belt as a whole. . . . Moreover, modern studies suggest that several belts might have been associated at times with a certain agreement, any one of which might have served as sufficient stimulus to recall the entire narrative of transactions.

Druke, supra note 11 , at 89 (footnote omitted). 
friendship only by linking arms together in a reciprocal relationship of connection, communication, and solidarity. ${ }^{138}$

Iroquois diplomats also adapted the relational patterns established and maintained by the Condolence Council to fit the needs of their multicultural diplomacy. The Iroquois brought their allies, including colonial governors and officials, into an interdependent relation of reciprocity and connection by giving them names and places within the symbolic kinship system of the Iroquois. The newly "related" parties thereby assumed mutual duties and

138. Significantly, the essential meaning of an alliance in Iroquois political and legal discourse is derived from the phrase used by Iroquois diplomats to confirm a covenant of peace with another nation: "what was agreed upon, it joins their arms." Foster, supra note 38, at 110.

At the completion of the Wood's Edge welcome, the hosts lead the messengers "by the arm" (éyetshinettshi:neht "they will lead you by the arm") to the place of council where the greeting sequence continues. The messengers eventually gain the floor, producing the invitation wampum which, they say, has been leading them by the arm (ökhninẽtshinéhtaHne? "it has been leading us by the arm") to the present council fire-phrasing which underscores the perception of their role as relatively passive. They review the events of the council at which they were appointed, mentioning the date, place, and agenda of the proposed council. They literally speak for the chiefs: it is as though the chiefs were directly facing those on the other side of the fire. In a dramatic move they pass the wampum across to the hosts, saying as they do: "they now extend an invitation to you" (aetshinê:tsha" "they take you by the arm"). The pronominal reference here is unambiguously to the chiefs; it is they, not the messengers, who effect the invitation. They seem to have reached across the miles and to have taken the hosts directly by the arm to lead them to their council fire. This remarkable feat is made possible because of native beliefs about wampum, i.e., that it is the wampum rather than the messengers that is carrying the message. The council closes out with the hosts' accepting the invitation and commissioning the messengers to convey this information to the chiefs. From the point of view of the sender chiefs, wampum has functioned up to this point in the sequence as an instrument for establishing contact or opening a channel of communication.

Id. at 106-07 (footnotes omitted). 


\section{obligations of condolence and mourning, ${ }^{139}$ which the Iroquois diplomats carried out by adapting the rituals of the Condolence Council. ${ }^{140}$}

139. See Fenton, Iroquois Treaty Making, supra note 36, at 14. See also the description of the naming of the Governor of Maryland by the Iroquois at the 1744 Lancaster Treaty, reported by Witham Marshe, supra note 12, at 193-95:

After dinner, the interpreter informed the Governor and commissioners, "That as the Lord Proprietary and Govemor of Maryland was not known to the Indians by any particular name, they had agreed, in council, to take the first opportunity of a large company to present him with one: And, as this with them was a matter of great consequence, and attended with abundance of form, the several nations had drawn lots for the performance of the ceremony; and the lot falling on the Căhūgā nation, they had chosen Gāchrādōdőn, one of their chiefs, to be their speaker, and he desired leave to begin;" which being given, he, on an elevated part of the courthouse, with all the dignity of a warrior, the gesture of an orator, and in a very graceful posture, spoke as follows:

"As the Governor of Maryland has invited us here, to treat about our lands, and brighten the chain of friendship, the united Six Nations think themselves so much obliged to him, that we have come to a resolution, in council, to give the great man, who is proprietor of Maryland, a particular name, by which we nuay hereafter correspond with him: And as it hath fallen to the Cahugaes' lot in council to consider of a proper name for that chief man, we have agreed to give him the name of Tōcăry̆-hō-gōn, denoting Precedency, Excellency, or living in the middle, or honourable place, betwixt Asserigoa, and our brother Onas, by whom our treaties may be the better carried on."

And then, addressing hinself to his Honour the Governor of Pennsylvania, the honourable the commissioners of Virginia and Maryland, and to the gentlemen then present, he added:

"As there is a company of great men now assembled, we take this opportunity to publish this matter, that it may be known Tocary-ho-gon is our friend, and that we are ready to honour him, and that by such name he may be always called and known among us; and, we hope, he will ever act towards us, according to the excellence of the name we have now given him, and enjoy a long and happy life."

When the speech was ended, all the other chiefs expressed their assent, and great satisfaction at what was said to our commissioners, insomuch that they sent forth five several cries of approbation.

Id.

140. Instances of Iroquois diplomats condoling the deaths of non-Iroquois allies are recorded throughout the treaty literature. See, e.g., Fenton, Iroquois Treaty Making, supra note 36, at 20-21. One of the most frequently cited instances was recorded by Cadwallader Colden in 1660, when eight Mohawk chiefs visited Albany to condole English colonists murdered by the French. The speech, in which the Mohawk diplomat referred to the slain colonists as "our Brethren," contains a wealth of ethnographic detail on Encounter era Iroquois diplomatic customs and traditions:

Brethren, the Murder of our Brethren at Schenectady by the French grieves us as much, as if it had been done to our selves, for we are in the same Chain; and no Doubt our Brethren of New-England will be likewise sadly affected with this cruel Action of the French. The French on this Occasion have not acted like brave Men, but like Thieves and Robbers. Be not therefore discouraged. We give this Belt to wipe away your Tears.

Brethren, we lament the Death of so many of our Brethren, whose Blood has been shed at Schenectady. We don't think that what the French have done can be called a Victory, it is only a farther Proof of their cruel Deceit. The Governor of Canada sends to Onondaga, and talks to us of Peace with our whole House, but War was in his Heart, as you now see by woful Experience. He did the same formerly at Cadarackui, and in the Senekas Country. This is the third Time he has acted so deceitfully. He has broken open our House at both Ends, formerly in the Senekas Country, and now here. We hope however to be revenged of them. One Hundred of our bravest young Men are in Pursuit of them, they are brisk Fellows, and they will follow the French to their Doors. We will beset them so closely, that not a Man in Canada shall dare to step out of Doors to cut a Stick of Wood; But now we gather up our Dead, to bury them, by this second Belt.

Brethren, we came from our Castles with Tears in our Eyes, to bemoan the Bloodshed at Schenectady by the Perfidious French. While we bury our Dead murdered at Schenectady, we know not what may have befallen our own People, that are in Pursuit of the Enemy, they may be dead; what has befallen you may happen to us; and therefore we come to bury our Brethren at Schenectady with this third Belt. 
The metaphors and images of the Condolence Council provided a rich language and template for extending the vision of the Great Law of Peace first taught by Deganawidah. The Condolence Council provided Iroquois diplomats with a ritualized method for compounding "delicts with presents" and overcoming feuds between enemies. ${ }^{141}$ Iroquois diplomats could borrow the ritualized sequences of the Condolence Council when offering to bury the hatchet with a former enemy and by linking arms together through the mutual exchange of gifts of wampum and "good thoughts." Council rituals also availed Iroquois diplomats with a heartfelt means for dispelling grief by "removing the clouds and bringing back the Sun"142 so that the parties could be umited in "one mind." As Deganawidah himself had prescribed for all nations brought under the Tree of peace, all would now share and eat out of the same bowl together.

II

\section{The Iroquois Vision of Law and Peace as Revealed and AdaPted In Kiotseaeton's Presentation of TREATY TERMS AT Three RIVERS}

How did the indigenous tribal peoples of North America, with their radically divergent cultural backgrounds, languages, value systems, and traditions, seek to achieve peace and accommodation with the strange groups of European newcomers on the seventeenth and eighteenth century colonial frontier? The Treaty Council at Three Rivers in 1645 between the Iroquois, the French, and the French-allied tribes shows how the "Barbarian" diplomat Kiotseaeton sought to adapt and translate a North American indigenous

Great and sudden is the Mischief, as if it had fallen from Heaven upon us. Our Forefathers taught us to go with all Speed to bemoan and lament with our Brethren, when any Disaster or Misfortune happens to any in our Chain. Take this Bill of Vigilance, that you may be more watchful for the future. We give our Brethren Eye-Water to make them sharp sighted, giving a fourth Belt.

We are now come to the House where we usually renew the Chain; but alas! we find the House polluted, polluted with Blood. All the Five Nations have heard of this, and we are come to wipe away the Blood, and clean the House. We come to invite Corlear [New York's govemor], and every one of you . . . to be revenged of the Enemy, by this fifth Belt.

Brethren, be not discouraged, we are strong enough. This is the Beginning of your War, and the whole House have their Eyes fixed upon you at this Time, to observe your Behaviour. They wait your Motion, and are ready to join in any resolute Measures.

Our Chain is a strong Chain, it is a Silver Chain, it can neither rust nor be broken. We, as to our Parts, are resolute to continue the War.

We will never desist, so long as a Man of us remains. Take Heart, do not pack up and go away, this will give Heart to a dastardly Enemy. We are of the Race of the Bear, and a Bear you know never yields, while one Drop of Blood is left. We must all be Bears; giving a sixth Belt.

Brethren be patient, this Disaster is an Affiction which has fallen from Heaven upon us. The Sun, which hath been cloudy, and sent this Disaster, will shine again with its pleasant Beams. Take Courage, said he, Courage, repeating the Word several Times as they gave a seventh Belt.

Cadwallader Colden, The History of the Five Indian Nations 104-05 (Great Seal Books, Comell Univ. Press 1958) (1727, I747).

141. Fenton, Iroquois Treaty Making, supra note 36, at 14.

142. See supra text accompanying notes $45-49$. 
tradition of law and peace into a multicultural constitutional vision for ordering relations between the differing peoples of the early Encounter era. By evoking the language and metaphors of connection, solidarity, and trust found in the Iroquois Condolence Council and the Deganawidah epic, Kiotseaeton sought to transcend notions of "tribe, state, and empire" that divided the opposing sides at Three Rivers. ${ }^{143}$ Kiotseaeton's treaty proposal to the French and their allied tribes embodied the central message of the Iroquois vision of law and peace: through frequent dialogue, sharing, reciprocal exchanges of gifts and goodwill, and the mutualization of interests and resources, different peoples could attain "one mind" and "link arms together" under the Tree of Great Peace.

\section{A. Background to the Treaty at Three Rivers, $1645^{144}$}

From their imitial contacts with Europeans during the early seventeenth century, the Iroquois sought to control and direct the immensely valuable eastern North American fur trade through their own territories in what is now upper New York State. Aggressive pursuit of this policy created a series of trade wars with rival tribes throughout the colonial frontier during the early Encounter era. The Iroquois focused their energies primarily on control of the fur trade centered along the north-south corridor formed by the Hudson River Valley. This corridor, initially controlled by the Mahican tribe, supplied most of the furs to the newly-arrived Dutch merchants and traders in New Netherlands during the early years of Dutch colonial activity in North America. ${ }^{145}$ In 1628, the Mahicans, unable to repel Iroquois assaults and raids, fled to the Connecticut Valley, and the Iroquois became the new, dominant trading partner of the Dutch.

A steadily increasing fur trade between the Iroquois and the Dutch made their relationship, at least at first, mutually beneficial. ${ }^{146}$ However,

143. See Jennings, The Ambiguous Iroquois Empire, supra note 3, at 375.

144. For this section I have relied primarily on Robert A. Goldstein, French-Iroquois Diplomatic and Military Relations I609-170I (I969); Hunt, supra note 3; Jennings, The AMBIGUOUS IROQUOIs EMPIRE, supra note 3.

145. See Jennings, The Ambiguous Iroquois Empire, supra note 3, at 31.

146. See HuNT, supra note 3, at 33. There is evidence, however, that for both the Dutch and the Iroquois, there was a downside to the partnership. Dutch colonial officials deeply resented the Iroquois strategy of controlling other tribes' access to the traders at Albany. IR 1633, Kiliaen van Rensselaer, the patroon of the vast Rensselaerswich estate in New Netherlands, described the problems created by Iroquois controls in a letter to the Directors of the Dutch West India Company in Holland. The good patroon proposed the usual remedy of aggressive colonial expansion advocated by colonial officials whenever they encountered contending tribal interests in their pursuit of empire in North America:

[T] he savages, who are now stronger than ourselves, will not allow others who are hostile and live farther away and have many furs to pass through their territory, and . . . this would be quite different if we had stronger colonies . . . the Maquaas [Mohawks], who will not allow the French savages who now trade on the river of Canada and who live nearer to us than them [the French] to pass through to come to us, might through persuasion or fear sooner be moved to do so and ... from these savages more furs could be obtained than are bartered now in all New Netherland. This is only one of many things, but should be well considered as it can be accomplished in no other way than by establishing colonies. 
the Iroquois had great difficulty satisfying the unceasing demand of Dutch merchants, for whom the fur trade was "worth tons of gold."147 By the late 1630 s, the fur supply in the Hudson River Valley was largely exhausted from overhunting. The Iroquois recognized that they needed furs from Canada if they were to survive as major players in the frontier trading system. As one French observer remarked, "[T]he Iroquese, being unprovided with Beaver-skins to be given in exchange for Guns, Powder, Ball and Nets, would be starved to death, or at least obliged to leave their country."148

Beginning in 1615 , the Iroquois sought several times to make an independent arrangement for peace with the Hurons, France's major Indian trading partner, in order to acquire more beaver skins for the Dutch trade. The Mohawks, in particular, were most active in their attempts to divert the fur trade of the Canadian tribes away from Montreal and the other French trading stations to Iroquoia. As the Eastern Door of the Confederacy, the Mohawks were best situated and had the most to gain as the geographic and commercial middlemen in the colonial fur trade of eastern North America.

French colonial officials realized early on, however, that an unregulated diversion of furs to their Dutch rivals would threaten the collapse of France's fur-based trading empire in North America. France, therefore, utilized both diplomacy and pressure tactics to counter Iroquois efforts to establish trading alliances with the Canadian tribes. As a result, the French successfully blocked any formal alliance between their major client tribes and the Iroquois. ${ }^{149}$

Frustrated in their diplomatic efforts to get northern furs, the Iroquois adopted a new, more predatory strategy. They began to ambush and hijack French allied Indian canoes carrying furs along the St. Lawrence River. ${ }^{150}$

Jennings, The Ambiguous Iroquois Empire, supra note 3, at 49 (footnote omitted). See generally Bruce G. Trigger, The Mohawk-Mahican War (1624-28): The Establishment of a Pattern, 52 CANADIAN Hist. Rev. 276 (1971) (arguing that it is impossible to understand Dutch-Indian relations in New York State independently from French-Indian ones in Canada, and that the origin of the wars of the Iroquois may be traced to the Dutch arming of their Mohawk allies to further Dutch fur trade intcrests).

147. Jennings, The Ambiguous Iroquors Empire, supra note 3, at 51 (footnote omitted).

148. HuNT, supra note 3, at 35 (footnote omitted). As Hunt notes, Lahontan wrote some time after the Treaty of Three Rivers - his work was published in 1703-"but the position of the Iroquois ... had not changed." Id. at 35 n.27.

149. See id. at 70. The Mohawks had reasonable grounds to believe that the Canadian tribes would recognize the advantages of dealing with the Iroquois, as middlemen to the Dutch trade, over dealing directly with the French. Dutch merchants traded goods of better quality, for fewer furs, than did the French. The Indians of Canada could gain access to the preferred Dutch goods only through the Keepers of the Eastern Door of the Iroquois Confederacy, the Mohawks. See Jennings, The Ambiguous IROQUOIS EMPIRE, supra note 3, at 73-74. The theme of the Iroquois as middlemen for the Dutch appears throughout chapters 4 through 6 of Jennings' study on the Iroquois Covenant Chain alliance. See id. at $47-112$.

150. In 1642, France responded to this unwelcome disruption in the lifeblood of its North American trade-based empire with the construction of a fort on the River Richelieu. The Fort's primary mission was to prevent the Mohawks from hijacking the canoes and cargoes of France's Indian allies traveling along the St. Lawrence. Simultaneously, the French founded the settlement of Ville Marie on Montreal Island, "to serve as a sanctnary and mission for the Canadian Indians-and thus to protect their trade." Jennings, The Ambiguous Iroquois EMPIRE, supra note 3, at 56. 
By 1644 , the Iroquois, likely aided by a generous supply of Dutch arms and ammunition, ${ }^{151}$ had virtually shut off the entire St. Lawrence fur trade as far north as Quebec. A French Jesuit missionary reported in that year that only one Huron fleet out of four escaped capture by the Iroquois. ${ }^{152}$

In May of 1645, with the trade war threatening the financial collapse of their fledgling North American colonial empire, the French released two Iroquois prisoners as a gesture of goodwill. The two warriors had been captured by the Hurons in Huron territory. Though the Hurons had pleaded with the French Governor in Quebec to be allowed to "caress the prisoners a little,"153 (i.e., to torture and burn them), the French sent the two Iroquois prisoners home with a message that the French were ready to negotiate a peace. ${ }^{154}$ In response, the Iroquois sent a delegation headed by Kiotseaeton to French Canada. The delegation, which was also accompanied by Guillaume Cousture, a Frenchman captured by the Iroquois three years earlier, arrived at Three Rivers on July 5, 1645. ${ }^{155}$

\section{B. Kiotseaeton's Vision of Law and Peace Between the French and the Iroquois}

\section{Making Known the Thoughts of His Country}

Throughout his embassy at Three Rivers, Kiotseaeton employed the vivid metaphors and images of the Condolence Council ceremonies to communicate his message of peace and alliance. His plaintive cry for peace from the banks of the river, which served as his opening greeting to the French and Canadian tribes, was in fact a scaled down version of the inaugurating ceremony of the Condolence Council. This ceremony, practiced in its traditional form at the death of a chief, featured a procession of the

151. See id. at 55. Since arriving and establishing their colony in New Netherlands early in the seventeenth century, the Dutch had been leery of supplying their reluctantly-acquired trading partner, the Mohawks, with European muskets and arms. But the Iroquois apparently convinced the Dutch that the new French strategic moves threatened to reduce drastically the flow of Canadian furs to Albany. In 1643 , according to the evidence marshalled by Professor Jennings, the Dutch reversed their previous policy against selling arms to "wild men" like the Iroquois. See id. at 55-57.

152. HuNT, supra note 3, at 76. In obvious retreat, the French abandoned the new fortifications on the River Richelieu. With only 300 persons of ethnically French stock in Canada (as of 1642), including women and children, the French could ill afford to over-extend themselves at this early stage in their North American colonizing efforts. See Jennings, The Ambiguous Iroquois EmpIRE, supra note 3, at 91.

The trade war between the Iroquois and French caused great difficulties for France's Indian allies as well. The Hurons, France's major Indian trading partner, came under particularly vicious attack from the Iroquois. Father Isaac Joques, the French Jesuit missionary to the Canadian tribes, wrote in 1643, "[t]he design of the Iroquois . . . as far as I can see, is to take, if they can, all the Hurons; and, having put to death the most considerable ones and a good part of the others, to make them both but one people and only one land." Id. at 93 (footnote omitted).

153. HuNT, supra note 3 , at 77 .

154. Id.

I55. IroQuors Diplomacy, supra note 1 , at 137. 
"clearminded" "at the wood's edge" over the path to the house of the mourners.

[It] begins with the arrival of the messengers in the vicinity of the foreign council fire. Tradition prescribes that this be a point at which the cleared land around the settlement meets the forest .... Whatever precautionary purpose this may have served at a time when the sudden arrival of strangers could spell imminent danger, it also bears out the Iroquoian penchant for effecting a gradual rapproachement [sic] between alien groups. Protocol requires that a delegation from the host settlement repair to the spot where the visitors are waiting and perform a welcoming ceremony-itself a council in molecular form .... The two groups arrange themselves on opposite sides of a small fire built just for the duration .... . A speaker for the hosts expresses his side's gratitude that the messengers have arrived safely over the "long forest path" ... . There are many things, he says, that could have caused them to stumble and fall. ${ }^{156}$

The exigencies of forest diplomacy often required the modification of this and other ceremonies to fit the particular requirements of a potential treaty parley. ${ }^{157}$ Kiotseaeton's greeting from the bow of his boat can be seen as an adaptation of the Condolence Council tradition of the process of "gradual rapprochement between alien groups,"158 a rapprochement he hoped would lead to a lasting alliance of peace with the French and their allied tribes. He addressed the French, his traditional enemies, as "Brothers," the Iroquois kinship term for equals in a political and legal relationship. ${ }^{159}$ His opening words, in effect, sought to establish a close, symbolic connection and a channel of communication with his former enemies.

After Kiotseaeton communicated the good news of peace, he attended "a very cordial reception" 160 hosted by the French inside the fort. The "barbarian" drew directly from the metaphors of the Iroquois Condolence Council to toast his hosts:

I find much pleasure in your houses. Since I have set foot in your country, I have observed nothing but rejoicing. I see very well that he who is in the Sky wishes to bring to a conclusion a very important matter. The minds and thoughts of men are too diverse to fall into accord; it is the Sky that will combine all. ${ }^{161}$

156. Foster, supra note 38 , at 105.

157. See Fenton, Iroquois Treaty Making, supra note 36, at 28.

158. Foster, supra note 38, at 105.

159. See Iroquors Diplomacy, supra note 1, at 115, 120; see also id. at 128 ("As the mouth of his country, Kiotseaeton stood offshore in the bow of the boat draped in beads, hailing those at the landing as brothers, a kin term of equivalency.").

160. Id. at 138.

161. Id. On the significance and meanings of the "Sky" and "Sun" as metaphors for peace and "good thoughts" in Iroquois legal and political discourse, see infra text accompanying note 213-15. See 


\section{Consciousness-Raising}

The French sent a dispatch to Quebec to notify New France's governor, Charles Huault de Montmagny (whom the Iroquois addressed as "Onontio," meaning "Big Mountain"162) of the Iroquois embassy's arrival. Montmagny arrived a week later, and a large council was convened in the central courtyard of the French fort. ${ }^{163}$ On one side of the courtyard sat the French Governor and his people. "[A]s a mark of the affection they bore to the French," the Iroquois sat at his feet. ${ }^{164}$ Opposite the French and the Iroquois sat several of New France's allied Indian tribes, the Algonquins, Montagnais, and Attikanieques. The two other sides of the courtyard square were closed in by French and Hurons.

From the center of this stage, Kiotseaeton presented the proposed terms of a treaty of peace and alliance by means of an extensive performance of the Condolence Council rituals. He planted two poles in the center of the compound, between which he stretched a cord to hang his "words": the seventeen wanipum strings and belts that he had worn around his neck on his approach to the French camp. ${ }^{165}$ Kiotseaeton proclaimed the desire of the Iroquois to end all hostilities with the French and their allied tribes of Canada, ${ }^{166}$ and then burst into a song of peace, joined by the other Iroquois. ${ }^{167}$ As appears from Vimont's relation, Kiotseaeton's remarkable performance seized the imagination and attention of all who witnessed this display of Iroquois diplomatic ritual. " $[\mathrm{H}] \mathrm{e}$ began to sing; his countrymen responded; he walked about that great space as if on the stage of a theatre; he made a thousand gestures; he looked up to Heaven; he gazed at the Sun; he rubbed his arms as if he wished to draw from them the strength that moved them in war." 168

also Colden, supra note 140, at 105 (quoting a Mohawk diplomat's speech at Albany condoling those English colonists killed by the French: "Brethren, be patient, this Disaster is an Affiction which has fallen from Heaven upon us. The Sun, which hath been cloudy, and sent this disaster, will shine again with its pleasant Beams. Take Courage ....").

162. Jennings, The Ambiguous Iroquots EMPIRE, supra note 3, at 96. On the giving of names to colonial officials by the Iroquois, see supra text accompanying note 140 .

163. See Iroquors Diplomacy, supra note 1 , at 138.

164. Id.

165. Id. at 139 .

166.

Onontio, lend me ear. I am the mouth for the whole of my country; thou listenest to all the Iroquois, in hearing my words. There is no evil in my heart; 1 have only good songs in my mouth. We have a multitude of war songs in our country; we have cast them all on the Id. ground; we have no longer anything but songs of rejoicing.

167. The chanting of songs of peace derived from the Condolence Council is a recurrent feature of Iroquois treaty councils. Colonial records suggest that the Condolence Council Eulogy to the Founders of the Confederacy appears to have been sung at at least three important treaty councils: at Albany in 1694; Lancaster in 1744; and Onondaga in 1756. See Fenton, Iroquois Treaty Making, supra note 36, at 20. Other songs from the council appear throughout the treaty literature. See id. at $20 \& \mathrm{nn} .44-46$.

168. lroquors Diplomacy, supra note 1, at 139. On the use of imagination in lroquois diplomacy and its meanings for the multicultural world we encounter today, see infra Part II. 
After concluding this song of peace, Kiotseaeton presented each of the wampum strings to the French as a ritualized component in a series of stories representing the treaty terms. The first collar, presented to the French Governor, thanked the French for saving the life of Tokhrahenehiaron, an Iroquois prisoner who had been allowed to return to Iroquoia in May with the French message of peace and gifts to be distributed among the Iroquois' allied tribes as evidence of French desire for peace.

Kiotseaeton noted, however, that the French should have provided an escort, for had Tokhrahenehiaron died along the way, never returning, the channel of communication delivering the good news of peace would never have been established: "If his canoe had been upset; if the winds had caused it to be submerged; if he had been drowned, you would have waited long for the return of the poor lost man, and you would have accused us of a fault which you yourselves would have committed."169

Having rebuked the French for this diplomatic lapse, Kiotseaeton then demonstrated the more appropriate, Iroquois way of sending back prisoners with peace proposals. He tied the wampum to the French prisoner, Guillaume Cousture, who Kiotseaeton had brought back to the French at Three Rivers. He then reproached the Governor with the words of the second wampum belt:

It is this Collar that brings you back this prisoner. I would not have said to him, while he was still in our country: "Go, my Nephew; take a Canoe and return to Quebec." My mind would not have been at rest; I would always have thought over and over again to myself, "Is he not lost?" In truth, I would have had no sense, had I acted in that way. He whom you have sent back had all the difficulties in the world, on his journey. ${ }^{170}$

As Father Vimont related it, Kiotseaeton performed a humorous retelling of Tokhrahenehiaron's harrowing unescorted journey home from Canada, "in so pathetic a manner that there is no merry-andrew [i.e., clown] in France so ingemious as that Barbarian."171 Kiotseaeton, wrote Vimont, "took a stick, and placed it on his head like a bundle; then he carried it from one end of the square to the other, representing what that prisoner had done in the rapids and in the current of the water . . ."172

Kiotseaeton demonstrated how Tokhrahenehiaron had to portage his canoe and his baggage alone, "piece by piece," in the non-navigable parts of streams. He went "backward and forward" to show the journeys, windings, and turnings of the prisoner. "He ran against a stone; he receded more than

169. IroQuols Diplomacy, supra note 1, at 139.

170. Id.

171. $I d$.

172. Id. (footnote omitted). 
he advanced in his canoe, because alone he could not maintain it against the current. He lost courage, and then regained his strength."173

Kiotseaeton summarized his basic points on the proper way to treat prisoners returning home with gifts and a message of peace, reinforcing his underlying message that the Iroquois demanded recognition of their shared humanity by the French if the two peoples were to enter into an alliance of peace and friendship. "T know not where your thoughts were, to send a man back quite alone amid so many dangers. I did not do that. 'Come, my nephew,' I said to him whom you see before your eyes [Cousture]; 'follow me, I wisl to bring thee to thy own country, at the risk of my life." "174

This was consciousness-raising through storytelling, ${ }^{175}$ Iroquois-style. With his second wampum gift, Kiotseaeton sought to make a connection of goodwill by emphasizing that he had personally delivered the French prisoner back to his countrymen, accompanied by "words" signifying the Iroquois desire for a relationship of peace and "good thoughts."

At the same time, the "Barbarian" Kiotseaeton was ridiculing the French governor's poor efforts to establish a channel of commumication with the Iroquois. ${ }^{176}$ Through his pointed lecture, he sought to teach a basic

173. Id. at $139-40$.

174. Id. at 140 .

175. On consciousness-raising and storytelling as techniques in feminist and critical theories of law and jurisprudence, see generally Derrick BeLL, ANd We ARE Not SAVEd (1987) (elaborating on ten different forms of anti-black discrimination by telling ten separate stories in chapter form); Milner $S$. Ball, Stories of Origin and Constitutional Possibilities, $87 \mathrm{MrCH}$. L. Rev. 2280 (1989) (theorizing that each form of jurisprudence is inevitably connected to the cultural "story" within which law is made); Patricia A. Cain, Feminist Jurisprudence: Grounding the Theories, 4 BeRkeley WoMEN's L.J. 191 (1990) (retelling stories of lesbian individuals to ground feminist legal theory in the experiences of vomen); Richard Delgado, Storytelling for Oppositionists and Others: A Plea for Narrative, 87 Mich. L. REV. 2411 (1989) (discussing the very phenomenon of storytelling as a modem academic tool); Toni M. Massaro, Empathy, Legal Storytelling, and the Rule of Law: New Words, Old Wounds?, 87 Mrсн. L. REv. 2099 (1989) (elevating storytelling as an academic method of inductive education); Mari J. Matsuda, Looking to the Bottom: Critical Legal Studies and Reparations, 22 HARv. C.R.-C.L. L. Rev. 323 (1987) [hereinafter, Matsuda, Reparations] (encouraging scholars to listen to the stories of people experiencing discrimination before developing grand normative theories of justice); Mari J. Matsuda, Public Response to Racist Speech: Considering the Victim's Story, 87 MrcH. L. Rev. 2320, 2323 (1989) [hereinafter, Matsuda, Racist Speech] (retelling the stories of victims of racial harassment); Carrie Menkel-Meadow, Portia in a Different Voice: Speculations on a Women's Lawyering Process, 1 BERKeLEY WoMEN's L.J. 39 (1985) (discussing how the entry of women into the legal academy has led to an increase in the use of storytelling as an academic methodology); Martha Minow, Feminist Reason: Getting It and Losing It, 38 J. LeGAL EDuc. 47 (1988) (pursuing the perpetual critique initiated by feminist research while searching for practical justice rather than theory); Patricia Williams, The Obliging Shell: An Informal Essay on Formal Equal Opportunity, 87 Мicн. L. Rev. 2128 (1989) (retelling the story of minority set-asides in the case of the City of Richmond v. J.A. Croson Co., 488 U.S. 469 (1989), as part of a broader essay on formal equal opportunity); Patricia J. Williams, Alchemical Notes: Reconstructing Ideals from Deconstructed Rights, 22 HARV. C.R.-C.L. L. Rev. 401 (1987) (relating parables to a critique of the Critical Legal Studies movement); Robert A. Williams, Jr., Taking Rights Aggressively: The Perils and Promise of Critical Legal Theory for Peoples of Color, 5 LAW \& INEQuaLrTY 103 (1987) (introducing an analysis of the Critical Legal Studies movement by telling a Native American parable). The significance and meanings of consciousness-raising through story-telling in Iroquois diplomacy is further discussed infra Part WI.

176. On the uses of ridicule in Indian humor, see generally Williams, supra note 48, at 1024-27. 
lesson of Iroquois diplomacy to the French leader. As illustrated in the Condolence Council rituals of clearing paths, removing obstructions, and overcoming dangerous obstacles so that the Clearminded might deliver their condolence message to the Mourners, the Iroquois recognized the difficulty of making peace. The three bare words of rcquickening of the "wood's edge" ceremony (eyes, ears, and throat) represented the Mourning side's empathy and appreciation of the hardships encountered by the Clearminded side in bringing the messages of condolence and peace to the Mourner's Village. ${ }^{177}$ Kiotseaeton sought, through his harangue, to awaken the empathic capacity of the French by illustrating the hardships encountered by Tokrahenehiaron, ${ }^{178}$ and to instruct the French that the Iroquois expected to be treated as equals. This expectancy of reciprocal behavior, of sharing hardship in an empathetic relationship of peace and goodwill, ${ }^{179}$ was a core tenet of the Iroquois vision of law and peace. Equal status contact and the mutual exchange of the good news of peace were the fundamental assumptions of the Law of the Great Peace as taught by Deganawidah in Iroquois legal and political traditions. ${ }^{180}$

Kiotseaeton's consciousness-raising continued with his third wampum gift to the French, presented to show that the Iroquois had added "something of their own" to the Governor's presents, which had been carried to Iroquoia by the returned prisoner, Tokrahenehiaron. ${ }^{181}$ The Iroquois, Kiotseaeton explained, had supplemented the French gifts in order to secure the agreeinent of all of the Iroquois' many allied tribes "to arrest their hatchets, and to cause the weapons and paddles to fall from the hands of those who were embarking to go to war." 182 Sharing through the ritual exchange of gifts defined the basis of all reciprocal relationships of connection and solidarity in Iroquois culture. Gifts communicated the giver's

177. As Fenton notes, the Iroquois insisted on structuring relations with Europeans according to their own traditions and approaches. Europeans adopted such patterns only with difficulty.

In the crucible of Indian and White relations the patterns that had governed Iroquois life for centuries became compelling and forced the White people to approach the Indian in a highly ritualized way that was completely foreign to European ways and thinking. The Indian idea that alliances once made had to be constantly renewed was equally alien to European thought. Fenton, Iroquois Treaty Making, supra note 36, at 6.

178. On the uses of empathy in legal narratives, see generally Massaro, supra note 175, at 2101-02. Professor Massaro lists three aspects of empathic capacity:

1. The capacity to perceive others as having one's own goals, interests and affects;

2. imaginative experience of the situation of another; and

3. the distress response that accompanies this experiencing-which may (but not must)

lead to action to ease the pain of another.

Id. at 2101 (citing Lynne N. Henderson, Legality and Empathy, 85 MicH. L. Rev. 1574, 1579-82 (1987)). All three of these aspects are evident in Kiotseaeton's retelling of Tokhrahenehiaron's return journey home.

179. See supra note 140 (describing the 1689 Albany Conference at which the Iroquois mourned the deaths of the New York governor's subjects at the hands of the French).

180. See, e.g., PARKer, Constitution of the Five Nations, supra note 54, at 103; Richter, Ordeals, supra note 39 , at $16-18$.

181. See supra text accompanying notes 168-69.

182. Inoquois Diplomacy, supra note 1 , at 140. 
message and defined the relationship between the receiver and the giver. ${ }^{183}$ Each side anticipated a reciprocal exchange of gifts from the other, "present for present, word for word."184

With the third belt, then, Kiotseaeton demanded that reciprocity and equal status contact define all future relations between the parties. The French were to understand that the Iroquois were a powerful confederacy of tribes, and expected respect and appropriate gifts of friendship and goodwill as political and military equals. This recognition of a shared equality of status in a relationship of peace was one of the abiding principles of Iroquois political and legal traditions. ${ }^{185}$ A recognition of equality among the partners in an alliance provided a broad-based foundation for the open communication and dialogue the Iroquois regarded as necessary to the survival of a multicultural confederacy. ${ }^{186}$ Having so instructed the French about the principles that applied in a treaty with the Iroquois, Kiotseaeton moved on to the obstacles to reaching peace between the two sides.

\section{Clearing the Road}

In the Iroquois vision of law and peace, parties in a treaty relationship had to remove all barriers to connection, communication, and solidarity before they could establish and maintain the Great Peace. The fourth wampum gift presented by Kiotseaeton thus proposed a formal peace between the two sides through one of the most frequently cited metaphors of Iroquois diplomatic discourse: the Iroquois offered to bury the hatchet forever against their former enemies. "The 4th present was to assure us," according to Vimont's relation, "that the thought of their people killed in war no longer affected them; that they cast their weapons under their feet."187

183. See Druke, supra note 79, at 33; Fenton, Iroquois Treaty Making, supra note 36, at 17.

184. Fenton, Iroquois Treaty Making, supra note 36, at 12.

185. See supra text accompanying note 180 . The demand by Iroquois diplomats for recognition of their equal status in political relations with European colonists is a consistent refrain of the treaty literature. In 1768, for instance, a Mohawk speaker announced to English officials that "altho' we be thought at present an inconsiderable People, we are the head of a confederacy that has Powerful Alliances." Druke, supra note 79, at 32 (footnote omitted). In 1774, another Mohawk speaker warned the German settler, George Klock, "that they who know our Rank may Espouse our Cause as it is their Duty to do, and Convince the English that we have friends and Deserve attention." Id. (footnote omitted). On the importance of establishing equal status contact in multicultural relationships, see Richard Delgado, $A D R$ and the Dispossessed: Recent Books About the Deformalization Movement, 13 LAW \& SOC. INQUiRY 145, 152-54 (1988) (criticizing alternative dispute resolution as a method of avoiding rather than solving racial problems); Richard Delgado et al., Faimess and Formality: Minimizing the Risk of Prejudice in Alternative Dispute Resolution, 1985 WIs. L. REv. 1359, 1387-404 (describing procedures which suppress racial prejudice in alternative dispute resolution); Williams, supra note 32, at 704 (arguing that equal status contact helped affirm the humanity of indigenous peoples negotiating with settler states).

186. See supra notes 102-13 (discussing the Iroquois methods of assuring that all individuals were listened to seriously in deliberations on League policy and seeking "one mind" on important decisions).

187. IroQuors DiplomaCY, supra note 1 , at 140. 
In presenting the fourth wampum belt, by which he proclaimed to the French and their allied tribes that the cycle of mourning wars, raids and counterraids would cease, Kiotseaeton told a moving story. "I passed," he said, "near the place where the Algonquins massacred us last Spring."188 He tried to go by quickly when he came upon the site of this horrible crime against his fellow countrymen. On a mission of peace, he feared that the passions incited by his grief for his murdered kin would block his ability to communicate his message to the French and their allied tribes gathered at Three Rivers. He tried in earnest not to see the blood of his people that had been shed on that spot of ground. "I turned away my eyes for fear of exciting my anger; then, striking the earth and listening, I heard the voice of my Forefathers massacred by the Alguonquins." 189 Fortunately, the old ones, knowing Kiotseaeton's torment and seeing he was capable of revenge, called out to him in a loving voice:

My Grandson, niy grandson, be good; do not get angry. Think no longer of us for there is no means of withdrawing us from death. Think of the living,- that is of importance; save those who still live from the sword and fire that pursue them; one living man is better than many dead ones. ${ }^{190}$

Only after Kiotseaeton had heard his nuurdered kinsmen telling him to save and value the living was he able to pass by that place of death on the path to the fortress of his enemies. ${ }^{191}$

Wampum gifts five through nine sought to remove all other barriers that blocked the channels of communication between the Iroquois and the French and their allied Indians. Like the other gifts carried by the Iroquois diplomat to Three Rivers, these wampum collars drew upon the metaphors of the Condolence Council. The fifth belt, for example, "was given to clear the river, and to drive away the enenty's canoes, which might impede navigation." Kiotseaeton "made use of a thousand gestures" in delivering the words of this gift, "as if he had collected the waves and had caused a calm, from Quebec to the Iroquois country."192 The sixth collar was used to sniooth the rapids, waterfalls, and strong currents on the rivers connecting the Iroquois country to the French. ${ }^{193}$

The seventh belt was used "to produce a profound calm on the great Lake Saint Louys" that had to be crossed to reach the Iroquois territory. This belt served "to make it smooth as ice, to appease the winds, and to allay the anger of the waves." The Jesuit relation described how Kiotseaeton, "after having by his gestures rendered the route easy," tied a wanipum belt on the arm of a Frenchman. Thus linked, he then pulled the

188. Id.

189. Id.

190. Id. (footnote omitted).

191. See id. ("After having heard those voices I passed on, and I came to you ....").

192. Id.

193. See id. 
Frenchman "straight across the square," to illustrate the ease with which French canoes could now go to the Iroquois country. ${ }^{194}$

With the eighth belt, Kiotseaeton "performed the whole journey that had to be made on land." With his arms, he "felled trees; . . lopped off branches; .. . pushed back the bushes; . . . [and] put earth in the deepest holes." When finished, he said "[t]here . . . is the road, quite smooth and quite straight." He bent toward the ground to see if there were any more thorns on bushes, or any mounds which might block the path. Seeing none, he proclaimed: "It is all finished. We can see the smoke of our villages, from Quebec to the extremity of our country. All obstacles are removed." 195

With the clearing of the paths between Iroquoia and New France, the French were told by the ninth belt that they would always find fires lighted in all the Iroquois houses. Wood would be cut and waiting for them. The warming fires that welcomed them to the Iroquois country would never go out. Even in their own homes far removed from Iroquoia, the French would see the welcoming light of these fires. ${ }^{196}$

The theme of a welcoming fire continually burning bright was a recurrent metaphor of Iroquois political and legal traditions. It derived from the story of Deganawidah, who instructed the Iroquois to keep such a fire to lead other nations to Iroquoia and the Tree of Peace. ${ }^{197}$ In Condolence ceremonies, the fire was restored to renew the Confederacy, allowing Mourners to resume their duties on the Council of Chiefs. ${ }^{198}$

This middle sequence of belts presented by Kiotseaeton thus sought to convey a central message contained in the Iroquois vision of law and peace. Their purpose was to bury the hatchet, clear the rivers, smooth the rapids, calm the lakes, and remove all obstructions, even the tiniest thorns, between the Iroquois and the French, revealing the welcoming fire of peace. This symbolic revelation of the fire which would lead all nations to the Tree of Peace accorded with the traditions of Iroquois culture and diplomacy. In this North American indigenous vision of law and peace, relations of peace were established and maintained through purposive and frequent efforts to clear the channels of communication, connection, and solidarity between differing groups. ${ }^{199}$

194. See id. at 140-41 (footnote omitted).

195. Id. at 141 .

196. See id.

197. "The Smoke of the Confederate Council Fire shall ever ascend and pierce the sky so that other nations who may be allies may see the Council Fire of the Great Peace." Parker, Constitution of the Five Nations, supra note 54, at 31.

198. Id. at 112.

199. See Peter Wraxall, An Abridgment of the Indian Affairs 217 (Charles H. Mcliwain ed., 1915) ("You may say that Love \& Affection may be strong in Absence as when present but we say not. . . . Nothing more revives \& enlivens affection than frequent Conferences."); see also Fenton, Iroquois Treaty Making, supra note 36, at 6 (describing the Indian idea that alliances had to be constantly renewed). 


\section{Linking Arms Together}

Kiotseaeton's next series of wampum gifts proposed the principal treaty terms, defining an alliance grounded in a web of interdependence, solidarity, and trust between the Iroquois and the French and their allied tribes. Shared benefits and cooperation, rather than predatory competition and debilitating war, would characterize all future relations between the parties. 200

The tenth wampum collar was the priniary treaty belt presented by Kiotseaeton to the French at the Three Rivers conference. Described as "extraordinarily beautiful" by the Jesuit, Vimont, this belt was given "to bind us all very closely together."201

He took hold of a Frenchman, placed his arm within his, and with his other arm he clasped that of an Alguonquin. Having thus joined himself to them, "Here," he said, "is the knot that binds us . . . . Even if the lightning were to fall upon us, it could not separate us; for, if it cuts off the arm that holds you to us, we will at once seize each other by the other arm."202

Having declared the Iroquois desire to create a firm and lasting alliance by linking arms with the French and their allied tribes, Kiotseaeton further dramatized the belt's message of peace and solidarity: "[and] thereupon he turned around, and caught the Frenchman and the Alguonquin by their two other arms, - holding them so closely that he seemed unwilling ever to leave them." ${ }^{203}$ A great peace would be formed by this linking of arms together. Linking arms firmly together was a principal metaphor deployed by Iroquois diplomats throughout the treaty literature of the Encounter era. "[W] hat was agreed upon, it joins their arm," was the phrase used generally in Iroquois diplomatic discourse to confirm a treaty of peace and trust with different peoples. ${ }^{204}$

200. In this sense, the treaty terms proposed by Kiotseaeton echo the distinctive characteristics of the type of long-term "relational contract" described and analyzed in the works of Law and Socicty scholars, most prominently Professor Macneil. See, e.g., Ian R. Macneil, Contracts: Adjustment of Long-Term Economic Relations Under Classical, Neoclassical, and Relational Contract Law, 72 Nw. U. L. REv. 854 (1978); Ian R. Macneil, Economic Analysis of Contractual Relations: Its Shortfalls and the Need for a "Rich Classificatory Apparatus," 75 Nw. U. L. REv. 1018 (1981); Ian R. Macneil, Relational Contract: What We Do and Do Not Know, 1985 WIs. L. Rev. 483. Law and Society contract scholarship and its relation to the Iroquois vision of law and peace is discussed infra Part III.

201. Iroquois DiplomaCY, supra note 1, at 141.

202. Id. At Albany in 1679, the Mohawks performed nearly the same ritual with Govcrnor Edmund Andros of New York. According to the report of the treaty, the Mohawk sachems told the Governor "that they belong to his Government \& desire the Covenant Chain may be strong \& binding, then they Take hold of Arm saying here is two of us . . . [they] desire their Armes may remain fast together \& that there may be no Misunderstanding." Richter, Rediscovered Links, supra note 3, at 56 (footnote omitted).

203. Iroquois Diplomacy, supra note 1 , at 141 .

204. Foster, supra note 38 , at 110. 
By linking arms together, the two sides would form a "circle in security, peace and happiness," 205 as the Five Nations of Iroquois theinselves had done at Deganawidah's urging. ${ }^{206}$ According to the ancient traditions of law and peace informing Kiotseaeton's presentation of treaty terms at Three Rivers, firm bonds of trust and solidarity are created whenever different peoples agree to link arms together in a circle of security, peace and happiness. ${ }^{207}$ This basic inetaphor of Iroquois life and culture could be readily adapted by skilled League diplomats to imagine the founding of the Confederacy itself, a treaty of trade and friendship between the Iroquois and French, or the Covenant Chain constitution with the English colomies which emerges in the late seventeenth century treaty literature. ${ }^{208}$

Kiotseaeton next presented the eleventh belt, which invited the French and their allied Indians to eat with the Iroquois. ${ }^{209}$ This invitation symbolized the sharing of the resources of their hunting grounds through trade and reciprocal exchange of use privileges. The words of this belt echoed the epic of Deganawidah as well, at whose direction the League Council had resolved to open their individual tribes' hunting grounds as a commons benefiting all the nations of the confederacy. ${ }^{210}$ Stressing again, "with appropriate gestures," that the "road is cleared; there is no longer any danger," Kiotseaeton told his hosts: "Our country is well stocked with fish, with venison, and with game; it is everywhere full of deer, of Elk, of beaver. Give up ... those stinking hogs that run about your houses, that eat nothing but filth; and come and eat good meat with us."211

Eating from the same bowl together was one of the most common metaphors of Iroquois diplomacy. It meant that the League and its allies gave each other the reciprocal right to share hunting grounds and to freely trade with each other the resources derived from the joined lands. In the

\footnotetext{
205. PARKer, Constitution of the Five Nations, supra note 54, at 102.

206. See supra text accompanying note 121.
}

207. Such adaptation was characteristic of Iroquois diplomats, finding its most refined application in the Covenant Chain constitution. See Fenton, Iroquois Treaty Making, supra note 36, at 28; supra text accompanying note 157. For example, at a 1691 meeting in Albany between Governor Henry Slaughter and the Five Nations, the Iroquois told of the establishment of the "Covenant Chain of Friendship" between the Confederacy and New York upon the first arrival of Englishmen "in this Country." This Chain, they stated, "has always been kept inviolable, both by the Bretheren \& us in which Covenant it was agreed That whosoever should hurt or Prejudice the one would be Guilty of Injuring all of us, being comprehended in one Common League." Richter, Rediscovered Links, supra note 3 , at 49 (footnote omitted).

The themes of solidarity, connection and mutualization of interests were invoked by another Iroquois speaker, Sadeganabtie, at Albany in 1694, who emphasized the importance of "[k]eeping [the] Chain firm and inviolable [and] all that are linked therein. ... The least Member cannot be touched, but the vhole Body must feel and be sensible; if therefore an Enemy hurt the least part of the Covenant Chain, we will join to destroy that Enemy, for we are one Head, one Flesh, and one Blood." Fenton, Iroquois Treaty Making, supra note 36, at 22 (footnote omitted).

208. See supra note 207 and text accompanying notes 13-30.

209. IroQuors Diplomacy, supra note 1 , at 141 .

210. PARKer, Constitution of the Five Nations, supra note 54, at 103.

211. IROQUOIS DIPLOMACY, supra note 1 , at 141 (footnote omitted). 
Iroquois vision of law and peace, the resources of the lands belonging to the parties to a treaty were recognized as being held for the benefit of all nations brought under the Tree of Peace. A treaty created common, shared rights in the territories and resources of the parties, including the right and duty to trade with each other. In fact, to the Iroquois, peace and trade were one and the same thing, as each involved the exchange of "good thoughts." 212 For this reason, the Condolence ceremonies always ended with a great social feast at which the parties ate together and celebrated the renewal of the Confederacy and the sharing of resources that supported and sustained the Great Peace.

Kiotseaeton next lifted the twelfth belt high above his head, "to dispel the clouds in the air, so that all might see quite plainly that our hearts and theirs were not hidden; that the Sun and the truth might light up everything." 213 Again, Kiotseaeton was borrowing from a Condolence Council ritual, in which the Clearminded remove the "mist" from the eyes of the Mourners, "so that the sky may be clear" and they might now be able to "see the sun rising over the trees." 14 In the Iroquois vision of law and peace, the parties to a treaty covenanted to link arms together to share their resources and their sorrows. They agreed to remove the "mist" from each other's eyes, thereby revealing the Sun in the Sky which shines truth on the minds and thoughts of all peoples. ${ }^{215}$

\section{Rejoicing for the Good of Peace}

Kiotseaeton concluded the treaty conference at Three Rivers with the presentation of several closing wampun collars touching collateral issues in the new alliance. ${ }^{216} \mathrm{He}$ then expressed concern that the Hurons might jeop-

212. As one seventeenth century Iroquois speaker told the English at Albany, "Trade \& Peace we take to be one thing ...." Richter, Rediscovered Links, supra note 3, at 53. In earlier meetings with the Dutch, a Mohawk speaker told the magistrates of Albany that they had

been here before and made an alliance. The Dutch, indeed, say we are brothers and are joincd together with chains, but that lasts only as long as we have beavers. After that we are no longer thought of, but much will depend upon it when we shall need each other.

Id. at $53 \mathrm{n} .18$ (citation omitted).

Similarly, European Renaissance and Enlightenment era writers on the Law of Nations regarded the right to trade with other nations a part of a binding natural law governing the relations between nations. See, e.g., Williams, supra note 8, at 101-02 \& n.166.

213. Iroquois DiplomaCY, supra note 1 , at 141 .

214. PARKER, Constitution of the Five Nations, supra note 54, at 112.

215. See supra text accompanying notes $36-44$.

216. The thirteenth belt sought to remind the Hurons of efforts by the Iroquois to negotiate an earlier peace with them in good faith. "What made you change your minds?" Kiotseacton asked plaintively. IRoQuoIs Diplomacy, supra note 1, at 141. The fourteenth belt renewed the Iroquois offer of peace and trade with the Hurons, urging them "to make haste to speak." In front of the French and the Alguonquins, Kiotseaeton asked the Hurons to go directly with their trade to the Iroquois country, and "to pass by that of the Alguonquins and of the French," opening up a direct channel of communication and trade with the Iroquois. Id.

The fifteenth gift sought the return of the Jesuit missionaries to Iroquoia. Id. at 142. The sixteenth asked the French and their allies to receive and protect the Iroquois when they came into their country. 
ardize the newly-concluded peace: "I am going to spend the remainder of the summer in my country in games, in dances, in rejoicing for the good of peace; but I fear that, while we dance, the Hurons will come to taunt and importune us." 217

Father Vimont summed up the impact of Kiotseaeton's speech on the assembly. "Every one admitted that this man was impassioned and eloquent," recalled Vinont. "He sang some songs between his gifts; he danced for joy; in a word, he showed himself to be a very good Actor, for a man who has learned but what nature has taught hirn, without rule and without precept.".218

The formal French reaction to Kiotseaeton's peace proposals, which came after two days, responded to the gifts of the Iroquois in a discourse they were certain to appreciate. "[F]ourteen gifts, all of which had their meanings and which carried their own messages" were presented to Kiotseaeton and his embassy, who responded "with great marks of satisfaction ... manifested by three loud cries, uttered at the same time from the depths of their chests, at each word or at each present that was given them."219 On the eve of his departure, the Jesuits entertained Kiotseaeton and his company, and presented more gifts, including some tobacco and a "handsome calumet or pipe."220 Kiotseaeton gave a toast, which echoed the themes of his opening remarks at the wood's edge when he had first approached the French settlement at Three Rivers:"221 "When I left my country, I gave up my life and exposed myself to death, so that I am indebted to you for being still alive. I thank you that I still see the Sun."222

Kiotseaeton bid adieu that night at the priest's house, with a promise that the French would hear from the Iroquois very soon. The channels of communication and connection having been cleared, Kiotseaeton was cer-

The Iroquois, Kiotseaeton explained, had only gone to war on the basis of their fears of French hostility and the necessity of showing resolve:

When we brought back your prisoners, some years ago, we thought that we were your friends, and we heard arquebus and cannon shots whistling on all sides of us. That frightened us; we withdrew; and, as we have courage for war, we took the resolution to give proofs of it the following Spring; we appeared in your land, and captured Father le Jogues, with some Hurons.

Id. (footnote omitted).

The final gift was sent by Father Jogues' adopted aunt in Iroquoia, commemorating a name given a Mohawk captive. See id. Conforming to the basic pattern of the Condolence Council ceremonies, a great dance and feast that included all the parties followed. See id.

217. See id.

218. Id.

219. Id. at 143 (footnote omitted).

220. Id. at 143-44.

221. See supra text accompanying note 2 .

222. Iroquois DiplomacY, supra note 1, at 144. Having announced his debt to his hosts, Kiotseaeton continued on in his thanks to the French: "I thank you for having received me well; I thank you for having treated me well. I thank you for all the good conclusions to which you have come; all your words are very agreeable to us." Always the diplomat, Kiotseaeton continued on, "I thank you for your presents; you have covered us from our feet to our heads." He thanked his hosts for the calumet pipe "gladdened ... . with the flavor of a plant that is very pleasing to us." Id. 
tain that the words of this good news would reach Iroquois, even if some disaster should prevent Kiotseaeton himself from returning personally to deliver the message of peace. ${ }^{223}$ Peace, according to Iroquois legal and political traditions, was a feeling as much as a reality, a matter of good thoughts between different peoples. ${ }^{224}$ Kiotseaeton's conviction that his countrymen had a foretaste of the good news generated by the treaty council at Three Rivers reflected this general Iroquois belief: the feeling of peace between the Iroquois and the French and their allied tribes could already be felt by his countrymen in Iroquoia.

\section{I Am One of Your Relatives}

The next day, Kiotseaeton and his small party left Three Rivers. The events upon departure indicate that a successful treaty relationship of mutual interdependence and the sharing of good thoughts had been achieved. The French had presented Kiotseaeton with appropriate gifts to cement the relationship. The French also had learned the lesson respecting the provision of escorts for returning Iroquois messengers with gifts. Governor Montmagny was reported by Father Vimont to have provided the services of "two young French lads" to help the Iroquois "take back their canoes and their presents."225 Most importantly, the symbolic connection of kinship and solidarity had been established between the two sides. "Adieu my brothers;" Kiotseaeton shouted to the French and their allies while standing on the banks of the river, "I an one of your relatives. I am going to carry back good news to our country."226

As Kiotseaeton and his party pushed off from shore, the Canadian Indians fired off a salvo of musketry, and the French honored the embassy with a cannon shot, an Old World innovation brought to the forest diplomacy of the New World. "Thus ended their Embassy," reports Father Vimont. "May God cause all this to succeed for his greater glory."227

\section{The Conclusion to the Treaty at Three Rivers}

The Treaty of Peace at Three Rivers was concluded fornially by the parties on September 20, 1645. Although neither the French representatives nor Kiotseaeton, who negotiated only on behalf of the Mohawk nation, ${ }^{228}$

223.

Even if we are wrecked in the waters, even if we are quite submerged, I think that the Elements will in some way bear witness to our countrymen of your kind deeds; and I am convinced that some good genius has gone before us, and that our countrymen already have a foretaste of the good news that we are going to bring them.

Id. (footnote omitted).

224. See supra text accompanying note 72 .

225. Iroeuois Diplomacy, supra note 1 , at I44.

226. Id.

227. Id.

228. See supra note 25. 
could bind any nation beyond their own to the new treaty, ${ }^{229}$ the French client tribes began to arrive at Three Rivers the following month, with "orders from the whole of their country to enter into full negotiations for peace . . .."230 They were followed shortly thereafter by four Iroquois "ambassadors" who had come to ratify the treaty of peace negotiated by Kiotseaeton. ${ }^{231}$

Although the language and procedures governing the fornation of this multicultural alliance originated in a North American indigenous vision of law and peace, Father Vimont, the primary chronicler of the events at Three Rivers, did not recognize the peace as an achievement realized through indigenous North American diplomatic skill and wisdom. He could only see and interpret the events at Three Rivers according to meanings originating in his own European-derived understanding of the treaty. ${ }^{232}$ Vimont concluded his relation of Kiotseaeton's embassy and the treaty subsequently concluded at Three Rivers in 1645 with the following prayer:

Praised forever be the God of Gods; may his Name be glorified in all the Countries of the Earth. If these Barbarians-who, because they know not God, have hardly any equity or stability - do not disturb this peace, ... it will be possible to go and suffer for JESUS CHRIST in a great many nations. ${ }^{233}$

III

\section{A Chain of Meanings: The Peace at Three Rivers and the Multicultural World We Encounter}

TODAY

How are we, who live in our own multicultural world of diversity and conflict, to find and understand meaning for ourselves in the early seventeenth century North American indigenous vision of law and peace proclaimed by Kiotseaeton at Three Rivers? Do the words spoken by an Encounter era "barbarian" diplomat speak directly to us today? The peace treaty negotiated by Kiotseaeton at Three Rivers ultimately failed in linking

229. See Iroquors Diplomacy, supra note 1, at 143 (regarding the inability of the French to directly bind allied tribes not present to the treaty).

230. Id. at 145-46.

231. See id. at $\mathrm{I} 46$.

232. See id. at 134-35.

233. Id. at 153. The multicultural peace betwcen the Iroquois, the French, and the Indian tribes of Canada lasted only a few years. See Jennings, The Ambiguous Iroquors Empire, supra note 3, at 92. The reasons for the failure of the Treaty of Three Rivers and the resumption of the war between the two sides are intensely debated by historians of the Encounter era, but few have ascribed it solely to the Indians' lack of "equity or stability." In fact, Professor Hunt writes that within a year of the Three Rivers Treaty, the Hurons sent to Montreal the "greatest fur fleet ever to descend the Ottawa." HunT, supra note 3, at 84 . Despite the earlier agreament by France and its allied tribes to share in the beaver trade with the Iroquois, the League received, in the words of Professor Hunt, "not so much as one skin." Id. Hunt assigus the subsequent outbreak of the Beaver Wars to the breach by the French and the Hurons. Id. at 85-86. 
together the Iroquois and the French and their allied tribes. But the Iroquois persisted in their desire to comply with Deganawidah's command to bring other nations under the Great Tree of Peace. The League responded to the breakdown of the treaty at Three Rivers by linking arms with the British colonies through the Covenant Chain, a multicultural alliance informed by the same vision of law and peace proclainued by an Iroquoian diplomat in the treaty at Three Rivers in 1645 .

Kiotseaeton's embassy to the French and their allied tribes in 1645 demonstrates that American Indian peoples have confronted the challenge of achieving law and peace in a world of hunran diversity and conflict since their first recorded encounters with Europeans. The multicultural constitutional vision of the Iroquois, articulated in the language and metaphors of Kiotseaeton's early seventeenth century diplomatic mission, and realized later in the century in the construction of the Covenant Chain alliance, represented one North American indigenous response to this challenge. Such a response, I believe, does speak to us today with meaning and relevance as we confront our own unique set of problems in achieving law and peace in our multicultural world. Through their successes, as well as their failures, Indians like the Iroquois engaged in the intensely human process of trying to understand how different peoples are brought together in relationships of peace, solidarity, and interdependence.

In this Part of the Article, I explore the relevance of the Encounter era Iroquois multicultural constitutional vision for contemporary theoretical understandings of the problems of achieving law and peace among different peoples. As I try to show, the writings of a diverse range of theorists-the anthropologist Clifford Geertz, the philosopher Richard Rorty, and scholars in the fields of critical race theory, feminist legal theory, legal realism, law and society, and critical legal studies-can be drawn upon to provide a prism that suggests ways in which the Iroquois vision of law and peace speaks to today's problems of living and dealing with different peoples.

\section{A. Link One: Solving the Puzzles of Translation}

The first challenge which Kiotseaeton faced at Three Rivers was making his words and ways of speaking understood by the French and Canadian Indians. When he appeared initially "at the wood's edge" of Three Rivers, he declared "I come therefore to enter into the designs of the French ... . . I come to make known to you the thoughts of all my country."234 We now understand that this phrase encompassed the basic purpose of Iroquois diplomacy. It was inherited from the Deganawidah epic and the founding of the Confederacy, and it informed the emergence of the Covenant Chain: the creation of alliances with other peoples by sharing the good thoughts of peace. Kiotseaeton sought to enter into the designs of the French and their

234. IroQuois DiPlomacY, supra note 1, at 138; see also supra text accompanying notes 1-2. 
allied tribes, and to make known the Iroquois' own thoughts of peace, through the rituals of the Condolence Council. In Iroquois culture, these rituals served to establish and maintain communication and connection between differing and once-alienated groups. Kiotseaeton's declaration at the wood's edge of the French settlement was in essence an offer to perform the council rituals for the French and their allied tribes, so that the two sides would be linked together, each sharing in the other's "designs."

In Iroquois diplomacy, the Condolence Council rituals were relied on in translating the "good thoughts" of peace between groups desiring to enter into an alliance. The illuminating work of the contemporary cultural anthropologist Clifford Geertz provides a useful prism for viewing the relevance of Kiotseaeton's reliance on these sacred rituals to our own contemporary understandings of how we make our thoughts and meanings known to others in a multicultural world.

A prominent theme frequently addressed in Geertz's work on achieving intercultural understanding focuses on the problem of learning how meaning in one system of expression is expressed in another. Geertz continually urges us to recognize that the differences we perceive separating ourselves from other strange, alien sorts of people will normally have more to do with solving, in his words, the "puzzles of translation," than with making distinctions about "civilized" and "less-civilized" cultures. ${ }^{235}$

This problem of learning how meaning in one system of expression is expressed in another is one of the most difficult tasks we confront in a multicultural world. ${ }^{236}$ Addressing the problem requires, in Geertz's language, a "cultural hermeneutics": a way of understanding and linking meanings in a world of hunian diversity and conflict. ${ }^{237}$ According to this type of multicultural interpretive perspective:

The problem of how a Copernican understands a Ptolemaian, a fifth republic Frenchman an ancien régime one, or a poet a painter is seen to be on all fours with the problem of how a Christian understands a Muslim, a European an Asian, an anthropologist an aborigine, or vice versa. We are all natives now, and everybody else not immediately one of us is an exotic. What looked once to be a matter of finding out whether savages could distinguish fact from fancy now looks to be a matter of finding out how others, across the sea or down the corridor, organize their significative world. ${ }^{238}$

\footnotetext{
235. GeERTZ, LOCAL KNOWLEDGe, supra note 54, at 151.

That thought is spectacularly multiple as product and wondrously singular as process has thus not only come to be a more and more powerful animating paradox within the social sciences, driving theory in all sorts of directions, some of them reasonable, but the nature of that paradox has more and more come to be regarded as having to do with puzzles of translation, Id. with how meaning in one system of expression is expressed in another ....

236. See id. at 3-16, 147-63.

237. Id. at 151.

238. Id.
} 
The theoretical problematics of elaborating a cultural hermeneutics in the contemporary social sciences share many similarities with the very practical difficulties encountered by Kiotseaeton in approaching the wood's edge of a hostile, alien settlement. The opening words of peace spoken by Kiotseaeton at the Treaty Council at Three Rivers demonstrate that Iroquois diplomats of the Encounter era understood clearly that achieving law and peace among different peoples involves first and foremost a process of finding out how others order their significative world; literally, we must enter into their designs, and make our own thoughts known to them.

In Iroquois diplomacy, this first step in solving the puzzles of translation encountered in a world of human diversity and conflict was taken by utilizing the rituals, metaphors, and rich symbolic language of the Condolence Council. An example of this reliance on the Council ceremonies is found in Kiotseaeton's toast, delivered upon his welcome into the houses of the French at Three Rivers: "The minds and thoughts of men are too diverse to fall into accord; it is the Sky that will combine all."239 The metaphor of the "Sky," drawn directly from the Condolence Council ceremonies, imagines a world of human solidarity achieved by "removing the clouds" from our normal discordant ways of thinking. ${ }^{240}$ It was one of a host of imaginative and moving metaphors on which Iroquois diplomats could draw in their efforts to enter into the designs of other peoples and share with them in the good thoughts of peace.

The ritual exchange of highly valued gifts of wampum, accompanied by the "words" drawn from the council tradition, illustrates the emphasis Iroquois diplomacy placed on a shared understanding between once-alienated groups. Each gift was accompanied by a story illustrating the Iroquois understanding of how parties in a relationship of peace should act towards one another. The expectation that the other party would reciprocate with gifts, as the French did at Three Rivers, signified that both parties had reached a rough mutual understanding of their reciprocal obligations. The ritual exchange of gifts performed according to the rituals of the Condolence Council, in other words, served as a translating device to assure that each party shared in the thoughts of the other, and that each would be incorporated into the other's designs. As the contemporary anthropologist Geertz has recognized, intercultural understanding can only be achieved by first confronting the puzzles of translation that separate us from other strange and alien-seeming peoples. ${ }^{241}$ In the Iroquois vision of law and peace, the parties to a treaty sought to solve the puzzles of translation that separated them by utilizing the metaphors and rituals of an ancient ceremony to enter into each other's designs and make known to each other the good thoughts of peace.

239. IroQUOIs Diplomacy, supra note 1, at 138; see supra note 161 .

240. See supra text accompanying note 214.

241. See Geertz, Local KNowhedge, supra note 54, at 9. 


\section{B. Link Two: Using Our Imagination}

Iroquois culture placed great emphasis on establishing and maintaining relations between groups of people who saw themselves, and treated eacli other, as connected at a most basic level of liuman solidarity. A fundainental lesson taught by the Deganawidah epic, and reinforced by the reciprocating rituals of the Condolence Council, was that relations of trust and interconnectedness were most effectively sustained by the sharing of sufferings between differing groups. Kiotseaeton's drannatic portrayal of the hardships suffered by Tokhrahenehiaron, the prisoner released by the French and returned to Iroquoia, illustrates low League diplomats sought to teach this central lesson to their potential treaty partners. ${ }^{242}$ His re-enactment of his countryman's harrowing journey home was a highly imaginative effort to connect the French to the pain, humiliation, and fear experienced by an Iroquois. By contrasting his own conduct in returning the French hostage Cousture (whom he called his "Nephew") to Three Rivers, he reinforced the basic lesson that partners connected in a treaty relationship should recognize each other as fellow human beings with a similar capacity for suffering.

A contemporary theoretical understanding of this Iroquois emphasis on the sharing of sufferings as the foundation of an alliance in a multicultural treaty relationship is provided by the recent work of the North American philosopher, Richard Rorty. In his 1989 book, Contingency, Irony, and Solidarity, ${ }^{243}$ Rorty stresses the importance of the imagination in realizmg a "liberal utopia" of moral progress "in the direction of greater human solidarity."244 Rorty defines his vision of human solidarity "as the ability to see more and more traditional differences (of tribe, religion, race, customs, and the like) as unimportant ... [and] the ability to think of people wildly different from ourselves as included in the range of 'us." "245 In Rorty's liberal utopia, therefore, human solidarity is seen "not as a fact to be recogmized by clearing away 'prejudice' ... but, rather, as a goal to be achieved. It is to be achieved not by inquiry but by imagination, the imaginative ability to see strange people as fellow sufferers. Solidarity is not discovered by reflection but created."246

Rorty's contemporary insight that human solidarity is created by the imaginative ability to see strange peoples as fellow sufferers provides us with a useful prism for understanding the meanings conveyed by Kiotseaeton's compelling performance of Tokhrahenehiaron's hardships. Like the Condolence Council ceremonies which Deganawidah instituted to end the mourning wars and unify the Five Nations, Kiotseaeton's story, in

242. See supra text accompanying notes 169-75.

243. Richard Rorty, CoNTINGENCY, IRONY, aNd Solidarity (1989).

244. Id. at $\mathrm{xvi}, 192$.

245. Id. at 192 .

246. Id. at xvi. 
essence, asked his former enemies to share in the sufferings of a fellow human being, and thereby to imagine this Iroquois prisoner, and by extension all Iroquois, as included-to borrow Rorty's term-“in the range of 'us." "247

Like Rorty, the Iroquois, in practicing their unique brand of multicultural constitutionalism, recognized that increased sensitivity to the sufferings of others is a prerequisite to establishing solidarity and connection with them as fellow human beings. "Such increased sensitivity," as Rorty has written, "makes it more difficult to marginalize people different from ourselves by thinking, 'They do not feel it as we would,' or 'There must always be suffering, so why not let them suffer?' "248 We do not know precisely how much of Kiotseaeton's multifaceted message of peace was fully understood by the French at Three Rivers. We do know, however, that even the jaded Jesuit missionary Father Vimont was able to appreciate the emotive power of Kiotseaeton's performance of the sufferings endured by an Iroquois prisoner on his unescorted return to his homeland. And we may infer an increased cultural sensitivity from the provision by the French for an escort for Kiotseaeton's own return to Iroquoia.

Some of the central lessons taught by a North American indigenous vision of law and peace were evidently absorbed by the French at Three Rivers in 1645. In reflecting on the difficulties we ourselves encounter in establishing and maintaining relations with different peoples, the meanings of Kiotseaeton's dramatic portrayal of Tokhrahenehiaron's harrowing journey home can perhaps teach us important lessons as well. In a world of human diversity and conflict, relations of trust and interconnectedness require acts of imagination, by which we learn to share in the sufferings of others.

\section{Link Three: Listening Seriously to Each Other's Stories}

The Iroquois of the Encounter era never fully realized the "liberal utopia"249 of human solidarity achieved by the sharing of sufferings with others as envisioned by the contemporary philosopher Rorty. The Iroquois, according to most historical accounts, were engaged in frequent and violent wars against many of their neighbors. ${ }^{250}$ At the same time, the treaty literature does document numerous attempts by the Iroquois, such as the Treaty Council at Three Rivers, to negotiate a peace with their former enemies. Whether motivated by strategic calculations about their own survival needs, or by Deganawidah's command that the League should seek peace with other nations, or by some combination of these and other factors, the

247. Id. at 192.

248. Id. at xvi.

249. Id.

250. But see supra note 9 (discussing Iroquois cultural historiography and the distortions of Iroquois culture contained in major canonical texts by writers such as Francis Parkman). 
Iroquois frequently confronted the challenge of making peace with those who had been the cause of their own suffering, and who, in turn, had suffered at their hands.

In confronting the challenge of achieving law and peace in a world of human diversity and conflict, League diplomats could turn to the related group of stories and set narrative performances derived from the Deganawidah epic and its associated condolence rituals. In the Iroquois vision of law and peace, performance of the council rituals literally removed the barriers of suspicion, hatred, and desire for blood revenge between peoples formerly at war, so that each side could communicate the good thoughts of peace toward each other. The rich symbolic language of the stories and narratives derived from the Council thus provided Iroquois diplomats with a well-known and intensely practiced discourse by which once-alienated groups were mutually encouraged to forgive all past transgressions and enter into alhance.

Kiotseaeton relied heavily on this language in presenting his fourth wampum belt at Three Rivers. His description of the pain he suffered in passing by the spot where his kinsmen had been murdered by France's Indian allies, and the adnionishment of his dead relative to forgive his enemies, drew directly from the Deganawidah epic. Enjoining the Iroquois to value the living, the League prophet united the tribes through replacement of the mourning war tradition with the tradition of the Condolence Council. Recall, as well, the critical sequence of stories told at Three Rivers by Kiotseaeton as he presented the fifth through ninth wampum belts. ${ }^{251}$ The "words" of these belts told of how the Iroquois removed all obstructions to clear the path between the League and the French. With these "words" Kiotseaeton completed the connected set of stories derived from the Condolence Council.

The works of contemporary critical race and feminist legal scholars help us understand the use of stories and narrative techniques in the Iroquois vision of law and peace. Many of these scholars have strenuously urged the need to understand human diversity and conflict by listening seriously to the stories we tell each other, and storytelling has become an important part of their methodology in analyzing legal relations between different groups of people in our society. In a Michigan Law Review symposium issue devoted exclusively to legal storytelling, ${ }^{252}$ Richard Delgado, a leading critical race theorist ${ }^{253}$ writes that "[e]veryone has been writing

251. See supra text accompanying notes 189-99.

252. See Symposium, Legal Storytelling, 87 Mrch. L. Rev. 2073 (1989).

253. Richard Delgado has written extensively on issues of race and difference. Much of my own thinking and writing has been inspired and influenced by his many works and by our enlightening conversations over the years. Besides the Delgado source cited supra in note 175, other works of his which I have found particularly powerful and provocative include: Richard Delgado, The Imperial Scholar: Reflections on a Review of Civil Rights Literature, 132 U. PA. L. REv. 561 (1984); Richard Delgado, When a Story is Just a Story: Does Voice Really Matter?, 76 VA. L. REv. 95 (1990); Richard 
stories these days."254 In the same symposium issue, Mari Matsuda tells us that "stories are a means of obtaining the knowledge we need to create just legal structure" in a multicultural world. ${ }^{255}$ Raising consciousness by listening seriously to the stories told by others, we are told by scholars such as Delgado and Matsuda, can help us imagine the possibility of "humane social progress" and a "just world free of existing conditions of domination."256 As these contemporary scholars acknowledge, the problem of achieving law and peace in a multicultural world through storytelling requires us to understand which kinds of stories we ought to be telling to different others. Stories can connect us to others by helping us to imagine their sufferings and thereby their shared humanity with us. But stories can also exclude us from the experience of others. We may not want to listen seriously to stories which accuse us of causing the sufferings of others, particularly if we do not feel responsible for that suffering, or feel that our infliction of pain was justifled because of past actions they had committed against us. In Iroquois diplomacy, this problein of getting others to listen seriously to our stories was approached through narratives which told of forgiveness for past sufferings, and which offered to remove the barriers to communication between differing peoples caused by suspicions, hatred, and the desire for revenge. In the North American vision of law and peace, stories were used to clear the path between warring sides, revealing the warming flre of peace to former enemies.

\section{Link Four: Linking Arms Together}

The fourth link in a chain of meanings which can help us better understand the many connections between Kiotseaeton's message of peace and the problems we confront today in our multicultural world can be found in the tenth, and inost important, wampum gift presented at Three Rivers. By the "words" of this belt, the Iroquois offered to link arms together with their former enemies. ${ }^{257}$ The image of linking arms together in a treaty relationship refers to the earliest understandings of a multicultural alliance in Iroquois traditions of law and peace: two different peoples agree to join in an interdependent relationship of communication, solidarity and shared suffering. This paradigm of different peoples uniting in a continuing bond of trust and goodwill recurs throughout Iroquois diplomatic history, from the founding of the League to the formation of the Covenant Chain alliance with the English colonies.

One way to approach an understanding of this Iroquois notion of an alliance as different peoples linking arms together is to consider the increas-

Delgado, Words That Wound: A Tort Action for Racial Insults, Epithets, and Name-Calling, 17 Harv. C.R.-C.L. L. REv. 133 (1982).

254. Delgado, supra note 175, at 2411.

255. Matsuda, Racist Speech, supra note 175, at 2325 n.32.

256. Id. at 2325 (footnote omitted).

257. See supra text accompanying notes 201-08. 
ing recognition in modern American law of obligations arising out of reliance on long-term relationships. ${ }^{258}$ This expanding recognition of the reliance interest can be seen as the foundation for many of the most important insights in American legal thought during this century. Leon Green, writing in 1937 at the height of the legal realist movenient, carefully outlined the realist position that the modern market system should protect relational interests. Green, writing im the specific context of sit-down strikes, acknowledged that the industrial relation between employer and employee initially is the result of a "contractual nexus."259 But, he wrote:

as in the case of family, corporate, partnership, carrier, and all other important relations, the slender tie of the initial contract is overgrown by a network of tissue, nerves and tendons, as it were, which gives the relation its significance....

... Both groups are joint adventurers, as it were, in industrial enterprise. Both have and necessarily must have a voice in the matters of common concern. Both nust have protection adequate to their interests as against the world at large as well as against the undue demands of each other. ${ }^{260}$

Extending his analysis beyond the confines of the industrial relation between eniployer and employee, Green declared a fundamental principle which emerges throughout the works of a nuniber of major legal realists of the 1930s, as well as in the works of subsequent generations of scholars who were heavily influenced by their contributions: "All institutions built upon relational interests of the groups concerned must submit to the obligations which have grown up around the particular relation, and if it is to be destroyed it must be done subject to such obligations."261 In the 1960s and '70s, law and society scholars such as Ian Macneil and Stewart Macaulay sought to extend these insights using the empirical research tools of the modern social sciences. Their interdisciplinary work on long-term suppliers and other commercial contexts focused scholarly attention on the reciprocal legal rights, expectations, and obligations arising from various types of contractual relationships of mutuality and interdependence. ${ }^{262}$

258. As Professor Joseph Singer has described:

Many of the legal developments of the twentieth century can be described as recognition of obligations that emerge over time out of relationships of interdependence. These entitlements are neither fully articulated initially by clear state-imposed obligations nor by fully-executed and complete contracts. Rather, these obligations often are imposed to protect the interests of individuals in relying on the continuation of important relationships of interdependence.

Joseph W. Singer, The Reliance Interest in Property, 40 STAN. L. Rev. 611, 653 (1988) (footnote omitted).

259. Leon Green, The Case for the Sit-Down Strike, 90 NEw Repubuic, Mar. 24, 1937, at 199, 199.

260. Id.

261. Id. at 200.

262. On Macneil, see his works cited supra note 200. See also IAN R. Macneil, The New Social Contract: An Inquiry into Modern Contractual Relations (1980) (arguing that modem contractual relations collectively are analogous to Rousseau's concept of the Social Contract). On Macaulay, see Stewart Macaulay, Elegant Models, Empirical Pictures, and the Complexities of 
The works of several critical legal studies scholars have continued the theoretical inquiry around relational interests, focusing primarily on contract law and its connected set of doctrines. Roberto Unger, for example, has argued that focusing on trust and cooperation, rather than on the language of rights, is a better way of understanding the source and nature of many of the obligations that arise from contractual relationships of interdependence. ${ }^{263}$ Joseph Singer has sought to extend relational principles into the realm of American property law. Writing on the rights and obligations of workers and plant owners in the context of a "company town" plant closing, Singer demonstrates that Aunerican property law, like American contract law, already recognizes numerous relationships of trust, mutuality, and interdependence as property rights. Other relationships, however, such as those between plant owners and plant workers, plant and plant suppliers, and plant and town as interdependent entities supporting and sustaining each other over decades, stand for very little in the plant closing context. ${ }^{264}$

Singer's relational vision of property rights encourages us to ask a set of questions about the plant closing situation not usually considered in the language of rights in our contemporary American vision of property law:

Rather than asking "who owns the factory?" we should ask "what relationships should we nurture?" We should encourage people to rely on relationships of inutual dependence by making it possible for everyone to form such relationships and by protecting those who are most vulnerable when those relationships end. Property rights can be justified morally within a common enterprise to the extent they allow people to develop relationships that proinote conditions of trust .... [W] have an obligation to learn what it would take for us

Contract, 11 LAW \& Soc'y REv. 507 (1977) (arguing that the empirical picture of the contract process in capitalist societies differs sharply from the classical model). See also Robert W. Gordon, Macaulay, Macneil and the Discovery of Solidarity and Power in Contract Law, 1985 W1s. L. Rev. 565 (focusing on the substantial departures of Macaulay and Macneil from conventional contracts scholarship); Gidon Gottlieb, Relationism: Legal Theory for a Relational Society, 50 U. CHI. L. REv. 567 (1983) (arguing that the function of law is dependent on social context).

263. Unger, in mapping the premises of this "countervision" to the "dominant approach to contract problems" in American law, has stated:

[O]bligations do arise primarily from relationships of mutual dependence that have been only incompletely shaped by government-imposed duties or explicit and perfected bargains. The situations in which either of these shaping factors operates alone to generate obligations arc, on this alternative view, merely the extremes of a spectrum. Toward the centcr of this spectrum, deliberate agreement and state-made or state-recognized dutics bccome less important, though they never disappear entirely. The closer a situation is to the center, the more clearly do rights acquire a two-staged definition: the initial, tentative definition of any entitlement must now be completed. Here the boundaries are drawn and redrawn in context according to judgments of both the expectations generated by interdependence and the impact that a particular exercise of a right might have upon other parties to the relation or upon the relation itself.

Roberto M. Unger, The Critical Legal Studies Movement 80-81 (1986).

264. Singer, supra note 258, at 621-23; see also Local 1330, United Steel Workers v. Unitcd States Steel Corp., 631 F.2d 1264, 1266 (6th Cir. 1980) (noting that American law does not rccognize a property right sufficient to prevent United States Steel from devastating the Youngstown area by closing its plant). 
to create the kind of society in which we could trust each other enough to place our lives in each other's hands. ${ }^{265}$

The insights of the scholars of legal realism, law and society, and critical legal studies concerning the significance of interdependence and reliance in creating legal obligations can help provide a context for understanding the Encounter-era Iroquois notion of linking arms together. Although the primary purpose of Kiotseaeton's embassy to the French and their allied tribes was to secure the benefits of access to the rich fur supplies of Canada, ${ }^{266}$ the formation of an alliance based on trade signified, in the Iroquois view, the creation of an ongoing relationship of interdependence and reciprocal sharing. ${ }^{267}$ Such a partnership comprehended intangible benefits-including security, peace of mind, extension of networks of reciprocity, and shared resources in times of hardship and shortages--that transcended the immediate exchange value of traded goods.

In Iroquois diplonacy, therefore, the creation of a commercial relationship engendered ongoing reciprocal connections of trade and peace, around which various reliance interests constellated and crystallized. The Iroquois conception of these interests, as with virtually all aspects of Iroquois multicultural diplomacy, derived from the Deganawidah epic. Kiotseaeton's invitation for the French and Canadian tribes to hunt and trade in the Iroquois' territory, ${ }^{268}$ for example, echoed Deganawidah's prescription that the Five Nations, newly joined in an interdependent alliance, share their hunting grounds from which they each separately "derive their living," and thereby eat from "one dish (or bowl)."269 For the Iroquois, a treaty of trade and peace created a complex set of reliance interests in the relationship. In the Iroquois vision of law and peace, a treaty relationship meant that the two sides agreed to enter into a continuing and binding compact, encapsulated by a network of special relations with each other. Each side is to treat the other as if they were related, and the sharp dealings that might occur between strangers are replaced by the customary norms governing kinship and relations. Reciprocity and generosity are expected, and balanced exchange is spoken of as gift-giving between relatives. Reciprocation may well be delayed; kinfolk do not debase their special relationship by engaging in mere commerce. Formal exchanges, when they do occur, are accompanied by hospitality in food and lodging. Thus, although the trade in furs with the French and their allied tribes, from a non-Iroquois perspective, may have appeared to be the focal point of the negotiations at

265. Singer, supra note 258 , at 751 (footnote omitted).

266. See Iroquols Diplomacy, supra note 1, at 127-28; see also supra text accompanying notes 144-154. The Iroquois practice of seeking out intercultural trading opportunities belies the common caricature of tribal societies as lacking in concepts of "property" and market-based exchange.

267. See supra note 212 .

268. See supra text accompanying notes 210-12.

269. See PARKer, Constitution of the Five Nations, supra note 54, at 103; supra text accompanying note 212. 
Three Rivers, from the Iroquois view a more weighty framework of fundamental agreement between the two sides characterized the meeting. ${ }^{270}$

The offer to link arms together with strange and different peoples was, in effect, an offer to incorporate them into the network of connections of trust and solidarity which permeated and defined Iroquois social, political, and economic life. By bringing the French and their allied tribes under the Great Tree of Peace, the Iroquois were projecting their own internal relations of solidarity and trust across League boundaries to their new trade partners. In doing so, they were creating legal and political obligations which they understood as arising out of such interdependent relationships. In making this invitation for the French and the Canadian tribes to hunt and trade in the Iroquois' territory, Kiotseaeton expected to receive an affirmative response from the French and the Canadian tribes, in the form of a reciprocal invitation for similar hunting and trading privileges in their territories. The ongoing trade, and exchanges of hunting privileges established under the treaty, simply represented the original nexus around which the various other reciprocal obligations of the continuing relationship developed and evolved.

The prism provided by the concept of reliance interests in American law helps us understand that in the Iroquois vision of law and peace, a treaty was more than just a transient agreement to exchange a few furs for European trade goods. By agreeing to link arms together, the two sides to a treaty agreed to unite in a continuing bond of trust and solidarity. By their covenant, the two sides agreed to a mutualization of their interests, through the sharing of their hunting grounds and the resources which they acquired in making their livings. As we confront the challenges in our multicultural world of establishing relationships of trust and goodwill with peoples different from ourselves, it is useful to consider the meanings of the primary treaty belt presented to the French and their allied tribes at Three Rivers in 1645. According to the North American indigenous vision of law and peace proclaimed by the "Barbarian" diplomat Kiotseaeton, we learn what it would take to create the kind of society in which we could trust each other enough to place our lives in each other's hands, by linking arms together, and eating together out of the same bowl.

\section{CONCLUSION}

In this Article, I have tried to show how the immensely difficult problems of intercultural communication and accommodation were confronted by the Iroquois of the early North Anterican Encounter era. Through dialogic interaction, the sharing of sufferings, the clearing of barriers to communication, the reciprocal exchanges of gifts and goodwill, and the mutualization of interests and resources, different peoples could attain

270. See Marhsall D. SahLins, TRIBESMEN 81-86 (1968) (describing relations of exchange and kinship in tribal societies). 
one mind, and link arms together in a multicultural treaty relationship. I have also tried to show the commensurability of this North American indigenous vision of law and peace with the contemporary understandings of the problems of achieving human solidarity in a multicultural world articulated by a discrete set of social and legal theorists.

My intent in "linking" together what might appear initially as very different approaches to the challenge of achieving trust and cooperation between differing peoples has not been to represent that either the Iroquois of the seventeenth century, or any group of academic theorists, have developed definitive responses to this challenge. It would make for an interesting and vigorous debate to engage the question of whether the League of the Iroquois or my arbitrarily selected set of scholars, or anyone else for that matter, are closer to the truth of how human beings, in a world of diversity and conflict, agree to link arms together. Rather, my general intent has been to show that the problems of intercultural communication and accommodation are persistent features of our human experience, and that it is possible for us to come to some understanding about how peoples, distant in time and seemingly strange to us, approached these problems, using tools and methods that may make some sense from our own perspective. Such a "linking," in itself, of course, is an important part of the process by which we come to recognize our human solidarity in a multicultural world.

Thus, in discovering the meanings of a North American indigenous vision of law and peace, we come to our own understanding of the words that Kiotseaeton spoke, as he bid "adieu" to the French and the allied tribes of Canada at Three Rivers in 1645: "I am one of your relatives. I am going to carry back good news to our country."271 


\section{California Law Review}

\begin{tabular}{lll}
\hline \hline Vol. 82 & JuLy 1994 & No. 4 \\
\hline \hline
\end{tabular}

Copyright $\odot 1994$ by California Law Review, Inc.

\section{BOARD OF EDITORS}

1993-94

\author{
Editor-in-Chief \\ ANuJ R. DesaI \\ Managing Editor \\ Vivian B. DistLer
}

Senior Articles Editor

Thomas J. Peckham

Articles Editors

Nancy Combs

DAN S. SOKOLOV

Philip C. Tencer

George L. WASHington, JR.

\section{Book Review Editor}

James M. Aquilina

\section{JefF Carlisle \\ L. JAY Kuo \\ Matt LevetT \\ JENNIFER OCHS}

Fabio Arcila JR.

ERIK BABCOCK

SYlvia L. BRADdoM

ERIC DOBMEIER

Roger DOUGHTY

\section{Senior Executive} Editor

Nicole M. RyAN

Executive Editors

Steve Geary

TODd NOONAN

CAthy J. Ostiller

Production Editor JAN E. TOMSKY

Associate Editors

RICK E. RAYL

FRANK SOLOMON

RUSSELI SOMMERS

\section{Members}

Tracy Friedman DAVID E. GOLDSTEIN ANDREW HACKBERT

Craig Norris

Office Manager Karen E. Fass
Senior Notes \& Comments Editor

Frank Cialone

Notes \& Comments Editors JAMES KNOX

Flavio Rose

SARAH C. Wilson

Research \& Topics Editor Beatrice B. Nguyen

MOLLY S. STUMP

Christine H. Suh

MARSha TODD

Brian M. TORRES

Daniel Pines

ELLEN J. RubiN

DAVID W. Simon

KATHRYN E. SUAREZ

TIMOTHY J. WALSH 


\section{California Law Review}

\begin{tabular}{lll}
\hline VOL. 82 & JuLY 1994 & No. 4 \\
\hline
\end{tabular}

Copyright $\odot 1994$ by California Law Review, Inc.

\section{BOARD OF EDITORS}

1994-95

Senior Articles
Editor
STUART J. MACKEY
Articles Editors
ANDREW M. AGTAGMA
KRISTIN AMERLING
JOHN HoU
LISA M. KERR
Book Review Editor
CHRIS RILEY

Research \& Topics Editor ERIC H. WANG

\author{
Editor-in-Chief \\ Jessica M، KarNer \\ Managing Editor \\ AlICE K. MA
}

Senior Notes \& Comments Editor

JENNIFER L. GILLUM

Notes \& Comments Editors
David KING
StePHANIE POWERS-SKAFF
TUNG YIN

Associate Editors

BRETT E. CoOpER

JOSEPH E. JARAMILLO

AISHAH SMITH

Production Editor

Thu Trâm T. PhI

Senior Executive
Editor
ABRIL R. BEDARF

Executive Editors

EDWARD L. ADAMS

Michelle M. LEMLEY

Chun PoK Leung

BURKE F. NORTON

Senior Production Editor

MARIA V. RECALDE-BERNSTEIN

\section{Members}

Melissa A. Dawson DOUGLAS K. DORST Michael S. Joaquin ELIzABETH J. LeVENSOHN Michael D. Lewis

Kerne Matsubara JEFFREY L. MENGOLI Peter W. POULOS Matthew F. Roberts

Office Manager KAREN E. FAsS
Sean Rodgers KulPREET Singh NANCY A. Solotkin SCOTT TACHIKI SUSIE TER JUNG 